\title{
WestVirginiaUniversity
}

THE RESEARCH REPOSITORY @ WVU

Graduate Theses, Dissertations, and Problem Reports

2012

\section{Bringing Pragmatics into the ESL Classroom}

Tahnee Bucher Barbosa da Silva

West Virginia University

Follow this and additional works at: https://researchrepository.wvu.edu/etd

\section{Recommended Citation}

Bucher Barbosa da Silva, Tahnee, "Bringing Pragmatics into the ESL Classroom" (2012). Graduate Theses, Dissertations, and Problem Reports. 316.

https://researchrepository.wvu.edu/etd/316

This Thesis is protected by copyright and/or related rights. It has been brought to you by the The Research Repository @ WVU with permission from the rights-holder(s). You are free to use this Thesis in any way that is permitted by the copyright and related rights legislation that applies to your use. For other uses you must obtain permission from the rights-holder(s) directly, unless additional rights are indicated by a Creative Commons license in the record and/ or on the work itself. This Thesis has been accepted for inclusion in WVU Graduate Theses, Dissertations, and Problem Reports collection by an authorized administrator of The Research Repository @ WVU. For more information, please contact researchrepository@mail.wvu.edu. 


\title{
Bringing Pragmatics into the ESL Classroom
}

Tahnee Bucher Barbosa da Silva

\author{
Thesis submitted to the \\ Eberly College of Arts and Sciences \\ at West Virginia University \\ in partial fulfillment of the requirements \\ for the degree of
}

Master of Arts in

TESOL

\begin{abstract}
Xiangying Jiang, Ph.D., Chair
Ahmed Fakhri, Ph.D.

Huey Hannah Lin, Ph.D.

Department of World Languages, Literatures, and Linguistics
\end{abstract}

Morgantown, West Virginia

2012

Keywords: Pragmatics; ESL Learners; Teaching and Assessing L2 Pragmatics Copyright 2012 Tahnee Bucher Barbosa da Silva 


\section{ABSTRACT \\ Bringing Pragmatics into the ESL Classroom}

Tahnee Bucher Barbosa da Silva

As a result of the expanding interest in the cognitive and social dimensions of language use beyond single sentences, a great number of research studies have been conducted in order to examine nonnative speakers' ability to use language appropriately in a social context. Recently, with a growing understanding of the key role pragmatic competence plays in second language development, researchers have also investigated the benefits of direct instruction in helping language learners become aware of the pragmatic conditions governing the uses of grammatical structures. This thesis reports on the design and administration of a study that investigated language learners' knowledge of pragmatics and how instruction can help them develop this knowledge in an environment where English is taught as a second language. Specifically, this project had two aims: (1) to observe the relationship between language proficiency and pragmatic competence of learners of English as a Second Language (ESL), and (2) to examine whether instruction was effective in improving those learners' pragmatic knowledge. Pragmatic competence was measured quantitatively, through discourse judgment tasks, multiple-choice discourse completion tasks (MDCTs) and written discourse completion tasks (WDCTs) in a pre-, post-, and delayed post-test, designed specifically for this study. The participants in this research, thirty-nine adult ESL learners with a range of proficiency studying in the Intensive English Program (IEP) and in a university-level English course at West Virginia University, first took a language proficiency test and a pre-test on pragmatic knowledge. The participants were then assigned into two groups, experimental and comparison. The experimental group received four hours of direct instruction in five types of speech acts (requests, refusals, apologies, compliments, suggestions) and other aspects of pragmatic knowledge over a period of two weeks, while the comparison group was taught lessons on other topics without intervention during the same amount of time. An immediate post-test on pragmatic knowledge and a delayed post-test were given to both groups. The results showed that language proficiency and pragmatic knowledge were positively correlated with a moderate strength $(r=.71, p<.001)$. Analysis of covariance and further analysis showed that the experimental group significantly outperformed the comparison group in both the post-test and delayed post-test. The experimental group benefited from the instruction, which used a blended methodological approach, and the instructional effect was retained after a one-week delay. The results of this research helped understand the communicative skills and intercultural competence of ESL learners and demonstrated that instruction in the area of pragmatics is not only important but it can be beneficial at all levels of language proficiency. It is hoped that the topics reported and discussed here and the findings may help both English as a Foreign Language (EFL) and ESL teachers gain a better understanding of second language learners' pragmatic competence and development through instruction, so that when they incorporate pragmatics instruction into their teaching, they will be in a better position to adapt their practices to facilitate pragmatic development. 


\section{Dedication}

This thesis is dedicated to my family and to my former, present, and future students. 


\section{Acknowledgments}

It is a pleasure to thank all of those who supported me in any respect during the completion of this project. First and foremost, I would like to thank my committee members, who guided me and without whose support, advice, and expertise, this thesis would not have been made possible. Dr. Xiangying Jiang, my thesis advisor and chair of the committee, for her invaluable support, guidance, and encouragement, and for all the effort put into this thesis. Thank you for guiding me through the thesis writing process inside and outside of class, and for teaching me the building blocks that resulted in this thesis: research methods, second language acquisition theory, and language assessment. I would also like to express my sincere gratitude for being understanding and patient. Dr. Ahmed Fakhri, who first introduced me to the pragmatics area of language teaching in his Discourse Analysis class during my first semester at West Virginia University, and Dr. Huey Hannah Lin, who trusted my work and promptly accepted to be part of my committee. I highly value your insightful comments, encouraging feedback, and your help with this thesis.

I owe my deepest gratitude to Stacy S. Fint, the Intensive English Program Director. Without her support this project would, literally, not have been possible. Thank you for offering me the opportunity to teach in the IEP, for always believing in my work, and for allowing me to conduct my research there. I also deeply appreciate the help of all IEP staff, particularly all the instructors and Graduate Teaching Assistants, who advertised and got students involved in this research project. A heartfelt thanks goes to all the students who participated in this project and dedicated eight extra hours in their already busy schedule to help me with it.

I also wish to thank Dr. Susan Braidi, my academic advisor in the Master’s Program, and Dr. Sandra Stjepanovic, Graduate Programs Coordinator, for providing a lot of early advice and 
encouragement and for helping me navigate life as a master's student as smoothly as possible. I would also like to thank Dr. Angel Tuninetti, Chair of the World Languages, Literatures, and Linguistics Department, for his support, comprehension and for giving me the opportunity to extend my studies, and Dr. Sandra Dixon, the Portuguese Program coordinator, for her kind words and encouragement throughout this process.

I could never have finished this thesis without the continuous support and friendship of my M.A. classmates and colleagues in Morgantown, particularly Livia Cascão, Timothy Hutchinson, Deborah Lyra, Michael Morris, Lindsei Pereira, and José Pinto de Moura Junior. Thank you for your interest and input in my research project. Thank you for helping me with advertisements and for proctoring and grading the tests, especially when I knew you had a lot to do for your own courses. Mostly, however, I would like to thank you for all the experiences we shared, through amazing and also difficult times, the inspirational quotes that got us all through the day, and the stimulating discussions about everything possible - from pragmatics to language variation, geography, students, zombie attacks, and workout routines (not for me, of course). Many thanks for always going above and beyond to cheer me up, help me out, to not allow me to be so OCD, and for being there when I was completely stressed out. I will always remember our dinners together, our beers and singing on the porch, our bonding conversations, and all the Arnold Schwarzenegger movies. Mike and Tim, I could not be more grateful for being the third Musketeer.

I would also like to thank Karla Assis, one of my professors at UFES (Federal University of Espírito Santo) who encouraged me to apply for the Master’s Program at WVU, and Maria Lisa Dunn and George Lies for accepting me in the Council of International Programs and being the ones who opened the doors for me here at WVU. 
I would like to thank my parents, Ivelise Bucher and Sebastião Barbosa da Silva Filho, for their love, care, and support sent from far away throughout those three years. Thank you for believing I could live the life I had imagined. I wish to thank my stepmother, Fabiola Assad, for always helping me make better decisions. I would also like to tell my 3-year-old brother, Felipe Antunes, I’m so sorry for not being there to see you grow up, learn how to walk and speak, and for not being able to spend more time being Wendy and Captain Hook when you were always Peter Pan. Being away from you is what made these three years the most difficult ones in my entire life, but keeping you always in my heart and in my mind couldn’t have given me greater joy.

Betsy Pyle, James Shumway, and Wesley Shumway, I can’t find the right words to express how lucky I am for having you as my American family. Thank you for literally making Morgantown my home away from home. It is an honor for me to be your Brazilian daughter.

I would also like to thank all my family and friends in Brazil, in the United States, and in other parts of the world, and my boyfriend, Thomas Ryan Ponzurick, for his support and for always reminding me to take a deep breath and keep on track.

Thank you very much. Muito obrigada. This dream would have never come true without all of you. 


\section{Table of Contents}

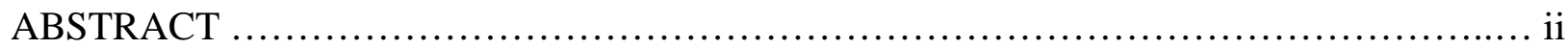

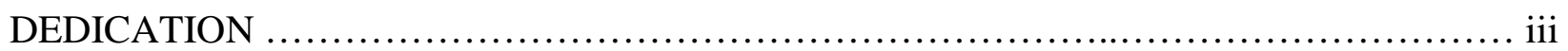

ACKNOWLEDGMENTS........................................................... iv

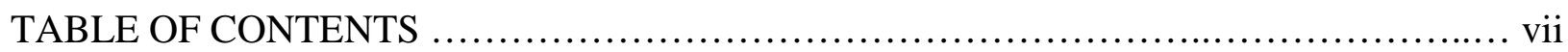

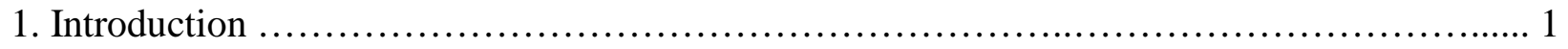

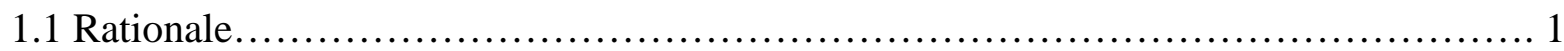

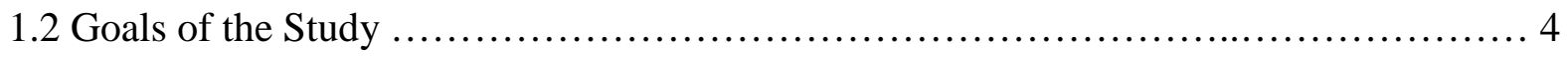

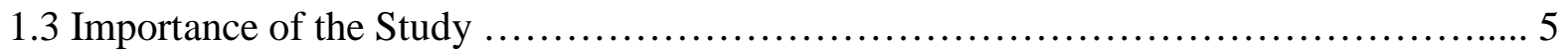

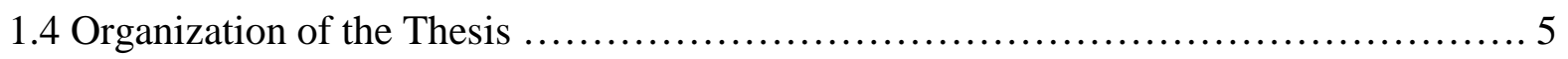

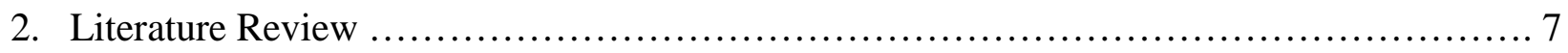

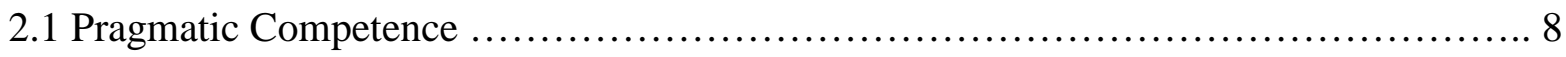

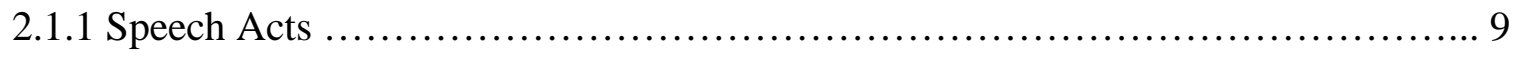

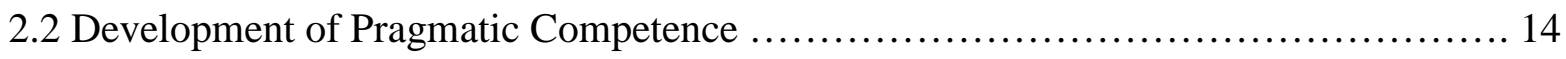

2.2.1 Language Knowledge and Pragmatic Competence ......................... 14

2.2.2 First Language Influence in L2 Pragmatic Development ..................... 16

2.2.3 The Role of the Environment in Pragmatic Instruction ........................18

2.2.4 Types of Instruction Methods ....................................... 20

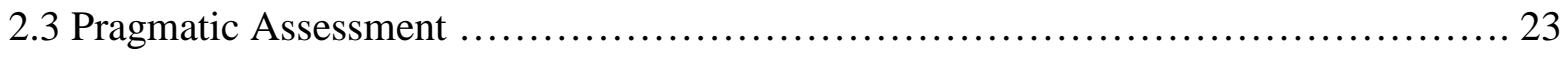

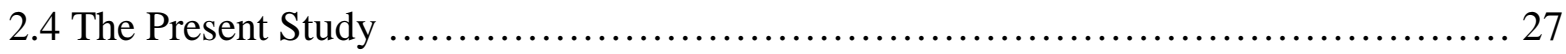

3. Methodology ................................................................ 29

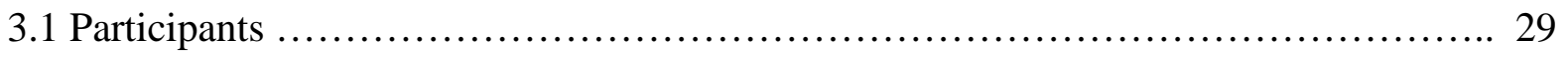

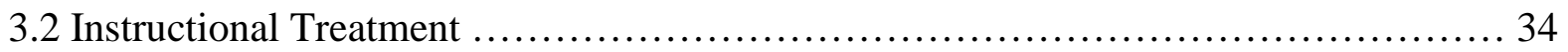


3.2.1 Experimental Group (Group A) ….................................... 34

3.2.2 Comparison Group (Group B) ….................................... 38

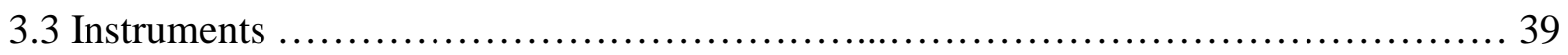

3.3.1 Language Proficiency Test ............................................... 39

3.3.2 Pragmatics Tests ..................................................... 41

3.4 Data Collection Procedures ...................................................... 45

3.5 Data Analysis ................................................................... 47

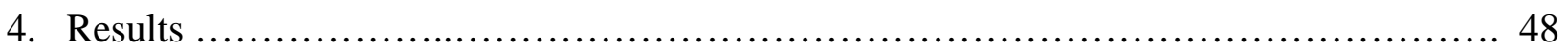

4.1 ESL Learners’ Awareness of Pragmatics ....................................... 48

4.2 Language Proficiency and Pragmatic Competence ................................... 49

4.3 Instructional Effectiveness in an ESL setting ...................................... 49

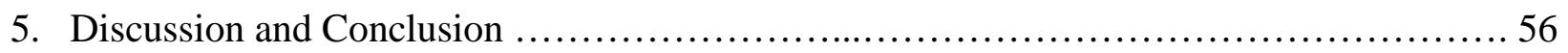

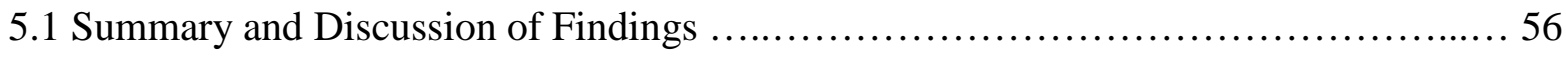

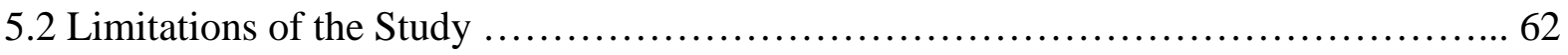

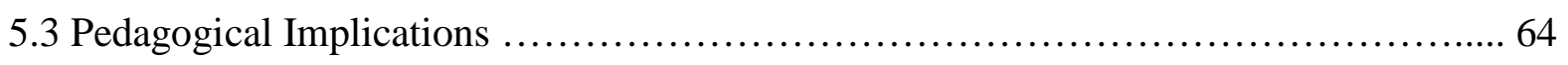

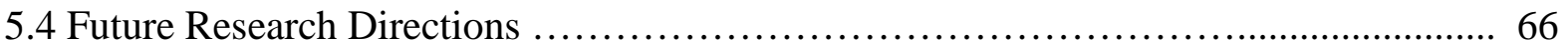

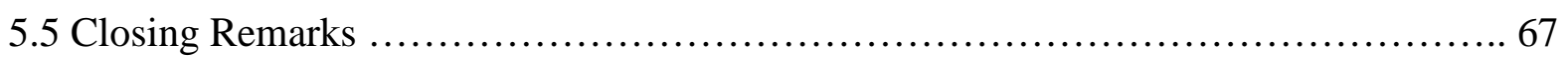

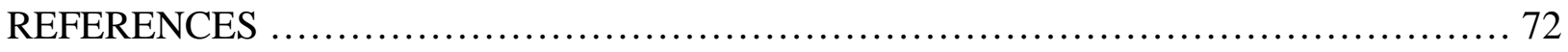

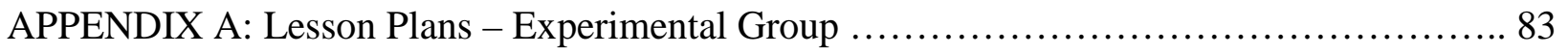

APPENDIX B: Sample Lesson Plan - Comparison Group .................................. 105

APPENDIX C: Participant Questionnaire …..................................... 108

APPENDIX D: Language Proficiency Test ............................................... 109

APPENDIX E: Language Proficiency Test Answer Key .................................... 119 
APPENDIX F: Table of Specifications - Pragmatics Tests ........................ 120

APPENDIX G: Pragmatics Tests .................................................. 121

APPENDIX H: Pragmatics Tests Answer Key ....................................... 139

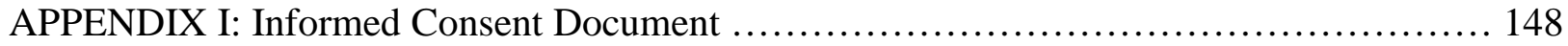

APPENDIX J: Sample Syllabus .............................................. 152 


\section{Introduction}

\subsection{Rationale}

The history of second language instruction shows different perspectives and approaches to teaching, each trying to be a major improvement over the previous ones. In the mid-1970s, a shift from focus only on isolated grammatical forms to focus on language as a vehicle for communication meant that students needed to acquire knowledge to be able to comprehend and produce meaning in context. Thus, teaching a language entailed more than just teaching its sound systems, syntax, morphology, lexicon, and semantics. Second language learners needed also to know pragmatics, or "the way in which we use language in context” (Gass \& Selinker, 2008, p. 13) in order to become communicatively competent in a second language.

This approach is supported by Bachman’s (1990) language competence model, in which language competence is divided into organizational competence (knowledge of linguistic units at the sentence level and discourse) and pragmatic competence (knowledge of speech acts and speech functions and ability to use language appropriately according to context). This implies that a proficient speaker knows not only the linguistic forms to perform a language function (e.g., greetings or leave-takings), but also the contexts in which these forms are used.

In fact, the ability to do this is crucial to communicating effectively: failure to do so may cause cross-cultural miscommunication or cultural stereotyping. Second language speakers, for example, may be perceived as rude if they are not aware of the sociolinguistic rules governing language use (e.g., what to say to whom and when). As Blum-Kulka, House, and Kasper (1989, p. 10) note, “Even fairly advanced language learners’ communicative acts regularly contain pragmatic errors, or deficits, in that they fail to convey or comprehend the intended illocutionary force or politeness value [of utterances].” 
Bardovi-Harlig (1996) further states that "language learners have difficulty in the area of pragmatics, regardless of their level of grammatical competence” (p. 21). This means that one cannot take for granted that the more developed the four skill areas (reading, writing, speaking, and listening) are, fewer errors will be made concerning language use. Students will not know how to act appropriately just by learning the linguistic forms and functions of a language (for example, just telling them that one modal verb entails more politeness than the other). Learners might also use the target language based on the norms of behaving (and interpreting social behavior) of their first language. As with linguistic forms, interference from the native language can occur with pragmatic knowledge as well.

Recent studies in interlanguage pragmatics indicate the need of teaching second language learners the pragmatic conditions governing the use of grammatical structures, mainly because they might not perceive the mismatch between the pragmatic rules of their native language and those of the second language. As LoCastro (2003) emphasizes, "teachers now have to teach how to speak the second language and to train learners to use it in situationally appropriate ways” (p. VIII).

However, pragmatic and sociolinguistic rules of language use still are areas underemphasized in language courses and textbooks, even though there is "expanding interest in the cognitive and social dimensions of language use beyond single sentences” (LoCastro, 2003, p. VIII). Vellenga (2008) points out some reasons why there is a lack of pragmatics instruction at any level: "the sheer volume of subject material to be taught when teaching a second language, feelings that students will somehow just 'pick it up', unfamiliarity with appropriate teaching methods (lack of training) or unwillingness on the part of instructors to teach pragmatics” (p.1). 
Even though there are many challenges involved in teaching pragmatics, instruction in this area has been strongly encouraged based on the assumption that raising students’ pragmatic awareness and giving them opportunities to practice can contribute to the development of their communicative competence. Kasper and Schmidt (1996) affirm that "there is every reason to expect that pragmatic knowledge should be teachable” (p. 160). Along with this view, other research studies have demonstrated the benefits of instruction in helping language learners become aware of the pragmatic conditions governing the uses of grammatical structures (Bardovi-Harlig, 1996; House, 1996; Kasper \& Schmidt, 1996; Martínez-Flor \& Soler, 2007; Takimoto, 2008).

Most studies, however, have focused on EFL learners and the effects of instruction in foreign language classrooms mainly because students in this setting are not sufficiently exposed to authentic language use (Jeon \& Kaya, 2006), as opposed to ESL students who are learning the second language in an environment with considerable access to speakers of that language. This focus on EFL learners may be explained by the assumption that ESL learners’ pragmatic competence is more developed due to their environment and, thus, instruction would not be made necessary. Even though this comparison between ESL and EFL learners might be true, ESL learners are not native speakers either, and they still have problems in interpreting meaning and expressing themselves in the target language. In addition, because they are inserted in an environment where the target language is spoken, the need to communicate appropriately is more urgent than in an EFL setting. 


\subsection{Goals of the Study}

This thesis investigates language learners' knowledge of pragmatics and how instruction might help them develop this knowledge in an environment where English is taught as a second language (ESL). Specifically, this project had two aims. The first one was to examine whether language proficiency is related to the pragmatic competence of ESL learners. Based on results of previous research studies (e.g., Bardovi-Harlig, 1996; Blum-Kulka, House, \& Kasper, 1989), it was hypothesized that the pragmatic competence of these learners would not be concomitant with their language proficiency; specifically, even learners with high language proficiency would still make pragmatic errors.

The second aim of this project was to examine whether instruction was effective in improving those learners’ pragmatic competence. In order to achieve this goal, the participants in this study were divided into two groups, experimental and comparison. The latter was taught communicative lessons without any intervention, while the former received the instructional treatment, which consisted of activities aimed at developing students' awareness of pragmatic aspects of language use, recognition of pragmatic infelicities, and ability to produce pragmatically appropriate language.

Because this study of instruction in pragmatics dealt specifically with comprehension and production of five speech acts (requests, refusals, apologies, compliments, and suggestions), the assessment instruments were designed to quantitatively measure students' pragmatic competence in terms of their ability to recognize pragmatic infelicities, comprehend and produce the speech acts mentioned above. 


\subsection{Importance of the Study}

This study can contribute to the increasing body of research on instructed pragmatics by providing detailed description of assessment of pragmatic ability and of an instructional treatment to learners in an ESL setting, and by offering supporting evidence for the importance of instruction in pragmatics. The uniqueness of this study stems from a number of factors, mainly the focus on both comprehension and production of socially appropriate language, the use of a variety of elicitation procedures, and the administration of pre-, post-, and delayed post-tests to students of different levels of proficiency and from a variety of native language backgrounds. The findings can also contribute to a better understanding of ESL learners' interlanguage pragmatic development and pragmatic knowledge and, ultimately, to the development of teaching materials that include pragmatics instruction in order to increase second language learners' communicative skills and intercultural competence.

\subsection{Organization of the Thesis}

This thesis consists of five chapters. Chapter 1 situates the study, introduces the issues and the goals of this research project, and explains the importance of the study. Chapter 2 is a literature review that provides a historical background of pragmatics research, including a description of the relevant SLA (Second Language Acquisition) methodologies incorporated into the development of the assessment instruments, the materials used, and the instructional treatment. This chapter also explains the theoretical foundations of the speech acts selected for this study and presents the research questions. 
Chapter 3 describes the methodology used in this study, including a detailed description of the participants, materials and instruments, training, data collection, scoring procedures, and data analysis.

Chapter 4 presents the results of the study, including answers to the research questions. Chapter 5 summarizes and discusses the main findings of the study, discusses limitations, proposes directions for future research, and provides closing remarks. 


\section{Literature Review}

As a result of the expanding interest in the cognitive and social dimensions of language use beyond single sentences, a great number of research studies have been conducted in order to examine nonnative speakers’ ability to use language appropriately in a social context and how they develop the ability to do so. However, even though pragmatic competence has long been considered a crucial part of linguistic competence (Bachman, 1990; Canale \& Swain, 1980; Hymes, 1972), only recently researchers have started to further investigate three specific areas of L2 pragmatics: 1) How knowledgeable about pragmatics language learners are; 2) how teachers can help students develop pragmatic competence (by examining the effects of different types of instruction in helping language learners become aware of the pragmatic conditions governing the uses of grammatical structures); and 3) how pragmatic proficiency can be assessed (Cohen, 2004; Rose \& Kasper, 2001).

In order to provide an overview of the relevant research underlying the rationale behind the current study, this chapter first defines the construct of pragmatic competence, including the theoretical foundations of the speech acts selected for this study. It continues with a discussion of the development of pragmatic competence, exploring the relationship between language proficiency and pragmatic competence and first language influence in L2 pragmatic

development. The role of the environment in pragmatic instruction is then examined, followed by a review of research articles that investigate the effects of different types of instruction available and by a summary of the instruction methods incorporated in this study. The chapter concludes with a discussion of the methodologies used to assess pragmatic competence and provides the research questions that guided this present study. 


\subsection{Pragmatic Competence}

Pragmatic competence refers to the ability to use language in socially appropriate ways and to interpret both implicit and explicit meaning according to context (Thomas, 1995). Since the mid-1970s, when the overall goal of language teaching and assessment shifted to a focus on developing learners’ communicative competence, knowledge of the pragmatics aspects of language use has been proven necessary, along with linguistic knowledge, to enable students to become proficient in the target language.

As Taguchi (2003, p. 16) puts it, pragmatic knowledge “deals with language use in relation to language users and language use settings.” A speaker who has pragmatic competence knows, therefore, how to create and interpret utterances bearing in mind the language user's intentions and the setting in which a particular sentence is being uttered. This basically suggests that pragmatic knowledge must encompass then two different types of knowledge. Leech (1983) and Thomas (1983) proposed that pragmatics should be divided into two components pragmalinguistics and sociopragmatics - in order to account for how people accomplish goals, get things done, and convey meaning (whether implicit or explicit) with words in a particular setting. The first refers to pragmatic strategies such as the use of semantic formulae, routines, and linguistic forms that can serve the purpose of making the communicative act more direct or indirect, softer or more intensified. Sociopragmatics is related to social behavior, and the way speakers in a certain community interpret and accomplish a communicative act. As Leech (1983) points out, pragmalinguistics is more related to the linguistic/grammatical aspects of a language, while sociopragmatics is driven more towards the socio-cultural end of pragmatics.

Bachman (1990) supports this approach and describes language ability broadly as "the ability to use language communicatively” (p. 81). He proposed a model that was mainly 
comprised of two elements: language knowledge and strategic competence. Language knowledge is then understood as consisting of "organizational knowledge" and "pragmatic knowledge.” The pragmatic knowledge he refers to considers the appropriateness of a particular communicative goal (what he calls "functional knowledge") and the appropriateness of the language use setting (“sociolinguistic knowledge”). Bachman and Palmer later revised this model, but the prominence of pragmatic ability was kept (1996), and their notion that pragmatic knowledge involves the relationship between utterances, language users, and settings supports the views of well-known researchers in the field that came before them (e.g., Thomas 1983, 1995; Leech, 1983; Levinson, 1983; Mey, 1993).

Crystal (1985, p. 240) defines pragmatics as "the study of language from the point of view of users, especially of the choices they make, the constraints they encounter in using social interaction and the effects their use of language has on other participants in the act of communication.” Following Crystal’s $(1985,1997)$ definition of pragmatics, Rose and Kasper (2001, p. 2) expand the notion of communicative ability and summarize the study of pragmatics as "the study of communicative action in its sociocultural context." Communicative action takes place not only when one engages in different types of discourse encountered in social situations (which vary in length and complexity depending on the degree of familiarity between interlocutors, differences in social status, and degree of imposition), but also when speech acts (such as requests, refusals, apologies, compliments, and suggestions) are used.

\subsubsection{Speech Acts}

Pragmatics is concerned with authentic language use, and thus teaching pragmatics means addressing issues of language use in the classroom. Rose (1997, p. 126) compiles some 
areas of knowledge that learners should acquire in order to become pragmatically fluent in an L2, such as “knowledge of language functions” (Wilkins, 1976), “speech acts” (Austin, 1962; Searle, 1969), “Gricean conversational maxims” (Grice, 1975), “principles of linguistic politeness” (Brown \& Levinson, 1987), “conversational style” (Tannen, 1984), “conversational management” (Goffman, 1976; Sacks et al., 1974). Out of those areas, however, speech acts have been the most widely researched aspect of language use and a great number of pragmatics empirical research studies investigate the comprehension and production of speech acts by nonnative speakers and in some cases, compare and contrast to native speakers’ performance.

Speech Act theory was developed by Austin (1962), a philosopher of language who argued that language is used to carry out actions - how to do things with words. It comes from the notion of what he called performative verbs, which explicitly indicates the speaker's goal as it is uttered. Examples would include "I promise to meet you next Monday" or "I pronounce you husband and wife.” Austin first categorized five classes of speech act types, i.e., verdictives, exercitives, commissives, behabitives, and expositives. Later, another philosopher of language, Searle (1975), modified Austin’s model and classified the speech acts into representatives, commissives, directives, expressives, and declarations. Basically, speech acts categorize language functions such as thanking, requesting and refusing, apologizing, complaining, giving advice, complimenting, among others.

The majority of studies that investigate learners’ pragmatic awareness and the effects of instruction have focused on requests (e.g., Carrell \& Konneker, 1981; Kitao, 1990; Olshtain \& Blum-Kulka, 1985; Tanaka \& Kawade, 1982), refusals (Soler \& Pitarch, 2010; Vellenga, 2008), apologies (Olshtain \& Blum-Kulka, 1985), and suggestions (Koike, 1996; Jiang, 2006; MartínezFlor \& Soler, 2007). Cohen (2008) suggests that one of the reasons that generated a considerable 
amount of research in the area of speech acts is due to the apparent mismatch between the propositional meaning of a speech act and its intended illocutionary meaning. He cites the example of a request, which is often made indirectly, as in the question "Do you have a watch?" and does not mean literally that the speaker wants to know whether the other person owns a watch. In reality, the meaning intended by the speaker is most likely that he/she wants to know what time it is. When the hearer fails to comprehend this actual illocutionary force and, in this example, answers "Yes, I do", miscommunication arises and can cause problems of a lesser or greater extent depending on the situation.

A speech act perspective is a way of viewing pragmatics, and contrastive analysis has demonstrated that learners differ from native speakers (NSs) in the production of speech acts in different ways (Blum-Kulka, 1982; Cohen, 1996). Bardovi-Harlig (1996) identified four main categories in which learners differ from NSs: choice of speech acts, semantic formula, content, or form. Even when learners choose the appropriate speech act, they might not use the right formula and give enough information (content). For example, an apology is usually followed by a reason or an excuse that fits the situation, an offer to compensate the person for the problem, and/or a promise to change, or not let something happen again. Thus, a non-native speaker might simply say "I'm sorry, I didn't have time to finish my homework," but not recognize that he/she should add more steps (the compensation and the promise) to the performed speech act. Similarly, non-native speakers might choose the appropriate speech act, but use the wrong form. A longitudinal study of pragmatic development conducted by Bardovi-Harlig and Hartford (1993) that set out to explore the way native speakers differ from non-native speakers in the production of speech acts in academic advising sessions found out that learners used aggravators 
that native speakers never did, and that they often didn't use the mitigators used by their native speaker peers.

The five speech acts selected for this study, namely requests, refusals, apologies, compliments, and suggestions, were chosen based on the fact that they are well represented in cross-cultural and interlanguage pragmatics literature, both in theoretical as in pedagogical terms. The inclusion of this relatively wide variety of speech acts was intentional so that students would be exposed to situations that differ not only in terms of conventionality and frequency (requests, for example, are more conventional and more frequent than refusals), but also in terms of interlocutor roles (initiator vs. responder) and degrees of imposition (e.g., status differentials).

It would be erroneous to admit, though, that only by looking at second language learners’ ability to comprehend and produce speech acts, one could judge their overall pragmatic fluency. As mentioned before, pragmatics involves much more than just speech acts. Vellenga (2008, p. 16), reinforces this idea by pointing out that “for learners, understanding pragmatics involves knowing which form to select from a repertoire of possible linguistic choices to express the appropriate illocutionary force as well as perform the desired speech act function.”

Another criticism of the speech act theory is the fact that no instructional order has been specified (Flowerdew, 1990). While generative grammar claims that there is an order of acquisition, no such claims were made by speech act theory. It is important to notice, though, that within a particular speech act some strategies are learned first. For example, non-native speakers learn how to make direct requests before conventionally indirect requests (Kasper \& Schmidt, 1996). Flowerdew (1990) also points out other potential problems with speech act theory that can be of concern to pragmatics instruction. For instance, the large number of speech acts and "the relation between the whole and the parts in a discourse” (p. 79). First, it is virtually 
impossible to teach all speech acts found in every language context and purpose, and second, speech acts are minimum communication units that can't just be only analyzed at a sentence level. In fact, other analyses that have been made based on speech act theory, such as Brown and Levinson's (1987) analysis of politeness strategies, have also been criticized for focusing on units at the sentence level instead of the discourse-level. As Lin (2005, p.4) points out, "little research has examined politeness strategies in a speech event where various speech acts are embedded." She further suggests that, in order to investigate how the context affects speakers' choices of politeness strategies, one should look not only at the "global context, i.e., the cultural, social, and situational" but also at the "local context, i.e., previous utterances in the on-going sequences of a conversation” (p. 161). She emphasizes the importance of analyzing the utterances in longer stretches of discourse, and not in isolation, in order to be able to understand the politeness strategies chosen by the speakers.

Nonetheless, operationalizing the construct of speech acts is relatively easy, compared to, for example, operationalizing "politeness". Being polite does not necessarily mean that successful communication has taken place, because a speaker may very well choose not to be polite and still be able to accomplish his/her goal. Thus, it is easier to observe and measure the accuracy of comprehension and production of speech acts than to determine the contextual situation in which a speaker would choose to be polite or rude. Furthermore, the purpose of teaching pragmatics in the classroom is not to teach students how to be polite or to sound like a native speaker when speaking a foreign language, but rather to give them the linguistic tools so that they are able to make conscious choices about how they want to sound in that particular language. Instructional pragmatics is about making students aware of how things are accomplished in the L2 and teaching the linguistic choices that are available in order to enable 
them do so. Second language speakers, as well as native speakers, should be able to decide to be polite or rude in a specific situation - intentionally, not accidentally (Grant \& Starks, 2001).

\subsection{Development of Pragmatic Competence}

An increasing number of research studies have examined the development of L2 learners' pragmatic ability from a variety of theoretical perspectives (cf. reviews by Bardovi-Harlig, 1999; Kasper \& Rose, 1999; Kasper \& Schmidt, 1996). Some of the approaches to interlanguage pragmatics will be presented in the next subsections due to their particular relevance to this present study. The first one focuses on the relationship between pragmatic ability and language knowledge, while the second one looks at the influence of learners' native language in L2 pragmatic development. The L2 learning environment and the types of instruction methods have also been found to play a key role in the development of pragmatic competence, and will thus be discussed in the last two subsections.

\subsubsection{Language Knowledge and Pragmatic Competence}

In 1996, Bardovi-Harlig argued that even high proficient learners encountered difficulty in the area of pragmatics, that is to say, their pragmatic ability was not concomitant with their level of grammatical competence. Three years later, she added that "although grammatical competence may not be a sufficient condition for pragmatic development, it may be a necessary condition” (p. 677). For instance, some forms associated with politeness are more grammatically complex (e.g., use of verbs in the past tense for a request), so that learners need more mastery of the L2 in order to perform certain pragmatic functions (Trosborg, 1995). If students only know one linguistic form to accomplish a pragmatic function (e.g., imperatives for requests, or direct 
expressions such as “I can't” for refusals), they are not really making a pragmatic decision, but rather just using the L2 linguistic form they have available (Bardovi-Harlig, 2002a; Vellenga, 2008). Thus, if second language learners have a wider range of linguistic resources to draw from, they are already in a better position to accomplish communicative goals more successfully. The following studies provide good evidence for this statement.

For example, Takahashi and Beebe’s (1987) study of written refusals show that advanced learners used a greater range of intensifiers, such as 'truly', 'deeply', 'extremely'. This is also an evidence of how lexicon development influences the way nonnative speakers convey their intended meaning. Besides that, the fact that lower-level learners used more direct expressions such as 'I can't' when making refusals might not be related to their first language norms, but rather to a developmental stage in which learners rely on simpler and more direct expressions because they haven’t learned and/or mastered more sophisticated linguistic forms.

One of the findings of a study conducted by Maeshiba, Yoshinaga, Kasper, and Ross (1996) was that higher-proficiency learners used more downtoners, understaters, hedges, subjectivizers, intesifiers, and commitment upgrades than lower-proficiency learners. The researchers noted that "it is difficult to say whether this pattern truly reflects a development of pragmalinguistic competence or merely an extension of the learners’ lexical repertoire” (p. 160).

There seems to be the case that it is necessary for learners to have mastered some basic linguistic skills before they can start making pragmatic choices. Jeon and Kaya (2006, p. 182), suggest the existence of a linguistic threshold: “within the instructed L2 pragmatics research community, it is implicitly believed that a linguistic threshold is required for the acquisition of L2 pragmatics.” 


\subsubsection{First Language Influence in L2 Pragmatic Development}

Kasper and Schmidt (1996, p. 160) affirm that "there is every reason to expect that pragmatic knowledge should be teachable.” Supporting that view, many pragmatics researchers well-known in the field agree that instruction plays a role in making learners aware of the pragmatic rules governing the use of the L2 and in helping them acquire pragmatic fluency (Bardovi-Harlig, 1999; Bardovi-Harlig \& Griffin, 2005; Bialystok, 1993; Cohen, 2005; Hinkel, 2001; Kasper \& Schmidt, 1996; LoCastro, 2003; Martínez-Flor \& Usó Juan, 2006; Rose, 1997; Rose \& Kasper, 2001). However, advocating instruction in the area of pragmatics does not imply that second language learners would not acquire L2 pragmatics without any type of intervention, and neither does it imply that all L2 pragmatics knowledge can be teachable or should be taught in every learning environment. One of the reasons is that some pragmatic knowledge is universal (e.g., Blum-Kulka, 1991; Ochs, 1996) and other aspects may be successfully transferred from the learners’ L1.

As learners move towards proficiency and gain greater awareness of the linguistic forms to perform speech acts or other speech functions, they often encounter influence from their first language. Such influence is called transfer, and it can be positive or negative. In other words, when learning a second language, students bring into the process from their first language not only their linguistic knowledge but also the norms of interpreting and behaving in social situations. Kasper and Schmidt (1996, p. 154) offer more evidence that "there are some pragmatic universals underlying cross-linguistic variation," such as the use of indirectness to convey pragmatic intent and the use of different linguistic forms depending on contextual constraints. Furthermore, a basic set of speech acts can be found in any linguistic community and thus positively influence the realization of second language speech acts. Pragmatics 
instruction becomes particularly useful when it comes to not only making students aware of how certain speech acts are accomplished in their L1 and in their L2, but also giving them linguistic choices in order to avoid negative transfer and the possibility of miscommunication.

In order to investigate the nature of transferability, Takahashi (1993) examined the production of indirect requests by thirty-seven female Japanese speakers of English in four situations. The subjects - beginning/intermediate and highly advanced - undertook an acceptability judgment task for five indirect request expressions in Japanese and English, respectively, for each situation. All the situations involved asking something difficult for a notso-familiar, older female neighbor, belonging to a higher status, to do. The researcher hypothesized that the language-neutral "want statement” ("I would like you to open the window”) and “willing statement” (“Would you open the window?”) would be relatively transferrable to the corresponding English request context. In addition, the "mitigated ability statement” (“I wonder if you could open the window”) and the "mitigated expectation statement” (“I would appreciate it if you could open the window") would be relatively non-transferable to the corresponding English request context. The results indicate the transferability of the indirectness strategies are primarily related to contextual factors, as each indirectness strategy manifested differences in terms of transferability determined by interaction between the politeness and conventionality encoded in each strategy. It also seems that the first two types were more successfully transferred to English from Japanese.

In a previous study, Takahashi and Beebe (1987) compared the written refusals of 20 non-native speakers (NNS) of English in Japan and 20 NNS of English in the United States to the written refusals of 20 native speakers (NS) of Japanese and 20 NS of English. They found that although pragmatic transfer from Japanese to English occurred with both ESL and EFL 
groups, it happened more with the EFL group. Their results also showed that although transfer occurred among both lower and higher proficiency learners, the researchers claimed that the latter were more likely to transfer L1 sociocultural norms because they had enough control over the linguistic forms of the second language to express how they felt.

The two studies mentioned above serve as examples of when pragmatics instruction could be beneficial, and it also demonstrates that the teaching methodologies should be catered to the audience. As with other aspects of language learning, not all learners will have the same needs, and they may or may not transfer successfully from their L1.

In order to provide a more complete description of the issues involved in the teaching of L2 pragmatics, the next subsections will first examine the role of environment in the development of pragmatic ability and then explore the different types of instruction that are most commonly used.

\subsubsection{The Role of the Environment in Pragmatic Instruction}

The role of learning environment in the development of a second language has been extensively researched in the field of second language acquisition (SLA). Numerous studies compare the effects of learning several aspects of a L2, such as the acquisition of vocabulary and the order of learning of certain grammatical structures, in an EFL setting (where English is learned in the environment of one's native language), over learning the same aspects in an ESL setting (where the learning of English happens in an environment in which this language is spoken). The common assumption is that learners in the latter environment have more gains in terms of overall language ability because they are exposed to input and given opportunities of interaction in the L2 both inside the classroom (through formal instruction) and outside (through 
contact with the target language community). EFL learners, on the other hand, are mainly exposed to the target language within the context of the classroom, and thus, do not have varied opportunities for being in contact with authentic language use.

This assumption is also carried over to the development of pragmatic ability in these two different settings. Taguchi (2008, p. 424) further restates the importance of the learning environment in pragmatic development because "pragmatic competence entails the ability to control the complex interplay of language, language users, and the context of language use”. Some previous studies have in fact demonstrated the superiority of ESL learners in contrast to EFL learners for pragmatic development (Bardovi-Harlig \& Dörnyei, 1998; Li, 2000; Matsumura, 2001, 2003; Olshtain \& Blum-Kulka, 1985; Takahashi \& Beebe, 1987).

Bardovi-Harlig and Dörnyei (1998), for example, investigated three factors that may contribute to a learner's awareness of errors in grammar and in pragmatics, namely the environment (ESL or EFL), the level of proficiency, and the awareness of the learners' instructors. Two samples were collected for this study: the primary sample, which consisted of 543 learners and 53 teachers in the U.S. and in Hungary, and the secondary sample, 112 Italian primary school teachers attending an EFL course. The instrument used was a video that presented a contextualized pragmatic and grammatical judgment task, including 22 scenarios elaborated to elicit one of the following speech acts: requests, apologies, suggestions, and refusals. The results demonstrated that ESL learners (and teachers) were more aware of pragmatic violations than grammatical errors, whereas EFL learners (and teachers) were more sensitive to grammatical errors.

Recent studies, however, have shown that the ESL setting is not always more beneficial, because learners do not always use the L2 more or make more progress than their peers who 
study the language in an EFL environment (e.g., Dewey, 2004; Tanaka, 2004). Since most studies that specifically examined the development of pragmatic ability have focused on EFL learners and on the effects of instruction in this type of setting based on the assumption that they are not as exposed to authentic language use, further empirical investigation of learners in an ESL environment is certainly needed.

\subsubsection{Types of Instruction Methods}

Different types of instruction methods have been developed based on classroom research on interlanguage pragmatics. Specifically, two types of research studies have informed the development of classroom techniques aimed at improving learners’ pragmatic fluency: Observational and interventional studies. Kasper (2001) reviewed data-based research on pragmatic learning in the second or foreign language classroom and found out that early observational studies focused more on language use rather than on development of pragmatic ability, and since the first study (Long et al., 1976) the focus of the observation was mainly on speech acts, discourse functions, discourse markers and strategies, discourse organization and management, politeness and repair. These studies also compared different forms of classroom organization (teacher-fronted versus student-centered) and different forms of activities (roleplays versus pair work, for example), mainly looking at which ones offered more opportunities for pragmatic input and conversational practice. Between 1992 and 1999, the observational goal was expanded to the sociocultural context in which language use was taken place, informed in particular by language socialization theory and sociocognitive theory. Out of the eighteen observational studies she reviewed (ranging from 1976 to 1999), only two were in an ESL setting (Poole, 1992, and Ellis, 1992). 
Kasper also reviewed seventeen interventional studies (dating from 1981 to 1998). The teaching goal of these studies included discourse markers and strategies, pragmatic routines and strategies, pragmatic fluency, sociopragmatics, sociostylistic variation, implicatures, and speech acts (compliments, apologies, complaints, refusals, requests, thanks, commands). Most of the studies compared two different approaches to teaching pragmatics (e.g., explicit versus implicit, rule explanation versus consciousness raising, focus on form versus focus on formS, metapragmatic discussion versus additional input, input enhancement versus explicit, eclectic versus suggestopedia) and a few looked at teachability of pragmatics. The assessment instruments preferred were role-plays, discourse completion tasks, and multiple-choice (in that order). Only seven studies were conducted in an ESL setting (Billmyer, 1990a, 1990b; Bouton, 1994a; Morrow, 1996; Fukuya, 1998; Fukuya et al., 1998, Fukuya \& Clark, in press), and the samples of all of these seven consisted of intermediate to advanced learners.

In order to provide the rationale behind the instructional methods selected for this current study, some studies will be discussed to account for the different types of pragmatics instruction available. These studies differ, however, in terms of what type of instruction is most beneficial (inductive, deductive, implicit, and/or explicit) and whether the target language is being learned in an ESL or in an EFL setting. In some cases instruction might not even bring any significant advantages.

An exploratory study by House (1996) sought to investigate which type of instruction (implicit, through input and practice, or explicit in the functions and use of conversational routines) was more beneficial for advanced adult EFL language learners. The hypothesis is that explicit instruction in the use of routines leads to improved pragmatic fluency. The sample consisted of two randomly selected groups of advanced EFL students in Germany. Both groups 
were taught in a communicative course, but one with implicit instruction and the other with explicit instruction. Data collection involved informal interviews, audio recording of learnerlearner and learner-native speaker interactions, and three pragmatic tests consisting of role-play productions. The results showed that while both groups improved their pragmatic fluency, the one that received explicit instruction performed better, suggesting that combining explicit awareness-raising techniques with appropriate situations for learners to practice is essential when teaching L2 pragmatics.

Martínez-Flor and Soler (2007) also confirmed the positive effects of instruction, but from a different perspective. Their study focused on the role of instruction in developing learners’ pragmatic awareness of the speech act of suggestions. The researchers aimed first to investigate whether pragmatic awareness was improved after instruction, and secondly, which type of instruction (i.e., implicit or explicit) was more effective. The participants, 81 EFL learners in Spain with an intermediate level of English, were distributed in three groups: group A $(n=24)$ received explicit instruction, i.e., they received explicit metapragmatic explanations on suggestions and were given awareness-raising activities and also activities offering opportunities for production; group B $(n=25)$ received implicit treatment and was the use of suggestions by means of input enhancement and recast techniques; group C $(n=32)$, the control group, didn’t receive any instruction on this speech act. The researchers administered a pre-test and a post-test, the latter consisting of eight different situations and asked students to assess their appropriateness using a 5-point rating scale. Differing from House, their findings prove the "benefits of both explicit and more implicit instructional approaches to developing learners' pragmatic awareness in the EFL classroom” (p. 47). 
In a study by Takimoto (2008), the effectiveness of the deductive and inductive approaches (including inductive instruction with problem-solving tasks and inductive instruction with structured input tasks) in improving EFL learners’ pragmatic competence were examined. The participants, 60 native speakers of Japanese, were divided in four groups (each group received one type of instruction mentioned above and one group didn’t receive any treatment) and all of them completed a pre-test, a post-test, and a follow-up test. The findings confirm that some instruction is better than none, and that inductive instruction combined with problemsolving tasks or structured input tasks can be considered more effective. This study also discusses and emphasizes the use of meaningful tasks during inductive instruction that "lead learners to process both pragmalinguistic and sociopragmatic resources at the greatest possible depth” (p. 381).

A great number of research studies demonstrated that pragmatic development, though observed to occur without formal intervention, can be facilitated by instruction, "particularly when that instruction is of an explicit nature” (Rose \& Kasper, 2001, p. 121). Thus, the instructional treatment of this current study intentionally included different methodologies and techniques, but focused on explicit teaching of pragmatics aspects of language use by means of a deductive approach. More information regarding the instructional treatment will be provided in the next chapter.

\subsection{Pragmatic Assessment}

Even though researchers and educators have focused on developing methods of teaching learners to use language in a communicative way - basically since the early 1970's when there was a shift from focusing on language forms alone to a focus on language use - not many 
methods of assessing learners’ ability to communicate have been developed and extensively tested in empirical research, especially when it comes to assessing what it is that learners are able to do in a pragmatically appropriate way.

One important issue of measuring pragmatic competence is intrinsically related to the nature of pragmatic ability itself, which involves authentic language use. Some researchers prefer to analyze natural occurring data, by observing the production of particular speech acts in realworld interactions, or by using corpus data. In general, researchers tend to focus their collection and analysis of data on one or two speech acts at a time. Boxer (1993), for instance, analyzed indirect complaints in conversational interactions between Japanese learners of English as an L2 and their English speaking peers. Bardovi-Harling and Hartford (1993) analyzed suggestions and rejections performed by advanced nonnative speakers of English and their native speaker peers in academic advising sessions. Jiang (2006) also looked at the speech act of suggestions in an academic setting, by analyzing professor-student interaction during office hours and studentstudent study groups. Rose (2001) took a different perspective and examined a corpus of compliment and compliment responses in forty American films and later compared their realization to naturally-occurring data from the speech act literature.

Nonetheless, as Vellenga (2008) points out, analyses such as the ones mentioned above, are highly impractical mainly due to the way these interactions are set up and to the fact that some speech acts are not as frequent as others. Other techniques of data collection have been developed to facilitate the measurement of pragmatic ability. Brown (2001) cites six types of instruments: the oral discourse completion tasks (ODCTs), discourse role-play task (DRPT), discourse self-assessment tasks (DSAT), role-play self-assessments (RPSA), written discourse completion tasks (WDCTs), and multiple-choice discourse completion tasks (MDCTs). The first 
four types will be briefly described here, and the last two will be discussed in further details because they were selected for this study (see Yoshitake, 1997 and Yamashita, 1996a, 1996b for a complete review of the six measurement types).

The first four types of instruments are specifically designed to measure the appropriateness of students' oral production, and for that purpose, their responses are often recorded on a tape or video. An oral discourse completion task consists of a recording of a situation which students are required to listen to and to say aloud what they would say in that specific situation. In a discourse role-play task the students are given the description of a situation and required to play a particular role with another person in that situation. When performing a discourse self-assessment task, students are required to rate their own ability to perform the pragmatics necessary in a given situation, which had been previously described to them. A role-play self-assessment task combines the last two instruments: First, the learners participate in a role-play (which is recorded on a video recorder) and then are asked to judge their own pragmatics performance.

The last two types of instruments, WDCTs and MDCTs, consist of situations that require students to either write or select what they would say in a situation, but not via oral tasks. These two instruments involve both comprehension and production of pragmatic aspects of language use. A written discourse completion task requires students to read the description of a scenario (which includes setting, participant roles and genders, status differentials) and the beginning of a dialogue. Students are then asked to write what they would say in each situation. As in the WDCTs, a multiple-choice discourse completion task provides students with a description of a scenario and sometimes the beginning of a dialogue, but it requires students to select the best 
option of what should be said instead of asking them to write it. For obvious reasons, the latter is easier to score than the former.

Although DCTs (both multiple-choice and written) have been largely used in pragmatics research to compare the production of speech acts by non-native speakers of different languages to native speakers of a target language and to measure learners’ pragmatic competence and development, they have also been criticized. For instance, Brown (2001), who compared the six types of measures in two different settings: an English as a foreign language setting and a Japanese as a foreign language setting, argues that even though both MDCTs and WDCTs are easier to administer, they don't encourage self-reflection. He also states that these two types of tasks "require the students only to produce and understand written language and therefore do not encourage oral production” (p. 319), i.e., not only learners’ reading and writing skills may affect their overall performance, but also their performance might not be an exact reflection of how they would sound if they actually uttered the sentences. Other sources of criticism come from the fact that "situations may be culturally inappropriate or implausible for certain groups of learners" (Vellenga, 2008, p. 47) and that it is also difficult to construct prompts that are at the same time easy to be read and that provide all the contextual information necessary to describe a specific situation (Roever, 2004).

While it would be beneficial and more thorough to use multiple approaches to data collection using different types of instruments, due to the large sample of participants and to time constraints, the ones selected for this study were the WDCTs and MDCTs because of the practicality of administration. Thus, care was taken in this current research study to develop items that consisted of scenarios that reflected situations which the participants were likely to encounter in the target language community, such as interactions with classmates, teachers, 
friends, neighbors, relatives, and service-related people (e.g., a sales representative, a police officer, among others). Even though the scenarios involved male and female participants and people from different statuses, in order to keep it as realistic as possible, the students were always required to respond to the situation as if they were actually part of it (that is to say, all responses were related to what “you would say in this case”). Moreover, in order to account for the conversational aspect of the assessment, the graders were instructed to read students' responses aloud to facilitate their listening judgment and not to take points off if a word was misspelled (as long as it didn’t hinder comprehension) when the written discourse completion tasks were scored.

\subsection{The Present Study}

The literature in the field of second language acquisition and in related areas, in addition to the questions suggested for future research, indicate specific gaps in the body of research in pragmatics. First, guided by the claim that EFL students lack sufficient exposure to authentic language use, many studies have focused on the development of pragmatic ability in this type of environment (e.g., Jeon \& Kaya, 2006). There is a clear need to better understand ESL learners’ acquisition of L2 pragmatics and to examine the effects of instructional pragmatics in terms of both comprehension and production of a variety of speech acts by learners in an ESL setting.

Second, most research has investigated the pragmatic proficiency of high-intermediate or advanced learners, usually at the university level (e.g., Bardovi-Harlig \& Hartford, 1993; Bardovi-Harligy \& Dörnyei, 1998; House, 1996). More evidence - for and against - is needed to explore the interdependence of grammatical and pragmatic ability, especially with lower level learners (Bardovi-Harlig, 1999). 
A third gap can also be found in terms of research design. Kasper (2001), for instance, notes that very few interventional studies include a delayed post-test - most of them consist of varieties of pretest-posttest (see Lyster, 1994; Kubota, 1995; Morrow, 1996; Pearson, 1998, for exceptions). She also points out that most studies do not include a control group to allow for comparison of post-treatment effects. These interventional studies often compare groups who received different teaching approaches (direct versus indirect, for example), rather than groups who either received or not received pragmatics instruction.

The present study aims to contribute to the body of research in pragmatics by attempting to fill the gaps mentioned above. Its goal is to investigate ESL learners' knowledge of pragmatics and how instruction might help them develop this knowledge. The participants, learners from a variety of native language backgrounds and different levels of proficiency in English, are divided into two groups (experimental and comparison) so that the results of the instructional treatment can be assessed in terms of whether the experimental group improved or not. Specifically, this study aims to address the following research questions:

1. Up to which extent are these learners aware of pragmatic knowledge?

2. What is the relationship between language proficiency and pragmatic competence?

3. What are the effects of pragmatics instruction in this setting? 


\section{Methodology}

This research study attempted to investigate ESL learners’ knowledge of pragmatics and to show how instruction might help them develop this knowledge. This chapter outlines the specific details of the study including a thorough description of the participants, the development processes for the instructional materials, the language proficiency test and the pragmatics assessment instruments, scoring procedures, data collection procedures, and data analysis.

\subsection{Participants}

The participants in this research $(\mathrm{n}=39)$ consisted of thirty-eight adult learners of English as a second language in the Intensive English Program (IEP) at West Virginia University and one student enrolled in a university-level English course at this institution. Because of the nature of the current study, which required students' participation over a period of 4 weeks, some students who initially volunteered to take part in this project were not included in the final analysis. To be considered a student participant, they had to fill out a demographic questionnaire, take a language proficiency test, complete the pre-, post-, and delayed post-test, and attend all four instructional sessions. Attrition from the original enrollment $(n=71)$ was approximately 45\%. Out of the final 39 participants, 21 were in the experimental group and 18 were in the comparison group.

Considering that the male/female population enrolled in the IEP in the spring semester of 2012 was approximately $80 \%$ / 20\%, of the participants included for analysis in this study, there were 31 male participants but only 8 female participants. Their ages ranged from 18 to 34 years with an average of 23.79 years. Since the great majority of the IEP students are studying English 
prior to entering an academic course of study, 25 participants had a high school diploma as their highest degree received, 12 had a bachelor's degree and only 2 had a master's degree.

The participants involved in this study were predominantly from Arabic L1 backgrounds $(n=29)$, but included speakers of Spanish $(n=3)$, Japanese $(n=4)$, Chinese $(n=1)$, Korean $(n=1)$, and French $(n=1)$. The distribution of the native language backgrounds of the student participants in each group are shown in Table 3.1.

Table 3.1

Native Language Background of Participants

\begin{tabular}{lllllll}
\hline GROUPS & Arabic & Japanese & Spanish & Chinese & Korean & French \\
\hline A (Experimental) & 19 & 0 & 1 & 1 & 0 & 0 \\
B (Comparison) & 10 & 4 & 2 & 0 & 1 & 1 \\
\hline
\end{tabular}

Out of the 39 participants, only 3 reported in the questionnaire that they spoke a third language (besides their L1 and English), and other 2 students said they have studied a third or a fourth language, but didn't speak it. The participants were also asked to report their experience living in a foreign country prior to coming to the United States. Table 3.2 shows the students' foreign language (other than their L1 and English) and overseas experience (other than the United States). 
Table 3.2

Foreign Language and Overseas Experience of All Participants

\begin{tabular}{llll}
\hline GROUPS & $\begin{array}{l}\text { Speak } \\
\text { another } \\
\text { language }\end{array}$ & $\begin{array}{l}\text { Study } \\
\text { another } \\
\text { language }\end{array}$ & $\begin{array}{l}\text { Lived in a } \\
\text { foreign } \\
\text { country }\end{array}$ \\
\hline A (Experimental) & 0 & 1 & 5 \\
B (Comparison) & 3 & 2 & 3 \\
\hline
\end{tabular}

The participants had different previous English learning experience and most of them (approximately 38\%) reported more than three years of previous English study. Table 3.3 shows the distribution of length of students’ previous English study.

Table 3.3

Length of Previous English Study of All Participants

\begin{tabular}{lllllll}
\hline GROUPS & $1-6$ & $6-12$ & $1-2$ & $2-3$ & Over 3 & Total N \\
& months & months & years & years & years & \\
\hline A (Experimental) & 6 & 4 & 2 & 1 & 8 & 21 \\
B (Comparison) & 3 & 3 & 4 & 1 & 7 & 18 \\
\hline
\end{tabular}

The students also reported how long they have been studying in an IEP setting in the United States and how long they have been living in this country, as shown in Table 3.4. The majority of them (about 48\%) had only been studying in an IEP setting for less than 4 months at the time of this study. The ESL student did not study in an IEP in the United States and no student in this study has been living here for more than 2 years. 
Table 3.4

Length of Stay in the United States and Length of Study in an IEP Setting

\begin{tabular}{l|lll|lll}
\hline GROUPS & \multicolumn{3}{|l|}{ Length of stay } & \multicolumn{2}{l}{ Length of study in an IEP } \\
& setting & \\
\hline & $1-4$ & $5-12$ & Over 1 & $1-4$ & $5-12$ & Over \\
& months & months & year & months & months & 1 year \\
A (Experimental) & 9 & 9 & 3 & 10 & 9 & 2 \\
B (Comparison) & 6 & 9 & 3 & 9 & 5 & 3 \\
\hline
\end{tabular}

In order to have some perspective of the students’ interaction with native speakers and the impacts of being in an ESL setting, the participants were asked how often they interact with native speakers of English after class. Almost half of the participants (approximately 48\%) reported that their interaction is less than one hour a day, as shown in Table 3.5. Two students did not answer this question.

Table 3.5

Students’ Interaction with Native Speakers of English after Class

\begin{tabular}{lllllll}
\hline GROUPS & $\begin{array}{l}\text { Less } \\
\text { than 1 } \\
\text { hour a } \\
\text { day }\end{array}$ & $\begin{array}{l}1-2 \\
\text { hours a } \\
\text { day }\end{array}$ & $\begin{array}{l}2-3 \\
\text { hours a } \\
\text { day }\end{array}$ & $\begin{array}{l}\text { More } \\
\text { than 3 } \\
\text { hours a } \\
\text { day }\end{array}$ & $\begin{array}{l}\text { Missing } \\
\text { answers }\end{array}$ & Total N \\
\hline A (Experimental) & 7 & 8 & 3 & 1 & 2 & 21 \\
B (Comparison) & 12 & 4 & 2 & 0 & 0 & 18 \\
\hline
\end{tabular}

The participants’ overall proficiency in English also varied and their proficiency level was measured by an independent language proficiency test designed specifically for this study (which will be described further in details). This proficiency test had 54 questions and the scores 
ranged from $16 \%$ to $87 \%$. Even though the students were currently placed in different levels in the IEP program or in an ESL class, their grades on the proficiency test for the most part did not match their IEP levels. For the purpose of dividing the students in the comparison and experimental groups of this research, only their proficiency test score was considered. Originally, each group contained the same number of beginner, intermediate, and advanced students. Table 3.6 shows students' scores on the language proficiency test.

Table 3.6

Proficiency Test Scores

\begin{tabular}{lllllll}
\hline Students & $90-100 \%$ & $80-89 \%$ & $70-79 \%$ & $60-69 \%$ & $\begin{array}{l}\text { Below } \\
59 \%\end{array}$ & Total N \\
\hline A (Experimental) & 0 & 0 & 1 & 2 & 18 & 21 \\
B (Comparison) & 0 & 1 & 2 & 0 & 15 & 18 \\
\hline
\end{tabular}

Based on these scores, the great majority of the participants could be characterized as elementary learners of English. However, the test only measured reading and grammar skills using multiple-choice questions that were very similar to the questions on the TOEFL ${ }^{\circledR}$ (Test of English as a Foreign Language) exam, and, thus, of a higher difficulty.

In order not to affect the results of this research study, the students were only told in the beginning of the process that they would have an opportunity to learn to communicate more effectively in English and that information obtained from this study could be beneficial in understanding the communicative skills and intercultural competence of ESL learners. 


\subsection{Instructional Treatment}

\subsubsection{Experimental Group (Group A)}

The treatment delivered over four sessions of one hour each to the Experimental Group aimed at developing students' language proficiency, mainly their communication skills, through explicit and formal instruction of English pragmatics. The content of the lesson plans was set up in such a way that students moved toward more complex tasks in a logical manner. Thus, the first lesson consisted of activities that focused mostly on raising students' awareness of pragmatic differences across languages, and students were involved in discussions in which they had to explain why, when, how, and where certain linguistic structures were preferred over others. The following lessons focused not only on recognizing pragmatic infelicities and comprehending implied meanings, but also on producing socially appropriate language. Although the focus was mostly on speech acts, the lesson plans included activities about conversational management, conversational openings and closings, and sociolinguistic aspects of language use as well. (See Appendix A for complete lesson plans and handouts.)

Following Vellenga’s (2008) lesson design, all four lessons consisted of activities that included explicit metapragmatic discussion (but with relatively simplified vocabulary), practice with identification of status relationships, gender and age of the speakers, the speaker's goal, and where the interaction was taking place. Metapragmatic discourse rating tasks, in which students identified the speaker, target, impact, and goal of a particular speech act, and contrastive analysis discussion, in which they compared their native language (and/or other languages they knew) to English, were mostly done in the beginning of a session. Role-play production tasks were also present in every lesson, usually in the second-half of the session, so that students had plenty of 
opportunities to practice their sociopragmatic and pragmalinguistic skills, and later discuss their performance.

As mentioned before, the main goals of the first lesson were to introduce the topic of how pragmatics plays a key role in successful communication and to raise learners’ awareness of pragmatic differences across languages, by increasing their awareness and sensitivity to cultural differences and providing opportunities for students to express their views. To get students involved and to facilitate the introduction of what pragmatics is about, the first activity was not randomly selected; it particularly focused on a very common pragmatic mistake made by our IEP students: Addressing the teacher. Students were required to read situations that described a critical incident, i.e., a situation in which there is miscommunication between people from two different cultures, and come up with their own solutions to the problem presented. Both situations were taken from the book "Cultural Awareness” (Tomalin \& Stempleski, 1993) and the first one described the interaction between a new student, Liliana, and her teacher, a nativespeaker of English. She called him “Teacher”, and the teacher’s response was a request for her not to address him as “Teacher”, but rather “Alan” or “Mr. Jones”. The second situation described the interaction between an Asian student and her teacher. The teacher paid her a compliment concerning her English skills and the student did not respond appropriately. After working on their own, students were invited to discuss if the situations described were surprising in any way, how they would react had the interactions happened in their native languages, and also suggest ways to address a teacher, bearing in mind contextual features such as status relationships, level of formality, and the content of the message. The second activity was a brief oral brainstorming section with the students about what kinds of things influence the choices of certain linguistic structures over others (what we say to whom, how we say, why, and when). In 
the third activity, students had to compare some examples and indicate who would say each one, when, and where, based on the discussion in activity 2. In the last activity, students were asked to compare requests and refusals (in different situations) based on the level of difficulty (as perceived by the students). For example, “compared with 'asking a friend for a pen', how easy/difficult is 'asking your teacher to reschedule the exam because you need to attend your good friend's wedding?” (Adapted from Taguchi, 2003). Their homework assignment was to informally observe the language use going on in their classes, in their teachers' offices, around campus, or on TV. They should note, for example, how people greet each other, how they take leave of each other, how they ask for things, etc., keeping in mind the contextual features discussed in today's lesson.

The remaining three instructional sections followed the same format: presentation of one or more speech acts (input - authentic language samples used as examples), discussion and analysis of the linguistic forms, and role-plays. Students were always asked how they could say something, and, in most cases, they (as a class) came up with a good variety of linguistic forms to accomplish a particular function. When that was not the case, the teacher provided other options, always drawing students' attention to the level of formality, the degree of imposition, and other aspects, such as gender, age, and relationship between the speakers.

The second lesson plan focused on requests, the third on apologies, and the fourth on compliments and suggestions. Responses to these speech acts were also discussed, including both acceptance and refusal. The goals of these lessons consisted of helping learners become familiar with a range of pragmatic devices and providing them with opportunities to practice. All examples and activities involved situations that the students were likely to encounter in the target language community, such as interactions with their teachers, advisors, classmates, friends, 
neighbors, strangers, and co-workers. Example (1) shows a brief and controlled role-play activity students performed in lesson 2 (adapted from Kehe \& Kehe, 2009). Example (2) illustrates an item that students completed during the third lesson (adapted from Wall, 1998).

\section{(1) Directions: Student A / Student B}

\begin{tabular}{|l|l|}
\hline $\begin{array}{l}\text { Student A: Say your sentences to Student B. } \\
\text { Then listen to Student B. }\end{array}$ & $\begin{array}{l}\text { Student B: First listen to student A. } \\
\text { Then make your request. }\end{array}$ \\
\hline $\begin{array}{l}\text { 1. Tell your partner, “I'm a police officer.” } \\
\text { Listen to your partner's request. Then } \\
\text { refuse to help. Give an excuse. }\end{array}$ & $\begin{array}{l}\text { 1. Ask your partner to tell you where } \\
\text { the nearest bus stop is. }\end{array}$ \\
\hline $\begin{array}{l}\text { 2. Say, “I'm your boss.” Listen and refuse. } \\
\text { Give an excuse. }\end{array}$ & $\begin{array}{l}\text { 2. Ask your partner to give you 3 days } \\
\text { off from work. (You are tired and you } \\
\text { need a rest.) }\end{array}$ \\
\hline 3. Say, "I'm your friend.” Listen and agree. & $\begin{array}{l}\text { 3. Ask your partner to lend you his/her } \\
\text { cellphone. You need to call your } \\
\text { mother. }\end{array}$ \\
\hline
\end{tabular}

(2) Directions: Here are some situations where an apology is necessary. Use a different beginning for each one you make. Add other parts of the apology if they are appropriate. When you finish, sit with a partner and practice responding to each of the 4 apologies each one of you gave.

a. You dropped and broke your friend's hairdryer.

You:

b. You borrowed and then forgot to return a classmate's dictionary. You:

c. You backed your car into your neighbor's fence and broke the gate. You:

d. You're 15 minutes late picking up a friend because you got a phone call as you were going out the door.

You:

While most of the activities required the students to either analyze, say or write what one should say in a specific situation, one particular activity in the third lesson plan required students to judge the appropriateness of requests made by students in an e-mail in which they asked their professor to give feedback on a piece of written work. This activity was selected because such an 
interaction is very common in their daily school routine and it is often problematic. Example (3) is an excerpt of this activity (adapted from Weasenforth \& Biesenbach-Lucas, 2000).

(3) Directions: You are submitting a piece of written work by e-mail to your academic professor for him/her to read and you want to ask him/her to provide feedback. Which of the requests below would you use in your e-mail? Which ones are appropriate? Which ones are inappropriate? Why do you think so?

\begin{tabular}{|l|l|l|l|l|}
\hline \multicolumn{1}{|c|}{ Request } & Appropriate & Inappropriate & Not Sure & Reason \\
\hline Your thoughts on this? & & & & \\
\hline $\begin{array}{l}\text { I'm looking forward to any } \\
\text { feedback you can provide. }\end{array}$ & & & & \\
\hline I need your advice. & & & & \\
\hline $\begin{array}{l}\text { Please notify me, hopefully before } \\
\text { the weekend is over, on what I } \\
\text { should do. }\end{array}$ & & & & \\
\hline $\begin{array}{l}\text { I sent my research paper for you to } \\
\text { put your comments on last Friday. } \\
\begin{array}{l}\text { Up to today, I do not receive any } \\
\text { from you. }\end{array}\end{array}$ & & & & \\
\hline
\end{tabular}

\subsubsection{Comparison Group (Group B)}

The comparison group, which was taught lessons on other topics without intervention, also had to attend four sessions of one hour each. Since all participants were told that this project would help them communicate more effectively, the content of the lesson plans to the comparison group was also designed to give students more speaking practice without, however, touching on pragmatics aspects of language use (See Appendix B for a sample lesson plan.) 
Students in this group participated in conversations about familiar topics (such as predictions for the future) and practiced asking for more details. They also produced short oral descriptions and practiced the technique of describing words, which is a useful technique when one doesn't know how to say a specific word in the target language. Problem areas in pronunciation (such as the pronunciation of specific sounds, 'l', 'r', 'v', 'p', 'b', and intonation of questions) were also addressed during the lessons. Some grammatical forms were covered, particularly the use of present perfect to initiate a conversation, indirect questions, and reported speech.

\subsection{Instruments}

The instruments used in this research study consisted of a student demographic questionnaire, a language proficiency test, and three versions of a pragmatics test, which were counterbalanced for use as pre-test, post-test, and delayed post-test. All participants were asked to fill out the demographic questionnaire (see Appendix C), which included questions about students' native language backgrounds, experience living in a foreign country prior to coming to the United States, length of previous English study, interaction with native speakers of English after class, and length of stay in the United States and length of study in an IEP setting. The next subsections will provide a detailed description of the language proficiency test and of the pragmatics tests.

\subsubsection{Language Proficiency Test}

The participants' overall proficiency in English was measured by an independent language proficiency test designed specifically for this study (see Appendices D for the test and E for the answer key). Although this test was based on the format of the paper version of the 
TOEFL $^{\circledR}$ (Test of English as a Foreign Language), it did not attempt to measure students’ listening skills. The language proficiency test used in this study was developed to measure students’ ability to recognize grammatically correct English and to understand written English. Students were allowed 50 minutes to complete the entire test, which was divided into 3 parts (Structure, Written Expression, and Reading Comprehension), and contained a total of 54 multiple-choice questions, primarily selected from the textbook "Longman Preparation Course for the TOEFL TEST: The Paper Test”. Students had approximately the same amount of time to answer each question as they would have if they were taking the actual TOEFL test. In addition, the same proportion of easy, moderate, and difficult questions was kept as in the original version. The reliability coefficient for the language proficiency test, using K-R21 to calculate the reliability estimate, was 0.75 .

All items on this test were hand scored by the researcher based on the answer key provided by the book. Missing answers were counted as incorrect and all the items were scored as right or wrong. Test takers received 1 point for each correct answer, and 0 points for an incorrect answer. The total maximum score for the test is 54 and the percentage score was used in my later analysis.

This language proficiency test was elaborated based on the paper version of the TOEFL because this test is administered twice a semester by the WVU Intensive English Program and, therefore, the great majority of students are familiar with its structure. It was not possible to use students' scores on the actual TOEFL test to measure their proficiency level for this specific research study due to two main reasons: First, IEP students are not required to take the TOEFL test every semester (and thus it would be deceptive to use their previous scores if they had one); and second, since the test is only administered in the middle and at the end of each term, there 
would not be enough time left to conduct this research had all the participants taken it at midsemester.

\subsubsection{Pragmatics Tests}

The pragmatics tests were designed to assess learners’ recognition of pragmatic infelicities, and comprehension and production of five speech acts, namely requests, refusals, apologies, compliments, and suggestions. Pragmatic competence was measured quantitatively, through discourse judgment tasks, multiple-choice discourse completion tasks (MDCT) and written discourse completion tasks (WDCT). Three forms of the pragmatics test were developed specifically for this study and they were counterbalanced for use as pre-test, post-test, and delayed post-test (Appendix F shows the Table of Specifications for each version of the pragmatics test and Appendices $\mathrm{G}$ and $\mathrm{H}$ include all the tests and their answer key).

All the versions were divided into 3 parts, each one consisting of one type of task, and contained a total of 20 questions. Items were developed based on previous research on pragmatic assessment of speech acts and the situations were taken from several research studies (BardoviHarlig \& Griffin, 2005; Martínez-Flor \& Soler, 2007; Taguchi, 2003; Vellenga, 2008). The items were modified from the original versions and/or created to maintain consistency across the three versions by presenting the same level of vocabulary and grammatical difficulty and consisting of student-oriented situations and situations that were likely to be encountered outside school by the participants of this research study. Three native speakers of English helped develop/modify the items and write the answer key. The items also varied according to degree of familiarity between interlocutors, differences in social status, and degree of imposition. Thus, the situations involved conversations between classmates, students and advisors/professors, neighbors, family members and also dialogues likely to happen in a workplace and in service encounters (such as 
interviewing for a job, talking to a co-worker, or ordering a snack at a coffee shop). Some items also required that students understood conventional and non-conventional implicatures.

In the first section of each test, students were asked to imagine that all six situations, which involved conversations between classmates (two males and one female) and between them and their teachers, took place in the United States. The participants' task was to read the conversations and decide if one of the character's responses was appropriate or not by marking YES or NO. Even though explanations as to why a particular response should or shouldn't be considered appropriate would reveal a much more detailed insight on the participants' pragmatic awareness, the items did not require any written clarification due to the impracticality of scoring such a format. Example 1, from the version one of the pragmatics test, illustrates a discourse judgment task that was included in the first section of the test.

Example (1):

Situation 1: Peter and George are classmates. George invites Peter to his house, but Peter cannot come.

George: Peter, would you like to come over to my house tonight?

Peter: I'm sorry, I just can't. I'm very tired. I couldn't sleep last night.

1. Was Peter's response appropriate? $\square$ Yes $\square$ No

The second section consisted of seven multiple-choice discourse completion tasks that required students to choose the most appropriate response based on the description of a particular situation. Three choices were given for each item (the correct answer and two distractors). In all situations the students were placed in the role of the speaker, so that they could react to them in a more realistic way ("You are a student working on a project", or "You just moved in a new 
neighborhood"). Gender of the interlocutors is made explicit in only some situations. The following example was taken from the second version of the pragmatics test and illustrates a situation in which the students had to choose the option with the most appropriate request.

Example (2):

7. Situation: You are a student working on a group project. You have a big project due in three days, but you haven't started on your part of the project. You don't understand exactly what you're supposed to do, and you want to ask another member of your group for help. You know this person is a very good student who is always prepared and finishes his assignments long before they are due. What do you say in order to get this student to help you?

a. Bob, I'm sure you're already done with the assignment, but I had a few questions about my section. Do you have time to meet later today?

b. I need your help with our project. We won’t do well unless you help me.

c. Can you help me later today?

The third section consisted of written discourse completion tasks and, as in the second section, students were placed in the role of the speaker by being asked to write down what they would say in each situation. In this part there were seven scenarios followed by a short dialogue. The students' task was to complete each conversation by writing down the last line of the dialogue. The item shown below was taken from the third version of the pragmatics test and illustrates a discourse completion task in which the student is required to write down a refusal.

\section{Example (3):}

\section{Scenario: INVITATION}

Your neighbor invites you to his house to watch a football game but you hate football.

Michael: Hey, do you want to come over and watch the football game with me and my family tonight?

You: 
Students had 40 minutes to complete each test, and the three versions of the pragmatics test were scored identically. All multiple-choice items were hand scored by the researcher and a second grader (a volunteer IEP instructor). When an item was taken as it was in the original version, the answer key was preserved. The answer key to the items that were developed and/or modified was checked by three native speakers of English (two males and one female). Missing answers were counted as incorrect. The multiple-choice items on all tests were scored as right or wrong. Test takers received 1 point for each correct answer, and 0 points for an incorrect answer. The total score for section 1 was 6 and for section 2 , the maximum was 7 .

Answers to the written discourse completion tasks were graded based on a rating scale and all the items were first graded by the researcher. All the WDCT items received partial scoring. Test takers received 0 points for an incorrect or unacceptable answer, half of a point for a partially correct answer, and 1 point for a correct answer. Spelling mistakes were not taken into consideration if they did not impede communication since the answers to the dialogues were judged considering their appropriateness in conversation. Table 3.7 shows the rating scale for the WDCT items.

Table 3.7

WDCTs Rating Scale

\begin{tabular}{ll}
\hline Points & Description \\
\hline 0 & Unacceptable answer. / Did not respond. \\
0.5 & Appropriate choice of main speech act and semantic formula. May be \\
& missing a move. Inappropriate language use may be noticeable, but do not \\
& significantly impede communication. \\
& Appropriate choice of speech act, semantic formula, content, and form. \\
& There may be a few language errors but they do not interfere with \\
& communication.
\end{tabular}


Two volunteer IEP instructors, both native speakers of English, were then given the rating scale and taught how to grade the tasks. They were instructed to consider each scenario carefully and analyze the students' responses based on their judgment of appropriateness as native speakers, taking into consideration whether or not the main speech act was performed, how polite/acceptable the response was, the length of the response, and how comprehensible the answer would be if spoken to a fluent speaker of English. The instructors independently scored the questions and the final score for each question is the grade that two graders agreed on. There was no case in which all three grades were different. The total score for this section was 7.

\subsection{Data Collection Procedures}

All data collection took place during the spring 2012 semester after approval from the Institutional Review Board at West Virginia University. IEP and ESL students were asked to volunteer for this research during weeks 2, 3, and 4 of the semester via e-mail, flyers, and personal communication. IEP staff helped advertise for this project as well and the teachers were asked to take sign-up sheets to their classrooms.

After the call for volunteers was over, the researcher contacted all of them and set up two meeting times during the fifth week of the semester. Prior to the beginning of data collection, students were informed about the tests and the instructional treatment schedule. No participants were excluded from this study at this point. In the first meeting, the research study was explained in more details to the volunteers and the informed consent document (see Appendix I) was distributed. Under the supervision of the researcher and of four instructors who volunteered to do so, the participants took the pragmatics pre-test on this same day and the reason why this test was administered first is due to time constraints. The meeting could last only a little over one hour 
and this test was shorter than the proficiency test (40 minutes versus 50 minutes). Had the proficiency test been administered first, many students would not have been able to finish it. The proficiency test was then given to students in the second meeting.

In order to control for the possible difference in proficiency, students were divided into two groups (comparison and experimental) and matched based on their performance on the language proficiency test so the groups were comparable. The original composition of the groups was very comparable with respect to gender, language background, and the scores on the proficiency test. However, due to participant attrition, not all students who originally signed up to participate in this research project were included in the analysis described here. Thus, at the end of the data collection procedure, the two groups ended up with different number of participants and were not as comparable as they would have been had all the 71 participants (original enrollment) taken all the tests and attended all four instructional sessions.

The instructional treatment, divided into four sessions of one hour each, was delivered over weeks 6, 7, and 8 of the semester. Group A, the experimental group, received explicit pragmatics instruction on Wednesday (week 6), on Monday and Wednesday (week 7), and on Monday (week 8). Group B, the comparison group, received classes on other topics without intervention on Tuesday and Thursday (weeks 6 and 7). All sessions occurred outside of regular class time in Eiesland Hall, where the IEP is located. The instruction was carried out by the researcher for both groups.

On Tuesday in week 8 all students got back together again in one group and took the pragmatics post-test and on Tuesday in week 9 they took the delayed post-test. All tests were administered on a paper-based format and students had to return the test and the answer sheet 
when they were done. Students were also allowed to leave the classroom when they finished each test.

Follow-up conversations with the participants and with some of their instructors were conducted in an informal way and will be reported in Chapter 4, Results.

\subsection{Data Analysis}

The student demographic questionnaires were first analyzed to provide a complete and detailed description of the participants and facilitate analysis of assessment instruments. After the demographic data had been sorted, participants who had missed the language proficiency test, the pre-, post- or delayed post-test, or not attended all four instructional treatment sessions were omitted from the data set.

The results from the pragmatics tests were analyzed quantitatively. The first research question, addressing the extent to which ESL learners were aware of pragmatic knowledge, was described based on students’ performance on the pragmatics pre-test. In order to examine the relationship between language proficiency and pragmatic competence, the second research question, the findings were based on the correlation between students' performance on the language proficiency test and on the pragmatics pre-test. The effects of pragmatics instruction in this setting were based on the comparison made between the experimental and control group on their performances on the post-test and delayed post-test. SPSS program was used for statistical analysis and the significance level for analysis was set at 0.05 . 


\section{Results}

This chapter presents results in relation to each research question based on quantitative measures of pragmatic competence and their relationship to overall language proficiency. In addition, some qualitative data will also be analyzed, based on informal follow-up conversations with the participants and with some of their instructors conducted after the data collection procedure was over.

\subsection{ESL Learner’s Awareness of Pragmatics}

The first research question, which addressed to which extent the ESL learners in this project were aware of pragmatic knowledge, was answered based on students’ performance on the pragmatics pre-test. Descriptive statistics of their performance (shown below in Table 4.1) indicate that there is room for improvement, since the mean score was 11.43 out of a possible score of 20 (57\%), and the learners' overall scores ranged from 3.00 to $17.00(n=39, S D=3.18)$.

Table 4.1

Students' Performance on the Pragmatics Pre-Test

\begin{tabular}{llllll}
\hline Sections & $\mathrm{N}$ & Minimum & Maximum & $\mathrm{M}$ & SD \\
\hline Discourse Judgment Task (6) & 39 & 2.00 & 5.00 & 3.38 & 1.04 \\
MDCT (7) & 39 & 1.00 & 7.00 & 4.21 & 1.36 \\
WDCT (7) & 39 & .00 & 8.00 & 3.85 & 1.93 \\
Total (20) & 39 & 3.00 & 17.00 & 11.44 & 3.18 \\
\hline
\end{tabular}




\subsection{Language Proficiency and Pragmatic Competence}

The second research question, which investigated the relationship between language proficiency and pragmatic competence, was described based on the correlation between students' performance on the language proficiency test and on the pragmatics pre-test.

Descriptive statistics of the scores on the language proficiency test and on the pre-test for all the participants were correlated using Pearson Product-Moment correlation $(r=.71, p<.001)$. There was a significant positive correlation between language proficiency and pragmatic ability. Although a correlation of .71 is considered moderate, it demonstrated that when the proficiency level increased, the pragmatic level increased as well. Table 4.2 shows the descriptive statistics of students' performance on the language proficiency test and on the pragmatics pre-test.

Table 4.2

Descriptive Statistics and Correlation between Language Proficiency Test and Pragmatics PreTest

\begin{tabular}{llllll}
\hline & $\mathrm{N}$ & $\mathrm{M}$ & $\mathrm{SD}$ & $r$ & $p$ \\
\hline Proficiency Test & 39 & 38.46 & 18.79 & \multirow{2}{*}{0.71} & \multirow{2}{*}{000} \\
Pragmatics Pre-Test & 39 & 11.44 & 3.18 & \multirow{2}{*}{0.00} \\
\hline
\end{tabular}

\subsection{Instructional Effectiveness in an ESL Setting}

The third research question, which examined the effects of pragmatics instruction in an ESL setting, was answered based on a comparison made between the experimental and comparison group on the performances on the post-test and delayed post-test. 
In order to see whether the two groups were comparable before treatment, one-way ANOVA was conducted to compare their performance on the language proficiency test and their pragmatic ability based on the pragmatics pre-test. No significant difference was found between the experimental and comparison groups for language proficiency $(\mathrm{F}=2.74, p>.05)$, or pragmatic ability $(\mathrm{F}=2.78, p>.05)$. The descriptive statistics are shown in Table 4.3.

Table 4.3

Descriptive Statistics on the Language Proficiency Test and Pragmatics Pre-Test

\begin{tabular}{llllll}
\hline & & \multicolumn{2}{l}{ Language Proficiency Test } & \multicolumn{2}{l}{ Pragmatics Pre-Test } \\
\hline & $\mathrm{N}$ & $\mathrm{M}$ & $\mathrm{SD}$ & $\mathrm{M}$ & $\mathrm{SD}$ \\
Experimental Group & 21 & 33.95 & 16.88 & 10.67 & 3.27 \\
Comparison Group & 18 & 43.72 & 19.98 & 12.33 & 2.91 \\
\hline
\end{tabular}

Although the difference on language proficiency was not statistically significant, the descriptive statistics in Table 4.3 showed that the comparison group was much better to start with in terms of language proficiency, with a mean of 43.72 compared to 33.95 in the experimental group. In the following analysis on the effect of pragmatics instruction, language proficiency will be used as a covariate to tease out potential difference in the two groups regarding their language proficiency.

Repeated measures ANCOVA (analysis of covariance) was conducted to see whether there is a significant instructional effect with groups (experimental versus comparison) and time (time 1, 2, and 3) as independent variables and participants' performance on the pre-test, posttest, and delayed post-test as dependent variables. Multivariate tests showed significant main effect for time ( $\mathrm{F}=3.96, p<.05)$ and time $\mathrm{x}$ group interaction $(\mathrm{F}=4.66, p<.05)$. Between-subjects 
tests showed a marginal significance for groups $(\mathrm{F}=3.74, p=.06)$. The descriptive statistics can be found in Table 4.4 and the interaction between time and group can be seen in Figure 1.

Table 4.4

Descriptive Statistics on the Pragmatics Tests

\begin{tabular}{lccccccc}
\hline & \multicolumn{3}{c}{ Pre-Test } & & Post-Test & \multicolumn{3}{c}{ Delayed Post-Test } \\
\hline & $\mathrm{N}$ & $\mathrm{M}$ & $\mathrm{SD}$ & $\mathrm{M}$ & $\mathrm{SD}$ & $\mathrm{M}$ & $\mathrm{SD}$ \\
Experimental Group & 21 & 10.67 & 3.27 & 13.36 & 3.41 & 14.62 & 3.33 \\
Comparison Group & 18 & 12.33 & 2.91 & 12.47 & 2.94 & 12.94 & 3.31 \\
Total & 39 & 11.44 & 3.18 & 12.95 & 3.19 & 13.85 & 3.38 \\
\hline
\end{tabular}

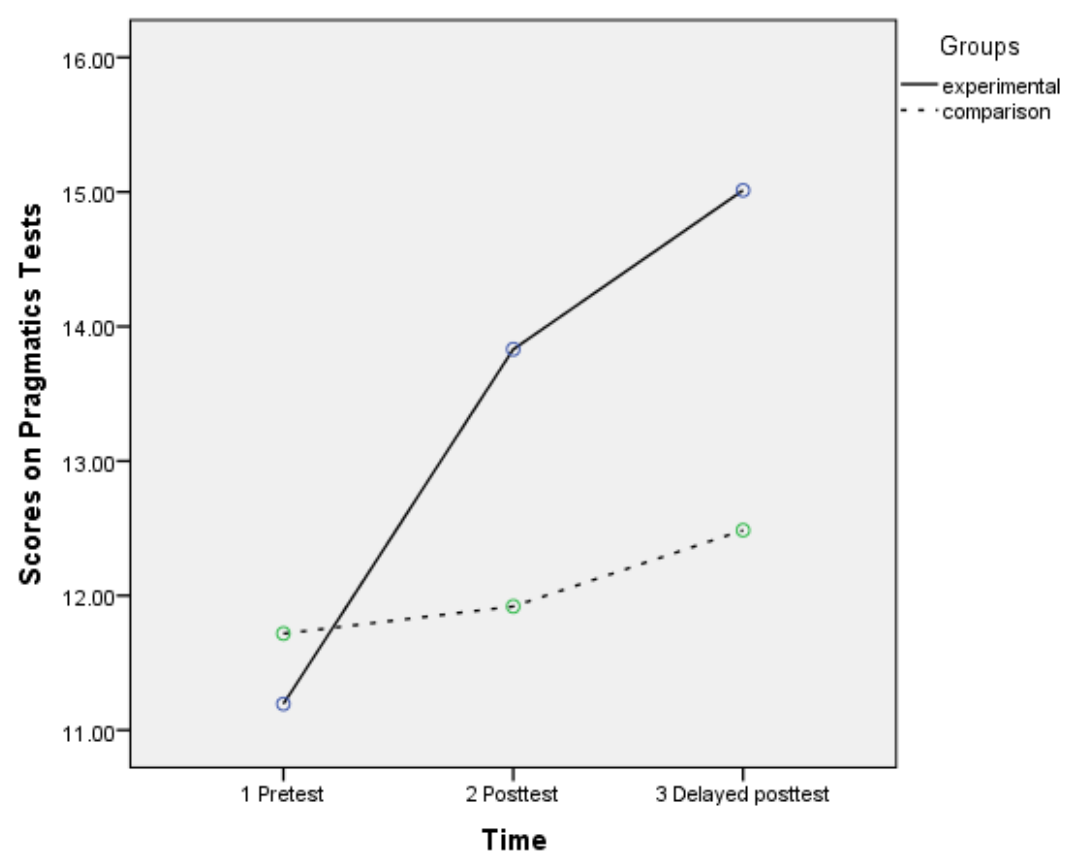

Figure 1. Time x Group Interaction. 
Further analysis based on the significant time $\mathrm{x}$ group interaction with language proficiency as a covariate showed that the two groups were not significantly different at pre-test $(\mathrm{F}=.48, p>.05)$. However, significant differences were found at post-test $(\mathrm{F}=4.90, p<.05)$ and delayed post-test $(\mathrm{F}=6.63, p<.05)$. In both cases, the experimental group performed better than the comparison group.

In order to double check the improvement within the experimental group, paired-samples T-Tests were carried out. The results demonstrated significant improvements between pre-test and immediate post-test $(t=-4.10, p=.001)$ and pre-test and delayed post-test $(t=-4.97, p<$ .001). The comparison between immediate post-test and delayed post-test also approached statistical significance $(t=-2.04, p=.055)$. The descriptive statistics and T-Test results are shown in Table 4.5.

Table 4.5

Paired-Samples T-Tests within the Experimental Group

\begin{tabular}{|c|c|c|c|c|c|c|}
\hline & & $\mathrm{N}$ & $\mathrm{M}$ & SD & $t$ & $p$ \\
\hline \multirow[t]{2}{*}{ Pair 1} & Pre-Test & 21 & 10.67 & 3.27 & \multirow{2}{*}{-4.10} & \multirow{2}{*}{.001} \\
\hline & Post-Test & 21 & 13.36 & 3.41 & & \\
\hline \multirow[t]{2}{*}{ Pair 2} & Pre-Test & 21 & 10.67 & 3.27 & \multirow{2}{*}{-4.97} & \multirow{2}{*}{.000} \\
\hline & Delayed & 21 & 14.62 & 3.33 & & \\
\hline \multirow[t]{2}{*}{ Pair 3} & Post-Test & 21 & 13.36 & 3.41 & \multirow{2}{*}{-2.04} & \multirow{2}{*}{.055} \\
\hline & Delayed & 21 & 14.62 & 3.33 & & \\
\hline
\end{tabular}

In this chapter, each of the three research questions was addressed individually. Overall, the results indicate that even in an ESL environment, learners' awareness of pragmatic knowledge was not high. Their performance on the pragmatics pre-test showed that there is room for improvement, and further analysis of the scores on the post-test and delayed post-test of the 
students in the experimental group indicated that instruction did help raise their pragmatic knowledge. Furthermore, when students' language proficiency was correlated with their pragmatic knowledge, results showed that more proficient learners tended to have higher levels of pragmatic knowledge. Even though both groups were comparable in terms of pragmatic knowledge before the beginning of the treatment, significant differences were found at post-test and at delayed post-test, with the experimental group performing better over time.

For this study, a deliberate decision was made not to analyze the information collected on the participant demographic questionnaire to support the findings of this research, and being thus so, only quantitative measures of pragmatic competence were analyzed. However, some unexpected data in the form of informal conversations with some IEP instructors and with some participants was collected after the actual data collection procedure was over. This qualitative data will be reported and analyzed here as well.

Before the call for participants started, the IEP instructors had a very basic idea about the content and the design of this research study (but advised not to disclosure any information with the students). The instructors also knew which students agreed to take part in the research study, but they did not know the groups their students were in. A few days following the administration of the delayed post-test, some instructors approached the researcher and made comments about how they had noticed improvement in some students' communicative strategies in specific conversational and written interactions. They reported changes mostly in teacher-student interaction before and after a class period, during office hours, and in informal meetings in the hallway. They also described having noticed a few changes in e-mails and notes left by some students. Most instructors commented on how students were being less direct, and providing more context when making requests, especially if these requests were high-stake, such as asking 
to turn in a late assignment or to make up an exam. Instead of saying, for example, “Teacher, can I take the exam tomorrow?”, a request such as “Teacher, I’m sorry I missed the exam, I was sick. May I have a chance to take it another time?” was uttered. Other instructors commented on the fact that students were being more polite and saying complete sentences when approaching another teacher to ask for instructions or directions. Thus, the usual “Teacher, office [instructor’s name]?” was replaced by “Excuse me, do you know where [instructor’s] office is?” to find out directions to a particular instructor's office. Nonetheless, basically all students still addressed their instructors as “Teacher,” even though proper ways of addressing people in English were discussed during the treatment sections.

Some students who were part of the experimental group also reported paying more attention to how native speakers "say and do things,” not only in real-life interactions but also on TV, in newspapers and magazines, and in social media websites. The students said they had started to compare how native and non-native speakers greet each other, how they take leave of each other, how they ask for things, and how they make, accept, and decline invitations. Besides that, they had since tried to incorporate some of the aspects they observed into their own production of language. A student of a higher level of proficiency commented that he was now checking for pragmatic mistakes when writing e-mails to his teachers, and not only grammatical ones. Another student said he had no idea that his chances of getting what he wanted automatically decreased based on the way he transmitted his message because the listener perceived it as being rude. The student in this case came to see his teacher during office hours because he wanted to tell her that he didn't have the homework assignment ready because he had gone to the bathroom when the handouts were distributed. However, he only told her "Teacher, you didn’t give me the handout so I didn’t do my homework”, and did not understand at that 
point why she got angry and replied "I am sure I distributed the handout to everyone who was in class, and I'm not going to receive any late homework assignments.” Had this student been more carefully in his choice of words (especially in the use of the pronoun "you", indicating that the teacher had done something wrong), and explained the situation better, the teacher would probably have been more inclined to help him out.

All of these follow-up conversations indicated an interesting trend: Not only were students not aware they could be sounding rude or not getting their message across appropriately, but also the instructors did not seem to perceive that, in most cases, students sounded "too direct" or "impolite" because of pragmatic failure. Teachers who were non-native speakers of English, though, seemed to have lower expectations in terms of the communicative strategies used by the students, and did not perceive some utterances as their native speaker counterparts. In the following chapter, the main findings, the limitations, and the pedagogical implications of the study will be discussed, and directions for future research will also be provided. 


\section{Discussion and Conclusion}

\subsection{Summary and Discussion of Findings}

This thesis reported on the design and administration of a study that investigated learners' knowledge of pragmatics and the effects of instruction in helping them develop this knowledge in an environment where English is taught as a second language. The study resulted in evidence to support two main arguments that have been previously discussed in SLA literature: (1) ESL learners do not just acquire pragmatics "for free” because they are constantly being exposed to authentic language use outside of the classroom, and the results of this study confirmed that there is room for improvement at all levels of language proficiency, but the relationship between language proficiency and pragmatic ability is positive and moderately strong; and (2) direct instruction in pragmatics can effectively help ESL learners develop their pragmatic competence.

Schauer (2006, p. 270) points out that "although production studies have demonstrated that a high level of grammatical proficiency does not automatically result in a corresponding level of pragmatic proficiency, the number of studies that explore the interrelationship of learners’ pragmatic and grammatical awareness has been small.” The current project addressed this gap in the body of literature by examining the relationship between language proficiency and pragmatic competence of ESL learners. The results of the study indicated a positive, but moderately strong correlation between language proficiency and pragmatic ability $(r=.71)$. Overall, the participants who scored higher on the language proficiency test also achieved higher scores on the pragmatics pre-test, demonstrating that when the proficiency level is higher, the pragmatic level is higher as well. This result supports what Bardovi-Harlig (1999, p. 677) proposed on a research agenda for acquisitional pragmatics: "Although grammatical competence may not be a sufficient condition for pragmatic development, it may be a necessary condition.” 
Example (1) illustrates how a learner of a higher proficiency level (with a score of $87 \%$ on the language proficiency test) responded to a written discourse completion task in the pragmatics pre-test that required the participant to refuse an invitation from a co-worker. In contrast, example (2) was given by a learner who scored $24 \%$ on the language proficiency test.

\section{Scenario: INVITATION}

You and Tim are co-workers. Tim invites you out to lunch but you cannot come.

Tim: Do you want to grab lunch with me?

(1) You: I'd like to, but I have an appointment. I'm sorry.

(2) You: No, I can't.

It is not the case, however, that a highly proficient student will not make pragmatic mistakes just because he/she has a high command of grammatical forms. Results from previous research in interlanguage pragmatics have shown that the pragmatics of language learners is different from native speakers', and that while advanced learners may have mastered certain areas of L2 pragmatics, their pragmatic choices can be different from native speakers' in other areas. (Bardovi-Harlig, 1996, 1999; Bardovi-Harlig \& Hartford, 1993; Blum-Kulka, 1982; Cohen, 1996). Participants’ performance on the pragmatics pre-test showed that even more proficient learners still do not exhibit targetlike norms, which "implies that instruction is warranted at all levels of development” (Bardovi-Harlig, 1999, p. 681). Example (3) is the answer written by another student who got a relatively high score on the language proficiency test, but still failed in some pragmatic aspects. This question was taken from the student's pragmatics pre-test. 


\section{Scenario: GRADING TESTS}

You are a Graduate Assistant and you work for a college professor. He asks you to grade a lot of tests by tonight, but you can’t do it.

Professor: Ok, so I'm going to need you to have those tests graded by this evening.

(3) You: I'm sorry professor, but can you give me a little more time on it?

This student's answer can be examined in light of Bardovi-Harlig’s (1996) four categories in which a non-native speaker production of speech acts differs from a native speaker's (choice of speech acts, semantic formula, content, or linguistic form). If compared to the possible answers provided by the native speaking instructors who helped develop the grading criteria for the pragmatics tests in this study (see Examples 4 and 5 below), the student chose to begin his answer with the same speech act (apology) as Native Speaker 2, but failed to give a reason and compensate the person for the problem (moves that often follow an apology in English), and also used a different linguistic form ("can you" instead of "would it be possible"). Besides that, there is a difference in register: The student simply addresses the professor as “professor”, while the native speaker opted for “sir/ma'am”. Even though Native Speaker 1's main speech act was a request, he also offers a reason for not being able to grade the tests and a promise to have it done by another time (and did not just ask for an extension).

Professor: Ok, so I'm going to need you to have those tests graded by this evening. (4) You: (Native Speaker 1) Is it ok if I hand it in first thing tomorrow? I will be unable to give them a thorough and complete look by tonight, but I can assure a satisfactory job by tomorrow.

(5) You: (Native Speaker 2) I'm sorry sir/ma'am, but I have a big test to study for tonight. Would it be possible to get them to you by tomorrow evening? 
The second main goal of this project was to investigate the effectiveness of instruction in interlanguage pragmatics in an ESL setting. The materials and assessments designed for this study focused primarily on the comprehension and production of five speech acts (requests, refusals, apologies, compliments, and suggestions). The instructional treatment aimed at developing students' pragmatic competence, through explicit and formal instruction of English pragmatics and the lessons consisted of awareness raising activities, discussions based on contrastive analysis, recognition of pragmatic infelicities, and production of socially appropriate language.

Although the comparison and experimental groups were matched based on their language proficiency, the comparison group ended up much higher in language proficiency than the experimental group, due to participant attrition. When language proficiency was used as a covariate in the analyses, we found that the two groups were not significantly different in pragmatic ability at pre-test, indicating significant growth at post-test and delayed post-test, but the experimental group performed significantly better than the comparison group.

A further analysis of the development within the experimental group offers supporting evidence for instructed interlanguage pragmatics based on the significant improvements seen between pre-tests and immediate post-test and pre-test and delayed post-test. In other words, the experimental group did significantly better in their pragmatics post-test and delayed post-test than in the pre-test, indicating significant instructional effect and retention of effect. Examples (6), (7), and (8) were taken from the pragmatics pre-, post-, and delayed post-test of the same student in the experimental group. This student's score on the language proficiency test was 24\%. All examples below involve an academic situation with a professor, in which the student had to perform two main speech acts, namely apology and request. 


\section{Pre-Test:}

\section{Scenario: LATE ASSIGNMENT}

You have turned in a project for your class late for the second time. Your teacher had already given you one chance of forgiveness and you need to explain to him why you deserve another chance.

Teacher: I'm not going to accept this assignment because I've already given you a chance.

(6) You: Yes, that it's true. But it's out of my hands the situation that I had today.

\section{Post-Test:}

Scenario: NOT READY

It is your day to give your talk in class, but you are not ready.

Teacher: Thank you Steven, that was very interesting. Now it's your turn to give your talk.

(7) You: I'm really sorry but I'm not ready. If it is not a problem, could you give me a chance another day? Please.

\section{Delayed Post-Test:}

Scenario: HOMEWORK

You didn't turn in your homework assignment on the day it was due because you missed that class. You would like to see if you could still hand it in. You go to your teacher's office.

You: (knock on the door)

Teacher: Yes, come in.

(8) You: Hello, Mrs. Smith, I'm sorry I was absent last class; I had a doctor's appointment during class time. That was the reason why I didn't turn in my homework. May I have another opportunity to turn it in?

This student's answers demonstrate changes in the strategies in the speech acts of apology and request. In Example (6), even though the students admits her wrongdoing, she doesn't express her regret or sorrow, doesn't offer a reason good enough for this type of situation 
(in which one would expect a more detailed explanation), and doesn’t make any promise to change her behavior and not let the action happen again. In Example (7), no explanation as to why she was not ready is given, but the student expresses her sorrow and the linguistic forms she chooses not only show more respect and formality but also soften the request by making it less direct or commanding ("If it is not a problem, could you...”). The answer taken from the delayed post-test (Example 8), shows a more complete accomplishment of an apology and a request in terms of the moves that are usually found in English. Her answer consists of an expression of apology, a detailed explanation for missing class and not turning in the homework assignment, and a formal request to be able to still turn it in.

Additional analysis of follow-up conversations with some IEP instructors and students who belonged to the experimental group also contributed positively to the assumption that instruction on interlanguage pragmatics can be beneficial, especially in terms of increasing students’ awareness of pragmatic aspects of language use. This is particularly true for learners of lower proficiency levels, who still did not have a sufficient control of many linguistic forms, but at least became aware that how they convey their message is influenced by their choice of words and structure. These students also seemed to rely more on formulaic expressions at the end of the research study.

The results of this research study not only provide supporting evidence for previous research findings of other studies that advocate for direct instruction in pragmatics, but they also call attention to the fact that ESL learners can also benefit from it. In fact, Jeon and Kaya's (2006, p. 169) reasoning behind the necessity of pragmatics instruction is that it "facilitates more efficient acquisition of certain areas of L2 pragmatics which are difficult to learn only through exposure”, and can be applied to both environments - EFL and ESL. 
In summary, the better performance of the students in the experimental group demonstrates that direct instruction has positive effects on pragmatic acquisition. Based on students' delayed post-test scores, we can also see that what students learned was carried on over time and tends to keep increasing. Kasper (1997) may be right that pragmatic competence itself cannot be taught, but I also believe that teachers can - and should - help students develop their pragmatic competence, first, by making them aware of the pragmatics aspects of a language through discussion of authentic language use and how speakers accomplish their goals and, second, by providing many opportunities for practice. Since it is impossible to cover in the classroom all the innumerous situations a student may encounter in the target language environment, by making students aware of the fact that language should not be used or understood in isolation (i.e., speakers say and interpret utterances according to the context where they are inserted) and teaching them that they should make different linguistic choices based on that assumption, teachers are certainly helping students become more successful second language speakers and writers.

\subsection{Limitations of the Study}

A major limitation of this study is related to the nature of the participant population, which was fairly homogeneous in terms of language background and gender. There were 31 male participants but only 8 female participants, and only one female was present in the experimental group, and the participants involved in this study were predominantly from Arabic L1 backgrounds. Initially, this study attempted to control potential extraneous variables related to participants when the two groups were divided. However, due to attrition from the original enrollment (of approximately 45\%), it became impossible to have two completely comparable 
groups in terms of same number of participants, gender, language background, and level of English proficiency.

Due to administrative issues, and in an attempt to discourage student attrition as much as possible, this study was conducted over a period of five weeks, including the data collection procedures and the instructional treatment. The post-test was administered one day after the completion of the treatment, and the delayed post-test only a week afterwards. Thus, it would be misleading to conclude that the results can be interpreted to mean that the treatment also had long-term effects.

Moreover, the language proficiency test did not measure students’ ability to speak, listen and write in English. It would be an incorrect assumption to affirm that their overall proficiency level corresponded exactly to their scores on the test developed for this study.

Also concerning the instruments, pragmatic competence was operationalized in terms of learners' recognition of pragmatic infelicities, and comprehension and production of five speech acts. However, pragmatic ability involves other communication skills, such as conversational management, conversational openings and closings, face-threatening acts, and both conventional and non-conventional implicatures. Another aspect that has to be taken into consideration is the fact that, although during the instructional treatment students learned that using pragmatically appropriate language means being able to choose to be polite or rude depending on the context, the students were only expected to choose the most appropriate answers on the tests based on politeness (i.e., answers were not considered appropriate if they were too polite or rude). In addition, assessing students’ pragmatics skills only based on their performance on discourse judgment tasks, multiple-choice discourse completion tasks and written discourse completion tasks may not accurately reveal their overall pragmatic ability, but the practicality of 
administration and easiness in scoring of these types of tasks prevailed over other assessment tasks, such as oral discourse completion tasks, discourse role-play tasks, and discourse selfassessment tasks.

The limitations of this current study, however, are not uncommon to other instructional studies. Researchers in instructed pragmatics have been facing similar issues and challenges (Billmyer, 1990a, 1990b; Bouton, 1994a; Fukuya, 1998; Fukuya et al., 1998; Martínez-Flor \& Soler 2007; Morrow, 1996; Taguchi, 2003; Vellenga, 2008). However, these issues will have to be addressed in future research.

\subsection{Pedagogical Implications}

This study can contribute to the increasing body of research on instructed pragmatics by providing detailed description of assessment of pragmatic ability and of an instructional treatment to learners in an ESL setting. Teachers and researchers alike may find that the topics and findings reported and discussed here can help them get a better understanding of second language learners’ pragmatic competence and development through instruction.

This study supports previous research in the area of second language acquisition which suggests that instruction does make a difference (e.g., Martínez-Flor \& Soler, 2007; Rose \& Kasper, 2001) and it also offers ideas and suggestions of how pragmatics features can be taught and assessed in order to facilitate learners' pragmatic development. Appendix J shows a sample syllabus for a semester-long course on pragmatics that was derived from the results of this research and may be used as a resource for other teachers. Although this syllabus was designed for an elective course whose content was only pragmatics, it is possible to incorporate pragmatics instruction into the language teaching syllabus, along with grammatical instruction. 
Teachers can, for instance, provide more contextualized activities in terms of who is speaking to whom, where the situation is taking place, and what is being said; basically, what the speaker intends to accomplish when uttering/writing a particular sentence. This way, students' attention will be drawn to the fact that the way speakers say and interpret things depends on a number of factors that must not be overlooked by the language learner. Non-native speaking teachers can also provide students with authentic examples of the instructor's own successes and failures when communicating in the target language.

Furthermore, as I observed during the instruction for this study, students appeared to be much more engaged in the process of learning other linguistic features (such as pronunciation, intonation, lexicon, syntax) when they were aware of the reasons why one would choose a particular form over the other and how those choices affected the outcomes of a communicative interaction. In my experience as a teacher, I have often noticed that when students learn a linguistic form that performs a certain function (such as the use of the modal "can” to request something), they tend not to be so interested in learning other forms that could perform the same function, just because they already knew one way of doing it (and apparently needed to "save storage space in their brain” for new rules).

Thus, having students perform different roles not only showed them the importance of knowing different linguistic forms to perform language functions, but also brought clear changes to their discourse. The more knowledgeable they became about the pragmatic aspects of English, the more confident they seemed to be with using the language in more creative ways as well, not only sticking to the basic forms they had learned so far. Students definitely appeared to be more willing to take risks and to try out new forms to accomplish their communicative goals more successfully - and more naturally. 


\subsection{Future Research Directions}

Directions for future research are proposed below in order to address the limitations of this study. First, conducting an instructional study either over a longer period of time (a semester or a year, for instance) and/or administering an additional measurement with an appropriate time interval could shed more light into the learners’ pragmatic development.

Administering a language proficiency test that measures students’ speaking and listening skills would also be important, since the main focus of pragmatics instruction is geared towards improving students' oral communication skills. Thus, it could be more realistic to assign students into groups according to their oral ability as well.

Using different elicitation tasks (such as oral discourse completion tasks, discourse roleplays, and self-assessment tasks) can also provide a different insight into learners' pragmatic awareness and their development overtime. In addition, future research studies should consider including a post-data collection formal instrument (such as a self-reflective survey or an interview) to gather information from the participants in the experimental group with regards to their perceptions of whether instruction helped them develop their awareness of pragmatic aspects of language use.

Future research may also want to measure to what extent the length of stay in the L2 environment influences instructed pragmatic development in an ESL setting in comparison to level of language proficiency. Some previous studies have shown, for example, that the longer the participants stayed, the longer their utterances were (Blum-Kulka \& Olshtain, 1986), the better they interpreted implicatures (Bouton, 1992, 1994a, 1994b) and used highly salient conversational functions such as greetings (Omar, 1991, 1992). 
Data collected from a larger sample of male and female participants of different language backgrounds can also provide more thorough information with respect to what extent gender plays a role in pragmatic proficiency and what specific features are positively or negatively transferred from a particular L1.

\subsection{Closing Remarks}

Many research studies, along with this present one, have provided empirical evidence to support the reasoning behind the fact that second language learners will encounter problems interpreting and expressing meaning in the target language that may be derived not only from lack of grammatical, lexical, phonological, and/or semantic knowledge but also from lack of pragmatic knowledge.

Considering that the teacher's role is to help L2 learners improve their communicative competence, the development of pragmatic ability can by no means be ignored, since it is one of the important components in successful communication. As LoCastro (2003, p. 313) points out, “even in our first language, to present ourselves as we wish requires comprehending and producing pragmatic meanings in a variety of contexts, ranging from a simple speech act requesting the salt to processing irony and comprehending joking.”

Thus, incorporating pragmatics instruction to the core curriculum can only assist teachers in the process of helping students expand their knowledge of how language is used in situationally and culturally appropriate ways. Developing students’ pragmatics awareness, or the way speakers do things with words in a given speech community, is enabling them to carry on authentic communication in the real world, through dialogue, interaction, and engagement of all parts involved. 
Based on Vygotsky’s sociocultural theory (1986) in which learning is socially situated and language is seen as a tool that mediates between individuals and their environment, it becomes essential that students learn not only how to interact with the teacher and with their peers, but also with the outside world. This is not to say that students must choose to emulate native speaker behavior in order to be able to communicate effectively in the target language environment. They need to know, however, how the linguistic choices they make can influence their communication as a whole. Cohen (2008, p. 215), for example, is “especially concerned with helping L2 learners avoid pragmatic failure in high-stakes situations where they must interact with native speakers of the L2 and where approximating the sociocultural norms for the given context norms is a priority.” Wall (1990, p. 81) shares a similar opinion, and adds that "we want our students to be able to face uncomfortable social situations without fear that they will say the wrong thing.”

Bringing pragmatics into the ESL classroom is not an easy task, though. We first need to consider the nature of the student population. Students who are learning a new language are certainly not part of a homogeneous group, especially the ones learning English as a second language. Not only do the members of this group differ in many ways, such as different cultural background, native language, socio-economic situation, world knowledge, motivation to learn English, but they also show many levels of communicative ability (such as levels of oral proficiency, literacy abilities, and pragmatic skills) even when they are placed in the same classroom. In addition, while some of these learners might come from languages that share similar pragmalinguistic and sociopragmatic aspects to the L2, others might come from a totally different background. 
Nonetheless, diversity can be seen as a resource and not a problem, especially when it comes to teaching pragmatics. Since the input learners usually get in the classroom come from the teacher, from the materials, and from their peers, the more diverse the students are, the richer the source of input will be. Thus, providing awareness-raising and discussion activities and a variety of opportunities for practice are ways of reaching - and teaching - all the learners in the classroom. Besides, the technology available nowadays can also be very useful in terms of providing appropriate input and examples of authentic language use. The internet, for example, offers not only a wide variety of spoken situations such as online videos, clips of TV shows, movies, and sitcoms, but is also a great source of samples of genuine written material, such as emails, blogs, and news (see Rose, 2001, for a study that discusses the use of film as a resource for pragmatics research and language teaching; and Cohen, 2008, for a discussion about the role of technology in making L2 pragmatics accessible to learners).

It is also important to remember that culture, language, and identity are related, and building upon students’ cultural experiences and background becomes essential in order to facilitate the learning process and make it more meaningful. In order to do so, encouraging students to relate what they are learning to their personal experiences or to their native language is crucial. For example, when they study how to request something or pay somebody a compliment in English, asking them to explain how they would do it in their native language or in which situations they would perform these speech acts can not only help them notice how they are being perceived by the target language community but also give them the tools to be able to make conscious linguistic choices.

Moreover, stimulating critical thinking, further reading on a topic, and application of knowledge increases students' participation and engagement in the process of learning in 
general. Thus, it is essential to value intellectually challenging learning as opposed to what had traditionally been the focus of some programs for language learners (which were usually defined by lower-level drill-and-practice activities, vocabulary and grammar learning out of context, and endless worksheets). The activities done in class should be aimed at providing students with opportunities for meaningful exchange of language, which also turns out to be a very good way to keep students interested and motivated. To illustrate, one activity that can be done with college-age ESL students living in the United States involves learning the language and communicative strategies they need to speak to their landlords about problems in their apartments. Even if they don't have any complaints at the moment, they have to work on types of problems they might/could encounter and how to go about solving them by talking to the landlord/owner of the house/host family/roommate. It is a great way of teaching them not only vocabulary and grammar structures, but also pragmatics - since they have to perform role-plays as well, they have to know what to say to whom and how (talking to a landlord, for example, is different than talking to a roommate).

Finally, another aspect that certainly cannot be ignored when bringing pragmatics into the classroom is that the teachers themselves must know about pragmatics aspects of language use. Rose (1997) argues that teacher education should include a course on the pragmatics aspects of the language the teachers are going to teach, just as it includes courses on the grammatical aspects of that language. However, he draws attention to the fact that teaching pragmatics is not as straightforward as the teaching of grammar, because one could not equip teachers "with all of the pragmatic facts of a language, as they would be exposed to in preparing to teach grammar” (p. 132). Since it is impossible to anticipate all the language and cultural situations a non-native speaker will encounter and teach them everything they need to know when communicating in the 
target language, the alternative Rose proposes is to apply a consciousness-raising approach to teacher education, which he calls pragmatic consciousness-raising (PCR). This alternative focuses on familiarizing teachers with pragmatics theory and research, encouraging them to “conduct pragmatic analysis of their own, and ultimately helping language learners to do the same” (p. 132). While the approach suggested by Rose is mostly geared towards non-native speaking teachers (who can’t be expected to behave as a native speaker), native speaking teachers can benefit from it as well, especially since they tend to rely much more on intuition when it comes to the rules of language use. As LoCastro (2003, p. viii) puts it, “for language educators, a solid knowledge of pragmatics is crucial in developing successful second and foreign language speakers and writers.” 


\section{References}

Austin, J. L. (1962). How to do things with words. Cambridge, MA: Harvard University Press.

Bachman, L. (1990). Fundamental considerations in language testing. Oxford: Oxford University Press.

Bachman, L., \& Palmer, A. (1996). Language testing in practice: Designing and developing useful language tests. Oxford: Oxford University Press.

Bardovi-Harlig, K. (1996). Pragmatics and language teaching: Bringing pragmatics and pedagogy together. In L. Bouton (Ed.), Pragmatics and language learning (pp. 21-39). Urbana-Champaign: University of Illinois, Division of English as an International Language.

Bardovi-Harlig, K. (1999). Exploring the interlanguage of interlanguage pragmatics: A research agenda for acquisitional pragmatics. Language Learning, 49(4), 677-713.

Bardovi-Harlig, K. (2002a, April). The interlanguage of interlanguage pragmatics: The case of future modals. Paper presented at the annual meeting of the American Association of Applied Linguists, Salt Lake City, UT.

Bardovi-Harlig, K., \& Dörnyei, Z. (1998). Do language learners recognize pragmatic violations? Pragmatic versus grammatical awareness in instructed L2 learning. TESOL Quarterly, 32, 233-262.

Bardovi-Harlig, K., \& Griffin, R. (2005). Pragmatic awareness: Evidence from the ESL classroom. System, 33, 401-415.

Bardovi-Harlig, K., \& Hartford, B. (1993). Learning the rules of academic talk: A longitudinal study of pragmatic change. Studies in Second Language Acquisition, 15, 279-304. 
Bialystok, E. (1993). Symbolic representation and attentional control in pragmatic competence. In G. Kasper \& S. Blum-Kulka (Eds.), Interlanguage Pragmatics (pp. 43-59). New York: Oxford University Press.

Billmyer, K. (1990a). The effect of formal instruction on the development of sociolinguistic competence: The performance of compliments. Unpublished doctoral dissertation, University of Pennsylvania, Philadelphia.

Billmyer, K. (1990b). “I really like your lifestyle”: ESL learners learning how to compliment. Penn Working Papers in Educational Linguistics, 6, 31-48.

Blum-Kulka, S. (1982). Learning to say what you mean in a second language: A study of speech act performance of learners of Hebrew as a second language. Applied Linguistics, 3, 2959.

Blum-Kulka, S. (1991). Interlanguage pragmatics: The case of requests. In R. Phillipson, E. Kellerman, M. Sharwood Smith, and M. Swain (Eds.), Foreign/second language pedagogy research (pp. 255-272). Clevedon: Multilingual Matters.

Blum-Kulka, S., House, J., \& Kasper, G. (1989). Investigating cross-cultural pragmatics: An introductory overview. In S. Blum-Kulka, J. House, and G. Kasper (Eds.), Cross-cultural pragmatics: Requests and language learning. Norwood, NJ: Ablex.

Blum-Kulka, S., \& Olshtain, E. (1986). Too many words: Length of utterance and pragmatic failure. Studies in Second Language Acquisition, 8, 165-180.

Bouton, L. (1992). The interpretation of implicature in English by NNS: Does it come automatically - without being explicitly taught? In L. Bouton and Y. Kachru (Eds.), Pragmatics and language learning, monograph series vol. 3 (pp. 53-65). Urbana- 
Champaign: Division of English as an International Language, University of Illinois, Urbana-Champaign.

Bouton, L. (1994a). Can NNS skill in interpreting implicatures in American English be improved through explicit instruction? A pilot study. In L. Bouton and Y. Kachru (Eds.), Pragmatics and language learning, monograph series vol. 5 (pp. 88-109). Urbana-Champaign:

Division of English as an International Language, University of Illinois, UrbanaChampaign.

Bouton, L. (1994b). Conversational implicature in the second language: Learned slowly when not deliberately taught. Journal of Pragmatics, 22, 157-167.

Boxer, D. (1993). Complaints as positive strategies: What the learner needs to know. TESOL Quarterly, 27, 277-299.

Brown, J. D. (2001). Pragmatics tests: Different purposes, different tests. In K. R. Rose, and G. Kasper (Eds.), Pragmatics in language teaching (pp. 301-325). New York: Cambridge University Press.

Brown, P., \& Levinson, S. (1987). Politeness: Some universals in language usage. Cambridge: Cambridge University Press.

Canale, M., \& Swain, M. (1980). Theoretical bases of communicative approaches to second language teaching and testing. Applied Linguistics, 1, 1-47.

Carrell, P. L., \& Konneker, B. H. (1981). Politeness: Comparing native and non-native judgment. Language Learning, 31(1), 17-30.

Cohen, A. D. (1996). Developing the ability to perform speech acts. Studies in Second Language Acquisition, 18, 253-267. 
Cohen, A. D. (2004). Assessing speech acts in a second language. In Boxer and A. Cohen (Eds.), pp. 302-327.

Cohen, A. D. (2005). Strategies for learning and performing L2 speech acts. Intercultural Pragmatics, 2-3, 275-301.

Cohen, A. D. (2008). Plenary speeches: Teaching and assessing L2 pragmatics: What can we expect from learners? Language Teaching, 41(2), 213-235.

Crystal, D. (1985). A dictionary of linguistics and phonetics. 2nd edition. Oxford: Blackwell.

Crystal, D. (Ed.). (1997). The Cambridge encyclopedia of language. 2nd edition. New York: Cambridge University Press.

Dewey, D. (2004). A comparison of reading development by learners of Japanese in intensive domestic immersion and study abroad contexts. Studies in Second Language Acquisition, 26, 303-327.

Ellis, R. (1992). Learning to communicate in the classroom: A study of two learners' requests. Studies in Second Language Acquisition, 14, 1-23.

Flowerdew, J. (1990). Problems of Speech Act Theory from an applied perspective. Language Learning, 40, 79-105.

Fukuya, Y. (1998). Consciousness-raising of downgraders in requests. Paper presented at Second Language Research Forum, University of Hawai’i, Manoa, October.

Fukuya, Y., \& Clark, M. (in press). Input enhancement of mitigators. In L. Bouton (Ed.), Pragmatics and language learning, monograph series vol. 10. Urbana-Champaign: Division of English as an International Language, University of Illinois, UrbanaChampaign. 
Fukuya, Y., Reeve, M., Gisi, J., \& Christianson, M. (1998). Does focus on form work for sociopragmatics? Paper presented at the $12^{\text {th }}$ Annual International Conference on Pragmatics and Language Learning, University of Illinois, Urbana-Champaign, April.

Gass, S. M., \& Selinker, L. (2008). Second language acquisition: An introductory course. 3rd edition. New York: Routledge.

Goffman, E. (1976). Replies and responses. Language in Society, 5, 257-313.

Grant, L., \& Starks, D. (2001). Screening appropriate teaching materials: Closings from textbooks and television soap operas. International Review of Applied Linguistics in Language Teaching, 39, 39-50.

Grice, P. (1975). Logic and conversation. In P. Cole and J. Morgan (Eds.). Syntax and semantics, Volume 3: Speech Acts (pp. 41-58). New York: Academic Press.

Hinkel, E. (2001). Building awareness and practical skills to facilitate cross-cultural communication in ESL/EFL (3rd ed.). In M. Celce-Murcia (Ed.), Teaching English as a second or foreign language (pp. 443-458). Heinle \& Heinle.

House, J. (1996). Developing fluency in English as a foreign language: Routines and metapragmatic awareness. Studies in Second Language Acquisition, 18(2), 225-252.

Hymes, D. (1972). On communicative competence. In J. B. Pride \& J. Holmes (Eds.), Sociolinguistics: Selected readings (pp. 269-293). Harmondsworth, England: Penguin.

Jeon, E. H., \& Kaya, T. (2006). Effects of L2 instruction on interlanguage pragmatic development: A meta-analysis. In J. M. Norris and L. Ortega (Eds.), Synthesizing research on language learning and teaching (pp. 165-211). John Benjamins Publishing Company. Jiang, X. (2006). Suggestions: What should ESL students know? System, 34(1), 36-54. 
Kasper, G. (1997). Can pragmatic competence be taught? (NetWork \#6) [HTML document]. Honolulu: University of Hawai’i, Second Language Teaching \& Curriculum Center. Retrieved October 12, 2012 from the World Wide Web: http://www.nflrc.hawaii.edu/NetWorks/NW06/

Kasper, G. (2001). Classroom research on interlanguage pragmatics. In K. R. Rose, and G. Kasper (Eds.), Pragmatics in language teaching. (pp. 33-60). New York: Cambridge University Press.

Kasper, G., \& Rose, K. R. (1999). Pragmatics and SLA. Annual Review of Applied Linguistics, 19, 81-104.

Kasper, G., \& Schmidt, R. (1996). Developmental issues in interlanguage pragmatics. Studies in Second Language Acquisition, 18(2), 149-169.

Kehe, D., \& Kehe, P. D. (2009). Conversation strategies. Brattleboro, Vermont: Pro Lingua Associates.

Kitao, K. (1990). A study of Japanese and American perceptions of politeness in requests. Doshida Studies in English, 50, 178-210.

Koike, D. A. (1996). Transfer of pragmatic competence and suggestions in Spanish foreign language learning. In S. M. Gass \& J. Neu (Eds.), Speech acts across cultures (Vol. 11, pp. 257-281). Berlin: Mouton de Gruyter.

Kubota, M. (1995). Teachability of conversational implicature to Japanese EFL learners. IRLT Bulletin, 9, 35-67.

Leech, G. (1983). The principles of pragmatics. London: Longman.

Levinson, S. C. (1983). Pragmatics. Cambridge: Cambridge University Press. 
Li, D. (2000). The pragmatics of making requests in the L2 workplace: A case study of language socialization. The Canadian Modern Language Review/La Revue Canadienne des Langues Vivantes, 57(1), 58-87.

Lin, H. H. (2005). Contextualizing linguistic politeness in Chinese - A socio-pragmatic approach with examples from persuasive sales talk in Taiwan Mandarin. Dissertation Abstracts International, 66(01). (UMI No. 3160830)

LoCastro, V. (2003). An introduction to pragmatics: Social action for language teachers. Ann Arbor: University of Michigan Press.

Long, M., Adams, L., McLean, M., \& Castanos, F. (1976). Doing things with words: Verbal interaction in lockstep and small group classroom situations. In J. Fanselow \& R. Crymes (Eds.), On TESOL '76 (pp. 137-153). Washington, DC: TESOL.

Lyster, R. (1994). The effect of functional-analytic teaching on aspects of French immersion students’ sociolinguistic competence. Applied Linguistics, 15, 263-287.

Maeshiba, N., Yoshinaga, N., Kasper, G., \& Ross, S. (1996). Transfer and proficiency in interlanguage apologizing. In S. Gass \& J. Neu (Eds.), Speech acts across cultures (pp. 155-187). Berlin: Mouton de Gruyter.

Martínez-Flor, A., \& Soler, E. A. (2007). Developing pragmatic awareness of suggestions in the EFL classroom: A focus on instructional effects. Canadian Journal of Applied Linguistics, 10, 47-76.

Martínez-Flor, A., \& Uso-Juan, E. (2006). A comprehensive pedagogical framework to develop pragmatics in the foreign language classroom: The 6 Rs approach. Applied Language Learning, 16(2), 39-64. 
Matsumura, S. (2001). Learning the rules for offering advice: A quantitative approach to second language socialization. Language Learning, 51(4), 635-679.

Matsumura, S. (2003). Modeling the relationships among interlanguage pragmatic development, L2 proficiency and exposure to L2. Applied Linguistics, 24(4), 465-491.

Mey, J. L. (1993). Pragmatics: An introduction. Oxford: Blackwell.

Morrow, C. (1996). The pragmatic effects of instruction on ESL learners’ production of complaint and refusal speech acts. Unpublished doctoral dissertation, State University of New York at Buffalo.

Ochs, E. (1996). Linguistic resources for socializing humanity. In J. J. Gumperz and S. L. Levinson (Eds.), Rethinking linguistic relativity (pp. 407-437). Cambridge: Cambridge Universtiy Press.

Olshtain, E., \& Blum-Kulka, S. (1985). Degree of approximation: Nonnative reactions to native speech act behavior. In S. M. Gass \& C. G. Madden (Eds.), Input in second language acquisition (pp. 303-325). Rowley, MA: Newbury House.

Omar, A. (1991). How learners greet in Kiswahili: A cross-sectional survey. In L. Bouton and Y. Kachru (Eds.), Pragmatics and language learning, monograph series vol. 2 (pp. 59-73). Urbana-Champaign: Division of English as an International Language, University of Illinois, Urbana-Champaign.

Omar, A. (1992). Opening and closing conversations in Kiswahili: A study of the performance of native speakers and learners. Unpublished doctoral dissertation, Indiana University, Bloomington. 
Pearson, L. (1998). Spanish L2 pragmatics: The effects of metapragmatic discussion. Paper presented at the Second Language Research Forum, University of Hawai i, Manoa, October.

Philips, D. (2003). Longman preparation course for the TOEFL test: The paper test. White Plains, NY: Pearson Longman.

Poole, D. (1992). Language socialization in the second language classroom. Language Learning, 42, 593-616.

Roever, C. (2004). Difficulty and practicality in tests of interlanguage pragmatics. In Boxer \& Cohen (Eds.), 283-301.

Rose, K. (1997). Pragmatics in teacher education for nonnative-speaking teachers: A consciousness-raising approach. Language, Culture \& Curriculum, 10(2), 125-138.

Rose, K. (2001). Compliments and compliment responses in film: Implications for pragmatics research and language teaching. IRAL, 39, 309-326.

Rose, K., \& Kasper, G. (2001). Pragmatics in language teaching. New York: Cambridge University Press.

Sacks, H., Schegloff, E., \& Jefferson, G. (1974). A simplest systematics for the organization of turn-taking in conversation. Language, 50, 696-735.

Schauer, G. (2006). Pragmatic awareness in ESL and EFL contexts: Contrast and development. Language Learning, 56, 269-318.

Searle, J. (1969). Speech acts: An essay in the philosophy of language. Cambridge: Cambridge University Press.

Searle, J. (1975). Indirect speech acts. In P. Cole and J. Morgan (Eds.), Syntax and semantics, Volume 3: Speech Acts (pp. 59-82). New York: Academic Press. 
Soler, E. A., \& Pitarch, J. G. (2010). The effect of instruction on learners’ pragmatic awareness: A focus on refusals. International Journal of English Studies, 10(1), 65-80.

Takahashi, S. (1993). Transferability of indirect request strategies. University of Hawai’i Working Papers in ESL, 1-40. Honolulu, HI: Department of English as a Second Language.

Takahashi, T., \& Beebe, L. (1987). The development of pragmatic competence by Japanese learners of English. JALT Journal, 8, 131-155.

Tanaka, S., \& Kawade, S. (1982). Politeness strategies and second language acquisition. Studies in Second Language Acquisition, 5, 18-33.

Tannen, D. (1984). Conversational style: Analyzing talk among friends. Norwood: Ablex.

Taguchi, N. (2003). Pragmatic performance in comprehension and production of English as a second language. Dissertation Abstracts International, 65(01), 134A. (UMI No. 3118493)

Taguchi, N. (2008). The role of learning environment in the development of pragmatic comprehension: A comparison of gains between EFL and ESL learners. Studies in Second Language Acquisition, 30, 423-452.

Takimoto, M. (2008). The effects of deductive and inductive instruction on the development of language learners’ pragmatic competence. The Modern Language Journal, 92, 369-386.

Tanaka, K. (2004). Changes in Japanese students’ beliefs about language learning and English language proficiency in a study-abroad context. Unpublished doctoral dissertation, University of Auckland, New Zealand.

Thomas, J. (1983). Cross-cultural pragmatic failure. Applied Linguistics, 4, 91-112.

Thomas, J. (1995). Meaning in interaction: An introduction to pragmatics. London: Longman. Tomalin, B., \& Stempleski, S. (1993). Cultural awareness. New York: Oxford University Press 
Trosborg, A. (1995). Interlanguage pragmatics: Requests, complaints, and apologies. Berlin: Mouton de Gruyter.

Vellenga, H. E. (2008). Instructional effectiveness and interlanguage pragmatics. Dissertation Abstracts International, 69(06). (UMI No. 3318496)

Vygotsky, L.S. (1986). Thought and language. Cambridge: MIT Press.

Wall, A. P. (1990). Saying it naturally. In L. F. Bouton \& Y. Kachru (Eds.), Pragmatics and Language Learning, vol. 1, (pp. 67-82). Urbana-Champaign: University of Illinois, Division of English as an International Language.

Wall, A. P. (1998). Say it naturally: Verbal strategies for authentic communication (level 1). 2ed. Boston, MA: Heinle \& Heinle.

Wall, A. P. (1998). Say it naturally: Verbal strategies for authentic communication (level 2). 2ed. Orlando, FL: Harcourt Brace \& Company.

Weasenforth, D., \& Biesenbach-Lucas, S. (2000). Please help me: L1/L2 variations in solicitations in electronic conferences. Paper presented at Second Language Research Forum 2000. Madison, Wisconsin.

Wilkins, D. (1976). Notional syllabuses. Oxford: Oxford University Press.

Yamashita, S. (1996a). Comparing six cross-cultural pragmatics measures. Unpublished doctoral dissertation, Temple University, Philadelphia.

Yamashita, S. (1996b). Six measures of JSL pragmatics (Technical Report \#14). Honolulu: University of Hawai'i, Second Language Teaching and Curriculum Center.

Yoshitake, S. (1997). Interlanguage competence of Japanese students of English: A multi-test framework evaluation. Unpublished doctoral dissertation, Columbia Pacific University, San Rafael, California. 


\section{APPENDIX A: LESSON PLANS - EXPERIMENTAL GROUP}

\section{LESSON PLAN \#1}

\section{Goals:}

- To raise learners' awareness of pragmatic differences across languages;

- To increase awareness and sensitivity to cultural differences;

- To stimulate discussion and provide opportunities for students to express their views;

- To familiarize students with metapragmatic discussion and contextual features affecting language use.

\begin{tabular}{|c|c|c|c|}
\hline Objectives (Students will be able to...) & Materials & Procedures & Time \\
\hline $\begin{array}{l}\text { - read a short passage about a critical incident } \\
\text { and come up with their own solutions to the } \\
\text { problem involved. } \\
\text { - } \text { support their answers and express their points } \\
\text { of view. } \\
\text { - compare and contrast the situation presented } \\
\text { to their native language. } \\
0 \text { discuss ways of addressing a teacher } \\
\text { in English - Handout \#1 } \\
\text { o discuss ways of accepting a } \\
\text { compliment from a teacher - Handout } \\
\# 2\end{array}$ & $\begin{array}{l}\text { Handout \#1: } \\
\text { Addressing the } \\
\text { Teacher } \\
\text { Handout \#2: } \\
\text { Accepting a } \\
\text { compliment }\end{array}$ & $\begin{array}{l}\text { Individual work } \\
\text { followed by } \\
\text { whole-class } \\
\text { discussion. }\end{array}$ & 20 min. \\
\hline $\begin{array}{l}\text { - discuss what influences the choices of certain } \\
\text { linguistic structures over others (what we say } \\
\text { to whom, how we say, why, and when). }\end{array}$ & $\begin{array}{l}\text { See Oral } \\
\text { Brainstorming } \\
\text { Section: for the } \\
\text { teacher only }\end{array}$ & $\begin{array}{l}\text { Oral } \\
\text { brainstorming } \\
\text { section: Teacher } \\
\text { poses questions } \\
\text { and invites } \\
\text { students to } \\
\text { answer; teacher } \\
\text { also suggests } \\
\text { possible answers. }\end{array}$ & 5 min. \\
\hline $\begin{array}{l}\text { - compare and contrast some examples and } \\
\text { indicate who would say each one, when, and } \\
\text { where. }\end{array}$ & $\begin{array}{l}\text { Handout \# 3: } \\
\text { Examples }\end{array}$ & $\begin{array}{l}\text { Pair-work } \\
\text { followed by } \\
\text { whole-class } \\
\text { discussion. }\end{array}$ & 15 min. \\
\hline $\begin{array}{l}\text { - compare and contrast requests and refusals (in } \\
\text { different situations) based on the level of } \\
\text { difficulty (as perceived by the students). }\end{array}$ & $\begin{array}{l}\text { Handout \#4: } \\
\text { Easy to ask or } \\
\text { Difficult to } \\
\text { ask? }\end{array}$ & $\begin{array}{l}\text { Individual work } \\
\text { followed by } \\
\text { whole-class } \\
\text { discussion. }\end{array}$ & 20 min. \\
\hline
\end{tabular}

Homework: Informal observation of natural language use:

$>$ Students will informally observe the language use going on in their classes, in their teachers' offices, around campus, or on TV. They should note, for example, how people greet each other, how they take leave of each other, how they ask for things, etc., keeping in mind the contextual features discussed in today's lesson. 


\section{Handout \# 1}

\section{ADDRESSING THE TEACHER}

Read the situation below and choose the best answers to the questions. Sometimes more than one answer is possible.

It was the first day of the English class and the teacher was introducing himself. He wrote his full name, Alan Jones, on the board and said, 'My name is Alan Jones. If you like, you can use "Mr." with my name. Now I'd like you to tell me your names. Let's start with you', he said, indicating a young woman in the front row.

The young woman answered, 'My name is Liliana Castro, but you can call me Lilly, Teacher.'

Then the teacher said, ‘OK. I’ll call you Lily, but please don’t call me “Teacher”. Please call me Alan or Mr. Jones.'

Lily looked confused, but the teacher ignored her and continued to ask the students to introduce themselves.

1 Why did Liliana call Alan Jones “Teacher”?
a. She didn't know his name.
b. She was trying to show respect.
c. She couldn't pronounce his name.
d. She felt confused.

2 Why did Alan Jones ask Liliana not to call him "Teacher"?
a. He didn't really like being a teacher.
b. He wanted to be friendly.
c. In his country, only very young students call their teacher "Teacher".
d. He though Liliana was being rude.

(Activity taken from: Tomalin, B., \& Stempleski, S. (1993). Cultural Awareness. New York: Oxford University Press.)

\section{Handout \# 1 \\ ADDRESSING THE TEACHER - Answer Key}

1. The most likely explanation is (b). In many cultures students, no matter their age, address their teachers as 'Teacher', in order to show respect.

2. The most likely explanation is (c). 


\section{Handout \# 2}

\section{ACCEPTING A COMPLIMENT}

Read the situation below and choose the best answers to the questions. Sometimes more than one answer is possible.

Linda, an American teacher in an adult class in the U.S., was speaking to Usa, one of her Thai students. She said, 'Usa, I'm very happy with your work. Your English is really improving.'

Usa looked down and said, 'Oh, no. I’m not a good student. My English is not very good.'

Linda really thought that Usa was making progress, and she wanted her to know it. She said to Usa, 'But you are a good student, and you're making excellent progress. You should be proud of your work.'

Usa responded to this remark saying, 'No, no. You are a very good teacher, but I am not a good student.' Linda didn’t know what to say, so she decided not to give Usa any more compliments.

1 Why did Usa look down when the teacher complimented her?
a. She was ashamed of her work.
b. She was embarrassed by the teacher's compliment.
c. She was trying to show respect for the teacher.
d. She didn't like the teacher.

2 Why did Linda decide not to give Usa any more compliments?
a. She decided that Usa really was not a good student.
b. Usa's behavior was disrespectful.
c. Usa didn't seem to be pleased with the compliment.
d. She expected Usa to say something like 'Thank you.'

(Activity taken from: Tomalin, B., \& Stempleski, S. (1993). Cultural Awareness. New York: Oxford University Press.)

\section{Handout \# 2 \\ ACCEPTING A COMPLIMENT - Answer Key}

1. The most likely explanations are (b) and (c). Usa may have felt uncomfortable at being singled out for such a compliment, and looking down is a mark of respect in many cultures.

2. The most likely explanations are (c) and (d). It is normal for teachers in English-speaking countries to compliment students for good work, and for students to take the compliment with a 'Thank you.' 


\section{Oral Brainstorming Section: (for the teacher only)}

During conversation, what do you think are some of the things that influence what we say and how we say it?

(Possible answers)

1. Who it is we're talking to and our relationship to them.

2. Where the communication's taking place.

3. The feelings of the other person.

4. The impression we want to give of ourselves.

5. The kind of image we want to project.

6. Our purpose in communicating.

7. What has been said previously in the conversation.

8. How much we want to share with the person we're talking to.

9. Our attitude or emotional state at the time.

Follow-up question: How do these things affect what we say and how we say it?

(Possible answers)
a. They sometimes affect the amount we say.
b. They may affect how direct we are.
c. We might not say exactly what we feel.
d. We may lie or be dishonest.
e. Our language might be more formal or more casual, depending.
f. We may be vague or deliberately unclear.

\section{Handout \# 3}

In pairs, compare the following examples. Who would say each one? When? Where?

Example A: Can you take me to store? I need some groceries.

Example B: I need some groceries, but I don't have a ride to the store.

Example C: Are you busy? I have to ask you something now.

Example D: I am sorry to bother you, but I have an important question. When do you think you might have time to talk with me?

Example E: I feel terrible about being late for the meeting. I was stuck in traffic.

Example F: I can't lend you my notes because I need them tonight to study. Maybe next time.

Example G: I was late to class because of a problem.

Adapted from: Vellenga, H. E. (2008). Instructional effectiveness and interlanguage pragmatics. Dissertation Abstracts International, 69(06). (UMI No. 3318496) 


\section{Handout \# 4 Easy to ask or difficult to ask?}

Please read each question and indicate your response by circling the number from 1 to 7 .

1. Compared with "asking a friend for a pen", how easy/difficult is "asking a friend for a piece of paper” for you?

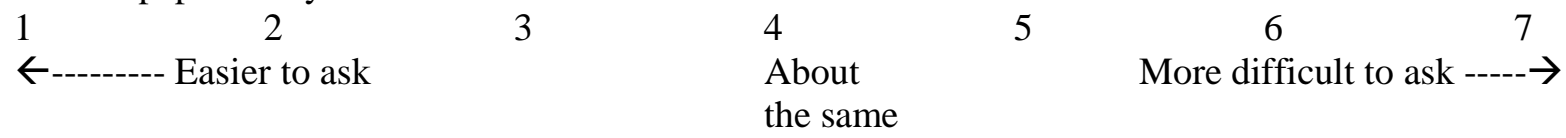

2. Compared with "asking a friend for a pen", how easy/difficult is "asking your teacher to reschedule the exam because you need to attend your good friend's wedding?”

$\begin{array}{ccccc}1 & 2 & 3 & 5 & 6\end{array}$

3. Compared with "asking a friend for a pen", how easy/difficult is "asking your sister to pass the TV remote control?”

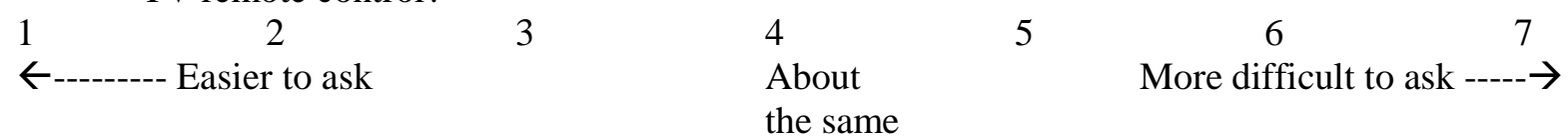

4. Compared with "asking a friend for a pen”, how easy/difficult is "asking your boss at a part-time job to give you Saturday off because you want to go camping with your friends?”

$\begin{array}{cccccc}1 & 2 & 3 & 4 & 6 & 7 \\ \leftarrow-------- \text { Easier to ask } & & \begin{array}{l}\text { About } \\ \text { the same }\end{array} & & \text { More difficult to ask }-----\rightarrow\end{array}$

5. Compared with "asking a friend for a pen”, how easy/difficult is "asking your teacher to proofread your three-page essay?”

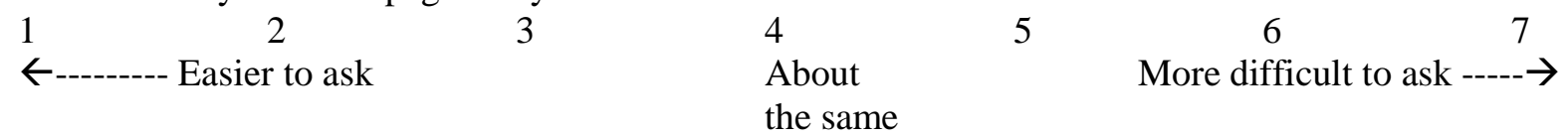

6. Compared with "refusing an offer of coffee from your friend (Your friend is asking you if you want a cup of coffee), how easy/difficult is "refusing your friend's invitation to the movie because you have to study for tomorrow's exam?”

$\begin{array}{cclcc}1 & 2 & 4 & 5 & 6 \\ & 3 & \begin{array}{l}\text { About } \\ \text { the same }\end{array} & & \text { More difficult to ask ----- } \rightarrow\end{array}$

7. Please imagine that your teacher is suggesting that you should take summer session because your grades are low. Compared with "refusing an offer of coffee from your friend", how easy/difficult is "refusing your teacher's suggestion because you already have plans?"
1
2
3
4
About
6 7
$\leftarrow---------$ Easier to ask the same

Adapted from: Taguchi, N. (2003). Pragmatic performance in comprehension and production of English as a second language. Dissertation Abstracts International, 65(01), 134A. (UMI No. 3118493) 


\section{LESSON PLAN \#2}

\section{Goals:}

- To raise students' awareness of pragmatic aspects of language use by looking at naturaloccurring data;

- To help learners understand why and when certain linguistic practices take place;

- To practice requesting and responding appropriately in different contexts.

\begin{tabular}{|c|c|c|c|}
\hline Objectives (Students will be able to...) & Materials & Procedures & Time \\
\hline $\begin{array}{l}\text { - discuss the notes they’ve taken in their } \\
\text { homework assignment in terms of } \\
\text { metapragmatic features. } \\
\text { - examine their impressions of speakers. }\end{array}$ & $\begin{array}{l}\text { Students' } \\
\text { notes. }\end{array}$ & $\begin{array}{l}\text { Whole-class } \\
\text { discussion. }\end{array}$ & $\begin{array}{l}\text { Approx. } \\
\text { 15min. }\end{array}$ \\
\hline $\begin{array}{l}\text { - listen and explain the differences in three } \\
\text { requests. } \\
\text { - list some different ways of making } \\
\text { requests. } \\
\text { - } \begin{array}{l}\text { support their linguistic choices when } \\
\text { making requests. }\end{array}\end{array}$ & $\begin{array}{l}\text { Handout \#5: } \\
\text { Making } \\
\text { Requests }\end{array}$ & $\begin{array}{l}\text { Individual, pair- } \\
\text { work, and } \\
\text { whole-class } \\
\text { discussion. }\end{array}$ & 15 min. \\
\hline $\begin{array}{l}\text { - make requests to borrow, have, or use } \\
\text { some items. } \\
\text { - request some type of action. }\end{array}$ & $\begin{array}{l}\text { Handout \# 6: } \\
\text { Requesting }\end{array}$ & $\begin{array}{l}\text { Individual } \\
\text { work. Teacher } \\
\text { walks around } \\
\text { the room to give } \\
\text { help as needed. }\end{array}$ & 15 min. \\
\hline $\begin{array}{l}\text { - make and respond to requests (accepting } \\
\text { and refusing). }\end{array}$ & $\begin{array}{l}\text { Handout \#7: } \\
\text { Role-Play }\end{array}$ & $\begin{array}{l}\text { Controlled role- } \\
\text { play activity. }\end{array}$ & $10 \mathrm{~min}$. \\
\hline $\begin{array}{l}\text { - analyze a situational dialogue and discuss } \\
\text { ways of changing it under different } \\
\text { circumstances. }\end{array}$ & $\begin{array}{l}\text { Handout \#8: } \\
\text { Situational } \\
\text { Dialogue }\end{array}$ & Whole-class. & $5 \mathrm{~min}$. \\
\hline
\end{tabular}




\section{Handout \# 5}

\section{Making Requests}

Look at and listen to the differences in these three requests:

Bob: Bring in the paper when you come back.

Sam: Bring in the paper when you come back, would you?

Tom: Would you mind bringing in the paper when you come back from running?

What differences can you see? In which situations would these speakers most likely utter these sentences? Make some notes and discuss your ideas with a classmate.

How do you usually ask... someone for something? ... someone to do something? ... someone to stop doing something? Does the way you make a request change if the person you are addressing is your mother? What if you ask your teacher, or a classmate? What else influences the way you make a particular request? Think of some examples and write them down.

Now think about how you accomplish these things in English and how you do so in your native language. Are there any differences? Any similarities? Share your ideas with the class.

(Activity adapted from:

Wall, A. P. (1998). Say it naturally: Verbal strategies for authentic communication (level 1). 2ed. Boston, MA: Heinle \& Heinle.)

\section{Handout \# 5}

\section{Making Requests - Possible answers}

Each speaker wants the same result: the newspaper brought to him. Bob may not even realize he's making a direct command. It could simply be his style of speech: abrupt and direct. Or if Bob were in a position of authority, the command could be intentional. By adding the words would you as a tag question, Sam softens the command a little. He's obviously hoping his friend will reply, "Sure, no problem." Tom is using even more tact and politeness when he begins, "Would you mind...?” He is more considerate of the person's feelings, and the "Would you mind...?” is a very nonthreatening, pleasant way to begin a request. 


\section{Handout \# 6}

\section{Requesting}

To request something (to have, to borrow, or to use, for instance), you may use many polite forms. Most of them begin with auxiliaries. Here are a few common ways to make a request:

\begin{tabular}{|l|l|}
\hline$>$ May I have & $\begin{array}{l}\text { an apple? } \\
\text { a Coke? } \\
\text { another serving of rice, please? }\end{array}$ \\
\hline$>$ Could I borrow & $\begin{array}{l}\text { ten dollars? } \\
\text { your rake? } \\
\text { that book, please? }\end{array}$ \\
\hline$>$ Can I use & $\begin{array}{l}\text { that umbrella? } \\
\text { your hairdryer? } \\
\text { the phone if you don't mind? }\end{array}$ \\
\hline$>$ Would you mind if I & $\begin{array}{l}\text { had a sandwich? } \\
\text { borrowed your newspaper? } \\
\text { used your car this afternoon? }\end{array}$ \\
\hline
\end{tabular}

Practice: You want to borrow, have, or use the following items. Make a polite request, and try to use a different beginning for each one. Then come up with an example on your own.

Example: Your roommate’s iron

You: Charlie, may I borrow your iron for a few minutes?

1. Your co-worker's laptop

You:

2. The last piece of pie in the refrigerator

You:

3. Your classmate’s dictionary

You:

4.

You: 
To request some type of action, the following forms are often used, but there are many others, too.

\begin{tabular}{|l|l|}
\hline \multicolumn{1}{|l|}{$\begin{array}{l}\text { Could I trouble/bother } \\
\text { you to }\end{array}$} & $\begin{array}{l}\text { get me a cold drink? } \\
\text { help me with this? } \\
\text { answer the phone? }\end{array}$ \\
\hline$>$ Will you & $\begin{array}{l}\text { hand me that picture frame, please? } \\
\text { answer the phone while I'm out if you don't mind? } \\
\text { please clean your room before going outside? }\end{array}$ \\
\hline$>$ Would you mind & $\begin{array}{l}\text { not smoking at the table? } \\
\text { retyping this letter before you leave? } \\
\text { speaking more slowly, please? }\end{array}$ \\
\hline$>$ How/What about & $\begin{array}{l}\text { helping me with the dishes? } \\
\text { picking up some soft drinks on your way home? } \\
\text { turning your stereo down a little? }\end{array}$ \\
\hline
\end{tabular}

Practice: Request the following actions. Be polite and use a different beginning for each request. Then come up with an example on your own.

Example: You need help with cooking dinner. (Ask your roommate.)

You: How about some help with dinner, Paul? Could you make the salad, please?

1. You want your roommate to turn down the heat in the apartment.

You:

2. You want your neighbor to stop walking his dog across your freshly planted grass.

You:

3. You would like your friend to give you a ride to the airport tomorrow.

You:

4. You want your teacher to explain a grammar problem to you.

You:

5.

You:

(Activity adapted from:

Wall, A. P. (1998). Say it naturally: Verbal strategies for authentic communication (level 1). 2ed. Boston, MA: Heinle \& Heinle.) 


\section{Handout \# 7 - STUDENT A}

$\Rightarrow$ Requests:

Informal Requests: when you are speaking to friends, your family members, waiters, salespeople,

Formal Requests: when you are speaking to teachers, police, strangers, your boss, elderly people, important people,

$\Rightarrow$ Responses:

\section{Acceptance}

Sure.

I'd be glad to.

All right.

\section{$\underline{\text { Refusal with an excuse }}$}

I'm sorry, but I can't.

I'm sorry, but

I'd like to, but

STEP 1: Say your sentences to Student B. Then listen to Student B.

4. Tell your partner, “I'm a police officer.” Listen to your partner's request. Then refuse to help. Give an excuse.

5. Say, “I’m your boss.” Listen and refuse. Give an excuse.

6. Say, “I’m your friend.” Listen and agree.

\section{STEP 2: First listen to Student B. Then make your request.}

1. Ask your partner to tell you how much his car cost.

2. Ask your partner to tell you how much a particular shirt costs.

3. Ask your partner to tell you where the drugstore is.

(Activity adapted from: Kehe, D., \& Kehe, P. D. (2009). Conversation Strategies. Brattleboro, Vermont: Pro Lingua Associates.) 


\section{Handout \# 7 - STUDENT B}

$\Rightarrow$ Requests:

Informal Requests: when you are speaking to friends, your family members, waiters, salespeople,

Formal Requests: when you are speaking to teachers, police, strangers, your boss, elderly people, important people,

$\Rightarrow$ Responses:

\section{Acceptance}

Sure.

I'd be glad to.

All right.

\section{$\underline{\text { Refusal with an excuse }}$}

I'm sorry, but I can't.

I'm sorry, but

I'd like to, but

\section{STEP 1: First listen to Student A. Then make your request.}

1. Ask your partner to tell you where the nearest bus stop is.

2. Ask your partner to give you 3 days off from work. (You are tired and you need a rest.)

3. Ask your partner to lend you his/her cellphone. You need to call your mother.

\section{STEP 2: Say your sentences to Student A. Then listen to Student A.}

1. Say, “I'm your boss.” Listen and refuse. Give an excuse.

2. Say, “I’m a salesperson in a store.” Listen and agree.

3. Say, “I’m a middle-aged stranger.” Listen and refuse. Give an excuse.

(Activity adapted from: Kehe, D., \& Kehe, P. D. (2009). Conversation Strategies. Brattleboro, Vermont: Pro Lingua Associates.) 


\section{Handout \# 8}

\section{Situational Dialogue}

Here is a situation showing ways of making requests and responding to them. Read it and answer the questions or do the tasks required of you.

Michael, Juan, and Robert are in their senior year at an American university.

Michael: Hey, Juan, would you mind lending me your accounting book this evening? I left mine at school.

Juan: Sorry, Mike, but I've got to use mine tonight to study for my presentation tomorrow. Maybe you can borrow Robert's.

\section{What do you think?}

a. What does Michael need to borrow from Juan and why? Change Mike’s request slightly by using the word borrow.

b. What excuse does Juan offer by saying "no"? Does it seem valid (believable) to you? Why?

c. Change Juan's response to “yes” but add a condition (something that is necessary for his request to be granted) to his response. For example, "You can use my car if you put gas in it.” 


\section{EXPERIMENTAL GROUP - LESSON PLAN \#3}

\section{Goals:}

- To choose appropriate written requests to be used in e-mails to professors.

- To increase students' awareness of when apologies are necessary and what moves usually follow an apology in English.

- To give students practice apologizing and responding in English.

- To evaluate the appropriateness of responses based on contextual features.

\begin{tabular}{|c|c|c|c|}
\hline Objectives (Students will be able to...) & Materials & Procedures & Time \\
\hline $\begin{array}{l}\text { - choose appropriate e-mail requests for } \\
\text { feedback from professors on course } \\
\text { assignments. }\end{array}$ & $\begin{array}{l}\text { Handout \#9: } \\
\text { E-mail } \\
\text { Messages to } \\
\text { Professors }\end{array}$ & $\begin{array}{l}\text { Individual work } \\
\text { and whole-class } \\
\text { discussion. }\end{array}$ & Approx. 15min. \\
\hline $\begin{array}{l}\text { - discuss how apologies are made in } \\
\text { English and in students' native } \\
\text { languages. } \\
\text { explain the moves that are part of an } \\
\text { apology and give examples of situations } \\
\text { in which they are necessary and } \\
\text { situations in which they aren't. }\end{array}$ & $\begin{array}{l}\text { Handout \#10: } \\
\text { What would } \\
\text { you say to } \\
\text { another person } \\
\text { if... }\end{array}$ & $\begin{array}{l}\text { Individual, pair- } \\
\text { work, and } \\
\text { whole-class } \\
\text { discussion. }\end{array}$ & 25 min. \\
\hline $\begin{array}{l}\text { read three situations that involve the } \\
\text { speech acts of apology and request, } \\
\text { identify the speakers, the degree of } \\
\text { formality, the context, and the goal the } \\
\text { speaker wants to achieve. } \\
\text { decide what answer would be more } \\
\text { appropriate for each situation and } \\
\text { support their point of view with evidence } \\
\text { from the situation itself and from what } \\
\text { they have learned so far. }\end{array}$ & $\begin{array}{l}\text { Handout \# } \\
\text { 11: Situations }\end{array}$ & Group Work & 20 min. \\
\hline
\end{tabular}




\section{Handout \# 9}

\section{E-mail Messages to Professors}

Directions: You are submitting a piece of written work by e-mail to your academic professor for him/her to read and you want to ask him/her to provide feedback. Which of the requests below would you use in your e-mail? Which ones are appropriate? Which ones are inappropriate? Why do you think so?

\begin{tabular}{|c|c|c|c|c|}
\hline Request & Appropriate & Inappropriate & Not Sure & Reason \\
\hline \multicolumn{5}{|l|}{ Your thoughts on this? } \\
\hline \multicolumn{5}{|l|}{ I do need to get your feedback on this. } \\
\hline \multicolumn{5}{|l|}{$\begin{array}{l}\text { I'm looking forward to any feedback you } \\
\text { can provide. }\end{array}$} \\
\hline \multicolumn{5}{|l|}{$\begin{array}{l}\text { Please notify me, hopefully before the } \\
\text { weekend is over, on what I should do. }\end{array}$} \\
\hline \multicolumn{5}{|l|}{ I need your advice. } \\
\hline \multicolumn{5}{|l|}{ Please help me. } \\
\hline \multicolumn{5}{|l|}{$\begin{array}{l}\text { If possible, please review the draft and } \\
\text { reply me through e-mail tonight or early } \\
\text { next morning. }\end{array}$} \\
\hline \multicolumn{5}{|l|}{$\begin{array}{l}\text { I sent my research paper for you to put } \\
\text { your comments on last Friday. Up to } \\
\text { today, I do not receive any from you. }\end{array}$} \\
\hline $\begin{array}{l}\text { I want to know the results of final exam } \\
\text { so please let me know as soon as possible. }\end{array}$ & & & & \\
\hline
\end{tabular}

(Activity adapted from: http://exchanges.state.gov/englishteaching/resforteach/pragmatics.html - "What do you think? Requesting Responses from Professors. Donald L. Weasenforth) 


\section{Handout \# 9 - Answer Key}

\section{E-mail Messages to Professors}

Directions: You are submitting a piece of written work by e-mail to your academic professor for him/her to read and you want to ask him/her to provide feedback. Which of the requests below would you use in your e-mail? Which ones are appropriate? Which ones are inappropriate? Why do you think they are inappropriate?

General results from Weasenforth \& Biesenbach-Lucas (2000) are noted under each request.

\begin{tabular}{|l|l|l|l|l|}
\hline Request & Appropriate & Inappropriate & Not Sure & Reason \\
\hline $\begin{array}{l}\text { Your thoughts on this? } \\
\text { (Generally appropriate although a few } \\
\text { found it too casual) }\end{array}$ & & & \\
\hline $\begin{array}{l}\text { I do need to get your feedback on this. } \\
\text { (Inappropriate because of emphatic } \\
\text { "do") }\end{array}$ & & & \\
\hline $\begin{array}{l}\text { I'm looking forward to any feedback you } \\
\text { can provide. }\end{array}$ & & & \\
(Unquestionably appropriate) & & & \\
\hline $\begin{array}{l}\text { Please notify me, hopefully before the } \\
\text { weekend is over, on what I should do. } \\
\text { (Generally inappropriate due to deadline } \\
\text { imposition) }\end{array}$ & & & \\
\hline $\begin{array}{l}\text { I need your advice. } \\
\text { (Most found appropriate although use of } \\
\text { "need" raised questions) }\end{array}$ & & & & \\
\hline $\begin{array}{l}\text { Please help me. } \\
\text { (Most found appropriate although use of } \\
\text { "help” raised questions.) }\end{array}$ & & & & \\
\hline $\begin{array}{l}\text { If possible, please review the draft and } \\
\text { reply me through e-mail tonight or early } \\
\text { next morning. } \\
\text { (Inappropriate due to deadline } \\
\text { imposition) }\end{array}$ & & & & \\
\hline $\begin{array}{l}\text { I sent my research paper for you to put } \\
\text { your comments on last Friday. Up to } \\
\text { today, I do not receive any from you. } \\
\text { (Generally inappropriate due to deadline } \\
\text { imposition and apparent hostility) }\end{array}$ & & & & \\
\hline $\begin{array}{l}\text { I want to know the results of final exam } \\
\text { so please let me know as soon as possible. } \\
\text { (Generally inappropriate due to time } \\
\text { imposition) }\end{array}$ & & & & \\
\hline
\end{tabular}

(Activity adapted from: http://exchanges.state.gov/englishteaching/resforteach/pragmatics.html - "What do you think? Requesting Responses from Professors. Donald L.Weasenforth) 


\section{Handout \# 10}

\section{What would you say to another person if...}

- ... you accidentally stepped on the foot of the man sitting beside you at a concert?

- ... you turned in your homework a day late to your English professor?

- $\quad$... you were 20 minutes late to meet a friend for dinner?

Remember: An apology indicates that we realize we've made a mistake, and we're sorry for it. It's a way of expressing our regret or sorrow for something. When we apologize, we admit our wrongdoing or discourtesy (impolite action), usually offer a reason for it, and express regret.

Here are some commonly used expressions for beginning apologies. Can you think of other ways?

I beg your pardon, sir. (I didn’t realize you were speaking to me.) Formal

$>$ Pardon me, please, fore... (stepping on your foot.) Formal

$>$ I hope you'll forgive me... (my absence yesterday. I was ill.) Formal

$>$ Excuse me for... (being late. I forgot about the time.)

$>$ I apologize for... (knocking over your cup. I didn't see it.)

$>$ I'm very/really/awfully sorry... (that I woke you up.)

$>$ Sorry... (about the steak. I'll be glad to prepare you another one.)

$>$ Sorry about that. Informal

$>$

Practice: Look at each situation. Write a different reason or excuse that might fit the situation; offer to compensate the person for the problem; and/or make a promise to change, improve or not let the action happen again. All three steps (the excuse, the compensation, and the promise) may not always be necessary or appropriate. Be ready to defend your choices for including or omitting the steps in your apologies.

First, read an example of an apology: (Laura, to an acquaintance in English class) Margaret, I'm really sorry, but I lost the pen you let me borrow yesterday. I put it down on the seat beside me on the bus, and I guess I forgot to pick it up when I got off. Here. (She offers Margaret another pen.) I bought another one. I hope it's ok. and I'm really sorry. I'll be more careful next time.

e. You dropped and broke your friend's hairdryer.

You:

f. You borrowed and then forgot to return a classmate's dictionary.

You:

g. You backed your car into your neighbor's fence and broke the gate.

You:

h. You're 15 minutes late picking up a friend because you got a phone call as you were going out the door.

You: 
Here are some commonly used expressions for accepting apologies. Can you think of other ways?

That's quite all right. Formal

$>$ Think nothing of it. Formal

$>$ It's all right.

$>$ Don't worry about it.

$>$ No harm done.

$>$ That's okay.

$>$ Forget it. Informal

$>$ No problem. Informal

$>$ No big thing. Informal

$>$ It's cool. Very informal

Now sit with a partner and respond to each of the 4 apologies he/she gave in the previous exercise. Try performing an entire dialogue, and not just the apologies and responses. Then take turns.

(Activity adapted from:

Wall, A. P. (1998). Say it naturally: Verbal strategies for authentic communication (level 1). 2ed. Boston, MA: Heinle \& Heinle.) 


\section{Handout \# 11 Situations}

Directions: Imagine that the following situations take place in the United States. In groups discuss the situations below and for each of them , identify the speakers, the degree of formality, the context, and the goal the speaker wants to achieve. You need to not only choose the most appropriate answer, but also explain why the other two are not good for the situation described. If you think another answer would be more appropriate, feel free to write it down.

Situation: You are a student taking a speech class. Every day, several students give presentations. The professor has made a schedule and is very strict about keeping to the schedule. You are supposed to present tomorrow, but you have to go out of town at the same time class meets because of family obligations. Your father's best friend died and your father wants you to go to the funeral. What do you say to the professor about changing your presentation time?

a. I need to change my presentation day.

b. I appreciate your understanding in advance. You're such a good teacher. Do you think I can change my presentation day with no problems?

c. I'm really sorry about this, but I have to miss class tomorrow for a funeral. Is there any way I can reschedule?

Situation: As a part-time job, you are working as a library monitor. It is your job to make sure the library is quiet for all students who wish to study. While checking on each floor in the library, you see a group of students that you don't know talking loudly in non-discussion area. It seems clear that this loud noise disturbs other students' studying. You want those students to be quiet or move to a discussion area. You approach them. What would you say in order to make the students quiet?

a. This is a non-discussion area. Could you move to the first floor?

b. No talking here. You need to go downstairs if you continue talking.

c. Excuse me, I'm sorry to interrupt, but this part of the library is for quiet studying. If it's not too much trouble, could you please move to a discussion area?

Situation: You are applying for a job in a large company. You have just finished an interview with the manager. The interview went well but took much longer than you expected. You are getting ready to leave the office when the manager explains that it is time for a long tour of the company. You cannot go on the tour because you have another important meeting scheduled. So, what do you say?

a. Can I use your phone? (to change other appointment)

b. I'm sorry, but I have something else scheduled. Can I take the tour another time?

c. I'm sure I'll get a feel for it when I start working here. I don't need to have a tour.

Adapted from: Vellenga, H. E. (2008). Instructional effectiveness and interlanguage pragmatics. Dissertation Abstracts International, 69(06). (UMI No. 3318496) 


\section{LESSON PLAN \#4}

\section{Goals:}

- To discuss the influence of gender in linguistic forms, particularly when making a compliment.

- To raise students' awareness of the many ways one can refuse a suggestion.

- To give students more freedom to experience with language, practicing using role-plays.

- To act out different situations that include the five speech acts studied in the four lessons.

- To improve students' self-confidence in their ability to communicate.

\begin{tabular}{|l|l|l|l|}
\hline Objectives (Students will be able to...) & Materials & Procedures & Time \\
\hline $\begin{array}{l}\text { practice making and responding to } \\
\text { compliments in English. }\end{array}$ & $\begin{array}{l}\text { Handout \#12: } \\
\text { Complimenting } \\
\text { and } \\
\text { Responding }\end{array}$ & $\begin{array}{l}\text { Pair-work and } \\
\text { whole-class } \\
\text { discussion. }\end{array}$ & $\begin{array}{l}\text { Approx. } 25 \\
\text { min. }\end{array}$ \\
\hline $\begin{array}{l}\text { practice making and responding to } \\
\text { suggestions (accepting and } \\
\text { refusing). }\end{array}$ & $\begin{array}{l}\text { Handout \#13: } \\
\text { Making } \\
\text { suggestions }\end{array}$ & $\begin{array}{l}\text { Individual, } \\
\text { whole-class } \\
\text { discussion, } \\
\text { role-play. }\end{array}$ & 10 min. \\
\hline $\begin{array}{l}\text { act out different dialogues and } \\
\text { respond appropriately (review: } \\
\text { requests, apologies, compliments, } \\
\text { suggestions, refusals) }\end{array}$ & $\begin{array}{l}\text { Handout \# 14: } \\
\text { Situations }\end{array}$ & Role-play. & 25 min. \\
\hline
\end{tabular}




\section{Handout \# 12 Complimenting and Responding}

In pairs, discuss the following questions:

* What is easier: Complimenting people or responding to compliments? Why?

* Do you feel nervous or embarrassed when people pay you a compliment?

* Do you think that women pay more compliments than men?

* What do you usually compliment people on?

Here are some beginnings of responses to compliments. These may vary with the situation and the particular compliment. Try to think of others.

$>$ You're too kind. Formal (Compliment: The dinner was delicious.)

$>$ Thank you for saying so. (Compliment: You did a fine job on the report.)

> I appreciate the compliment. (Compliment: That's a beautiful belt!)

$>$ Thank you. I'm glad you like it. (Compliment: Your hair looks nice.)

$>$ Thank you. I'm glad you enjoyed it. (Compliment: The cake was wonderful.)

$>$ Thank you. I'm glad you think so. (Compliment: Your car drives great!)

$>$ Thanks, I like your too. (Return the compliment)

\section{Situational Dialogues}

The following dialogues show various situations where complimenting (as well as flattering and congratulating) and responding to the compliments take place. Listen to the tape; then choose partners, take roles, and act out a dialogue, using any gestures or facial expressions you feel are appropriate. Afterwards, analyze each dialogue.

\section{Yoko is standing at the bus stop, and Carol, an acquaintance, joins her.}

CAROL: Hi, Yoko. I almost didn’t recognize you with your hair fixed that way. It looks great! YOKO: Do you really like it? I wasn't too sure about it yesterday when I had it done. CAROL: It really looks nice. It flatters you - especially your eyes.

YOKO: Well, thanks. I was nervous about having it done, but I guess I'm glad I did. CAROL: I know what you mean. I'm always reluctant about changing anything about my appearance. But I'm serious - your hair really looks cute!

\section{Larry and Bashar are sitting in their dorm room, watching a tennis match on TV.}

BASHAR: By the way, Larry, I was walking by the tennis courts this afternoon and saw you and Hernando playing. Your serve was unbeatable!

LARRY: Thanks, Bashar. I don't know what happened, but I aced him five times!

BASHAR: Wow! And your backhand wasn't bad, either!

LARRY: Well, it still needs some work. I don't feel as comfortable with it as I do my forehand. You need to give me some pointers on that part of my game! Yours is incredible!

BASHAR: Aw - it's okay, but I don't think it's that good.

Do you think that each dialogue corresponds to the way men and women speak? What about a dialogue between a man and a woman? As a class, come up with a situation in which either one of them would compliment the other and write a dialogue. 


\section{Handout \# 13}

\section{Making Suggestions}

Read the following suggestions. Which ones are more formal? Can you think of other ways to make a suggestion?

Why don't you / we go to the movies tonight?

$>$ You / we could visit the Metropolitan Museum of Art while you're / we're there.

$>$ Let's go to the mall this afternoon to buy Anna's birthday gift.

$>$ What about asking your mother for help?

$>$ How about going to Florida for your vacation?

$>$ I suggest you / we take all the factors into consideration before we decide.

$>$

You can either accept or refuse a suggestion. Refusing is more problematic. Why?

Here are some ways you can refuse a suggestion:

$>$ That sounds wonderful, but...

$>$ I'd like / I'd love to, but...

$>$ Thanks, but...

$>$ I'm sorry, but...

$>$ Maybe some other time.

$>$ Perhaps next time.

$>$ I can't go, I already have other plans.

$>$ I can't make it, I have to...

$>$

Now walk around the room and make a suggestion to a classmate. Your classmate may choose to accept it or to refuse it. Talk to as many people as possible and take turns.

Adapted from: Wall, A. P. (1998). Say it naturally: Verbal strategies for authentic communication (level 2). 2ed. Orlando, FL: Harcourt Brace \& Company. 


\section{Handout \# 14 \\ Role-Plays (Review)}

Choose a partner and take roles to act out the following situations. They require requesting, apologizing, complimenting, suggesting, refusing, and responding appropriately. Take turns.

1. You would like you teacher to give you an extra day to finish a paper.

2. A friend asks you how you like her new purple lipstick and nail polish. You hate it, but you don't want to hurt her feelings.

3. You would like your roommate to turn the TV off so you can go to sleep.

4. You are supposed to go out with a friend for dinner together tonight, but you feel as if you are getting the flu.

5. You lost your temper yesterday and said some very angry words to your co-worker.

6. You would like your neighbor to give you a ride to work in the morning.

7. Your employer thinks you've done an excellent job on a difficult assignment.

8. You're driving your new car, and a friend compliments you on it.

9. You're having dinner at a friend's house, and he has fixed a delicious meal.

10. You have an important test coming up and you would like to get together with your classmates to study for it together.

Adapted from:

Wall, A. P. (1998). Say it naturally: Verbal strategies for authentic communication (level 1). 2ed. Boston, MA: Heinle \& Heinle.) Wall, A. P. (1998). Say it naturally: Verbal strategies for authentic communication (level 2). 2ed. Orlando, FL: Harcourt Brace \& Company. 


\section{LESSON PLAN \#1}

\section{Goals:}

- To give students more speaking practice.

- To learn how to paraphrase, rephrase.

- To address problem areas in pronunciation.

\begin{tabular}{|l|l|l|c|}
\hline Objectives (Students will be able to...) & Materials & Procedures & Time \\
\hline $\begin{array}{l}\text { discuss the importance of being able } \\
\text { to describe things / feelings / places, } \\
\text { etc. }\end{array}$ & $\begin{array}{l}\text { Handout \#1: } \\
\text { Finding the } \\
\text { Right Word I }\end{array}$ & $\begin{array}{l}\text { Individual, pair- } \\
\text { work, whole-class } \\
\text { discussion. }\end{array}$ & $\begin{array}{c}\text { Approx. } 20 \\
\text { min. }\end{array}$ \\
\hline $\begin{array}{l}\text { describe familiar words. } \\
\text { describe words and address problem } \\
\text { areas in pronunciation. }\end{array}$ & $\begin{array}{l}\text { Handout \#2: } \\
\text { Finding the } \\
\text { Right Word } \\
\text { II }\end{array}$ & $\begin{array}{l}\text { Group work. } \\
\text { Pair work. }\end{array}$ & 30 min. \\
\hline $\begin{array}{l}\text { address problem areas in } \\
\text { pronunciation. }\end{array}$ & --- & $\begin{array}{l}\text { Wrap-up. Teacher } \\
\text { invites students to } \\
\text { share their words } \\
\text { from exercise } 2 .\end{array}$ & 10 min. \\
\hline
\end{tabular}




\section{Handout \# 1}

\section{Finding the Right Word I}

1. Read the description and tell what it is.

A. This is something we read. Most people get one every day. In it, we can read about the news, sports, and entertainment. It also has some pictures. It's black and white, but it's read everywhere. What's it called?

B. This is something we use when it rains. We open it up and hold it over our heads. It keeps us dry. What do we call it?

2. Why is it important to be able to describe things, feelings, places, etc.?

3. In which situations would it be particularly important to be able to describe something? Discuss with a partner and make some notes.

(Possible Answers: When we don't know the right word to say; when we forgot the word in a language; when our interlocutor doesn't understand our pronunciation)

4. What clues can you give your interlocutor so he/she can either help you come up with the word and/or understand what you are trying to say? Discuss with a partner and make some notes.

(Possible Answers: Say: “The word I'm looking for is...”, "What do you/we call...?”, “What's it called?”, “It's used for...”, "You see it....”, “It looks/tastes/smells like...”) 


\section{Handout \# 2}

\section{Finding the Right Word II}

1. Group Work. Choose a word from the list below and describe it to your classmates and have them guess what it is. Take turns.

Example: Student A: The word I'm looking for are people in a family.

Student B: Is mother the word you are looking for?

Student A: Kind of. Mother and father together.

Student C: Do you mean parents?

\begin{tabular}{|c|c|c|c|}
\hline China & lawyer & car & accident \\
\hline spaghetti & passport & cloud & postcard \\
\hline shoe & alcohol & Mexico & embarrassed \\
\hline basketball & outgoing & holiday & wedding \\
\hline
\end{tabular}

2. Pair Work. Think of words that you find it difficult to pronounce. Don't tell your partner. Describe it to your partner and see if he/she can guess what it is. Afterwards, discuss the pronunciation of that word.

(Activity adapted from: Kehe, D., \& Kehe, P. D. (2009). Conversation Strategies. Brattleboro, Vermont: Pro Lingua Associates.) 
APPENDIX C: PARTICIPANT QUESTIONNAIRE

\section{PARTICIPANT QUESTIONNAIRE}

\section{Personal Information}

1. Full name:

2. Sex: $\square$ male $\square$ female

3. Birth year:

4. Nationality:

\section{School Information}

5. WVU e-mail address:

6. Personal e-mail address:

7. IEP Level: $\square$ Green $\square$ Blue A $\square$ Blue B $\square$ Gold A $\square$ Gold B

8. WVU ESL Class: $\square$ Graduate $\square$ Undergraduate

9. Highest degree received:

\section{Language Background}

10. Native language:

11. Do you speak any other languages? $\square \mathrm{Yes} \quad \square$ No If yes, which one(s)?

12. Have you studied any other languages? $\square$ Yes $\quad \square$ No If yes, which one(s)?

13. Overall, how long have you been studying English? (choose one)
a. 1-6 months
b. $6-12$ months
c. 1 -2 years
d. 2-3 years
e. Over 3 years

14. How long have you been studying in the IEP?

15. How long have you been in the United States?

16. Have you lived in a foreign country prior to coming to the U.S.? $\square$ Yes $\square$ No If yes, which one(s)?

For how long?

17. On average, how often do you interact with native speakers of English after class? (choose one)
a. Less than 1 hour a day.
b. 1-2 hours a day.
c. 2-3 hours a day.
d. More than 3 hours a day. 
Name:

\section{WVU - Department of World Languages, Literatures, and Linguistics LANGUAGE PROFICIENCY TEST}

Spring 2012
Date:

Score: /54

This language proficiency test is designed to measure your English ability. This test is divided into 3 Parts (Structure, Written Expression, and Reading Comprehension) and contains a total of 54 questions. Read the directions carefully. You will have 50 minutes to complete the test. 


\section{PART 1. Structure}

Directions: The following are nine sentences each with a blank in it. Beneath each sentence you will see four options, marked (A), (B), (C), and (D). Choose the one that best completes the sentence. Then, on your answer sheet, find the number of the question and circle the letter that corresponds to the answer you have chosen.

1. with the largest alphabet is Cambodian, with 74 letters.
(A) In the language
(B) The language is
(C) The language
(D) About the language

2. The planet Mercury rotations during every two trips around the sun.
(A) three complete
(B) completes three
(C) the completion of three
(D) completing three of the

3. The Rose Bowl, collegiate football game in the United States. place on New Year's Day, is the oldest postseason
(A) takes
(B) which takes
(C) it takes
(D) took

4. off the Hawaiian coastline are living, others are dead.
(A) Coral reefs
(B) Some types of coral reefs
(C) There are many types of coral reefs
(D) While some types of coral reefs

5. It is at the age of approximately eighteen months children begin to make combinations of two or three words.
(A) when many
(B) when are many
(C) when do many
(D) when have many of the 
6. One difference between mathematics and language is that mathematics is precise
(A) language is not
(B) while language is not
(C) but language not
(D) while is language

7. provided a living for nearly 90 percent of the population of the American colonies.
(A) Farming was what
(B) What farming
(C) Farming was
(D) What was farming

8. Not only withstand high winds. more brittle than hard maples, but they are also less able to
(A) soft maples are
(B) are soft maples
(C) they are soft maples
(D) soft maples

9. The surrealistic movement in art in the 1920s and 1930s placed in the unconscious and often incorporated dreamlike images.

is pictured
(A) to emphasize it
(B) an emphasis on it
(C) emphasize what
(D) an emphasis on what

\section{PART 2: Written Expression}

Directions: In these questions, each sentence has four underlined parts. The four underlined parts of the sentence are marked (A), (B), (C), and (D). Identify the one that must be changed in order for the sentence to be correct. Then, on your answer sheet, find the number of the question and circle the letter that corresponds to the answer you have chosen. 
10. The community of Bethesda, Maryland, was previous known as Darcy’s Store.
A
B
C D

11. By the time of the dinosaurs, turtles have already developed the hard shell into which their A $B$ heads and legs could be $\underline{\text { drawn. }}$.

$\mathrm{D}$

12. Sirius, the Dog Star, is the most brightest star in the sky with an absolute magnitude about A B twenty-three times that of the Sun.

C D

13. The remains of Homo erectus, an extinct species of early man, was first discovered on the A B

$\mathrm{C}$

$\mathrm{D}$

island of Java by Dutch physician Eugene Debois.

14. Lemon trees are similar in longevity and appear to orange trees but have more upright A $\quad$ B growth.

$\mathrm{D}$

15. Benny Goodman was equally talented as both a jazz performer as well as a classical

A $\quad$ B C musician.

$\mathrm{D}$

16. Thirty-one pairs of spinal nerves are present in humans, and each pair have two roots.
A
B C
$\mathrm{D}$

17. The electromagnetic spectrum consists in bands of different wavelengths.
A
B C
$\mathrm{D}$

18. Howard Hughes once did more than half a billion dollars in one day in 1966 when he A B received a single bank draft for $\$ 546,549,171$ for his share of TWA.

C

$\mathrm{D}$

19. By 1830, approximately 200 steamboats had become operationally on the Mississippi River.
A
B
$\mathrm{C}$
D 
20. The Ford Motor Company introduced the moving assembly line in 1914 so that it will be able A B to meet the huge demand for its Model T.
C
$\mathrm{D}$

21. The huge Meteor Crater was created when a 63,000-ton iron meteorites struck the Earth near A B C $\mathrm{D}$ Winslow, Arizona.

22. Christopher Columbus, alike many other explorers, underestimated the size of the Earth and A B C overestimated the width of Asia.

$\mathrm{D}$

23. Because of the mobility of Americans today, it is difficult for they to put down real roots.
A
B
C
$\mathrm{D}$

24. The closer it gets to December 21, the first day of winter, the short the days become.

A

B

C

D

\section{PART 3: Reading Comprehension}

Directions: In this part you will read 3 passages. Each one is followed by 10 questions about it. You are to choose the best one answer, (A), (B), (C), or (D), to each question. Then, on your answer sheet, find the number of the question and circle the letter that corresponds to the answer you have chosen. 


\section{Questions 25-34}

John James Audubon, nineteenth-century artist and naturalist, is known as one of the foremost authorities on North American birds. Born in Les Cayes, Haiti, in 1785, Audubon was raised in France and studied art under French artist Jacques-Louis David. After settling on his

Line

(5)

(10) father's Pennsylvania estate at the age of eighteen, he first began to study and paint birds.

In his young adulthood, Audubon undertook numerous enterprises, generally without a tremendous amount of success; at various times during his life he was involved in a mercantile business, a lumber and grist mill, a taxidermy business, and a school. His general mode of operating a business was to leave it either unattended or in the hands of a partner and take off on excursions through the wilds to paint the natural life that he saw. His business career came to an end in 1819 when he was jailed for debt and forced to file for bankruptcy.

It was at that time that Audubon began to seriously pursue the dream of publishing a collection of his painting of birds. For the next six years he painted birds in their natural habitats while his wife worked as a teacher to support the family. His Birds of America, which included engravings of 435 of his colorful and lifelike watercolors, was published in parts during the period from 1826 to 1838 in England. After the success of the English editions, American editions of his work were published in 1839, and his fame and fortune were ensured.
25. This passage is mainly about

(A) North-American birds

(B) Audubon's route to success as a painter of birds

(C) the works that Audubon published

(D) Audubon's preference for travel in natural habitats

26. The word "foremost" in line 2 is closest in meaning to

(A) prior

(B) leading

(C) first

(D) largest

27. According to the passage, Audubon

(A) studied birds while he lived in France.

(B) was born and raised in France.

(C) moved to the United States to study and paint birds.

(D) is an expert on North American Birds.

\section{In the second paragraph, the author mainly} discusses

(A) how Audubon developed his painting style

(B) Audubon's involvement in a mercantile business

(C) where Audubon went on his excursions

(D) Audubon's unsuccessful business practices
29. The word "mode" in line 7 could best be replaced by
(A) method
(B) vogue
(C) average
(D) trend

\section{Audubon decided not to continue to pursue business when \\ (A) he was injured in an accident at a grist mill \\ (B) he decided to study art in France \\ (C) he was put in prison because he owed money \\ (D) he made enough money from his paintings}

\section{The word "pursue" in line 11 is closest in} meaning to
(A) imagine
(B) share
(C) follow
(D) deny

32. According to the passage, Audubon's paintings

(A) were realistic portrayals

(B) used only black, white, and gray

(C) were done in oils

(D) depicted birds in cages 
33. The word "support" in line 13 could best be replaced by

(A) tolerate

(B) provide for

(C) side with

(D) fight for
34. It can be inferred from the passage that after 1839 Audubon

(A) unsuccessfully tried to develop new businesses

(B) continued to be supported by his wife

(C) traveled to Europe

(D) became wealthy

\section{Questions 35-44}

Niagara Falls, one of the most famous North American natural wonders, has long been a popular tourist destination. Tourists today flock to see the two falls that actually constitute Niagara Falls: the 173-foot-high Horseshoe Falls on the Canadian side of the Niagara River in the Canadian

Line province of Ontario and the 182-foot-high American Falls on the U.S. side of the river in the state of New York. Approximately 85 percent of the water that goes over the falls actually goes over Horseshoe Falls, with the rest going over American Falls.

Most visitors come between April and October, and it is quite a popular activity to take a steamer out onto the river and right up to the base of the falls for a close-up view. It is also possible to get a spectacular view of the falls from the strategic locations along the Niagara River, such as

(10) Prospect Point or Table Rock, or from one of the four observation towers which have heights up to 500 feet.

Tourists have been visiting Niagara Falls in large numbers since the 1800s; annual visitation now averages above 10 million visitors per year. Because of concern that all these tourists would inadvertently destroy the natural beauty of this scenic wonder, the state of New York in 1885 created Niagara Falls Park in order to protect the land surrounding American Falls. A year later Canada created Queen Victoria Park on the Canadian side of the Niagara, around Horseshoe Falls. With the area surrounding the falls under the jurisdiction of government agencies, appropriate steps could be taken to preserve the pristine beauty of the area.

35. What is the major point that the author is making in this passage?

(A) Niagara Falls can be viewed from either the American side or the Canadian side.

(B) A trip to the United States isn't complete without a visit to Niagara Falls.

(C) Niagara Falls has had an interesting history.

(D) It has been necessary to protect Niagara Falls from the many tourists who go there.

36. The word "flock" in line 2 could best be replaced by

(A) come by plane

(B) come in large numbers

(C) come out of boredom

(D) come without knowing what they will see

37. According to the passage, which of the following best describes Niagara Falls?

(A) Niagara Falls consists of two rivers, one Canadian and the other American.

(B) American Falls is considerably higher than Horseshoe Falls.

(C) The Niagara River has two falls, one in Canada and one in the United States.

(D) Although the Niagara River flows through the United States and Canada, the falls are only in the United States. 
38. A "steamer" in line 8 is probably
(A) a bus
(B) a boat
(C) a walkway
(D) a park

39. The expression "right up" in line 8 could be best replaced by
(A) turn to the right
(B) follow correct procedures
(C) travel upstream
(D) all the way up

40. The passage implies that tourists prefer to
(A) visit Niagara Falls during warmer weather
(B) see the falls from a great distance
(C) take a ride over the falls
(D) come to Niagara Falls for a winter vacation
41. According to the passage, why was Niagara Park created?
(A) To encourage tourists to visit Niagara Falls.
(B) To show off the natural beauty of Niagara Falls.
(C) To protect the area around Niagara Falls.
(D) To force Canada to open Queen Victoria Park.

42. The word “jurisdiction" in line 17 is closest in meaning to
(A) view
(B) assistance
(C) taxation
(D) control

43. The word "pristine" in line 18 is closest in meaning to
(A) pure and natural
(B) highly developed
(C) well-regulated
(D) overused

44. The paragraph following the passage most probably discusses
(A) additional ways to observe the falls
(B) steps taken by government agencies to protect the falls
(C) a detailed description of the division of the falls between the United States and Canada
(D) further problems that are destroying the area around the falls 


\section{Questions 45-54}

Esperanto is what is called a planned, or artificial, language. It was created more than a century ago by Polish eye doctor Ludwik Lazar Zamenhof. Zamenhof believed that a common language would help to alleviate some of the misunderstandings among cultures.

Line

(5)

In Zamenhof's first attempt at a universal language, he tried to create a language that was as uncomplicated as possible. This first language included words such as $a b, a c, b a, e b, b e$, and $c e$. This did not result in a workable language in that these monosyllabic words, though short, were not easy to understand or to retain.

Next, Zamenhof tried a different way of constructing a simplified language. He made the words in his language sound like words that people already knew, but he simplified the grammar tremendously. One example of how he simplified the language can be seen in the suffixes: all nouns in this language end in -o, as in the noun amiko, which means "friend," and all adjectives end in $-a$, as in the adjective bela, which means "pretty". Another example of the simplified language can be seen in the prefix mal-, which makes a word opposite in meaning; the word malamiko therefore means "enemy", and the word malbela therefore means "ugly” in Zamenhof's language.

In 1887, Zamenhof wrote a description of this language and published it. He used a pen name, Dr. Esperanto, when signing the book. He selected the name Esperanto because this word means “a person who hopes” in his language. Esperanto clubs began popping up throughout Europe, and by 1905, Esperanto had spread from Europe to America and Asia.

In 1905, the First World Congress of Esperanto took place in France, with approximately 700 attendees from 20 different countries. Congresses were held annually for nine years, and 4,000 attendees were registered for the Tenth World Esperanto Congress scheduled for 1914, when World War I erupted and forced its cancellation.

Esperanto had its ups and downs in the period since World War I. Today, years after it was introduced, it is estimated that perhaps a quarter of a million people are fluent in it. This may seem like a large number, but it is really quite small when compared with the billion English speakers and billion Mandarin Chinese speakers in today's world. Current advocates would like to see its use grow considerably and are taking steps to try to make this happen.

\section{The topic of this passage is}

(A) a language developed in the last few years

(B) one man's efforts to create a universal language

(C) how language can be improved

(D) using language to communicate internationally

46. According to the passage, Zamenhof wanted to create a universal language

(A) to resolve cultural differences

(B) to provide a more complex language

(C) to build a name for himself

(D) to create one world culture
47. It can be inferred from the passage that the Esperanto word malespera means

(A) hopelessness

(B) hope

(C) hopeless

(D) hopeful

48. The expression "popping up" in line 17 could be best replaced by
(A) leaping
(B) shouting
(C) hiding
(D) opening 
49. It can be inferred from the passage that the Third World Congress of Esperanto took place
(A) in 1905
(B) in 1907
(C) in 1909
(D) in 1913

50. According to the passage, what happened to the Tenth World Esperanto Congress?
(A) It had 4,000 attendees.
(B) It was scheduled for 1915.
(C) It had attendees from 20 countries.
(D) It never took place.

51. The expression "ups and downs" in line 23 is closest in meaning to
(A) tops and bottoms
(B) floors and ceilings
(C) takeoffs and landings
(D) highs and lows

52. Which paragraph describes the predecessor to Esperanto?
(A) The first paragraph
(B) The second paragraph
(C) The third paragraph
(D) The fourth paragraph

53. This passage would most likely be assigned reading in a course on
(A) European history
(B) English grammar
(C) world government
(D) applied linguistics

54. The paragraph following the passage most likely discusses
(A) how current supporters of Esperanto are encouraging its growth
(B) another of Zamenhof's accomplishments
(C) the disadvantages of using an artificial language
(D) attempts to reconvene the World Congress of Esperanto in the 1920s 


\section{LANGUAGE PROFICIENCY TEST - Answer Key}

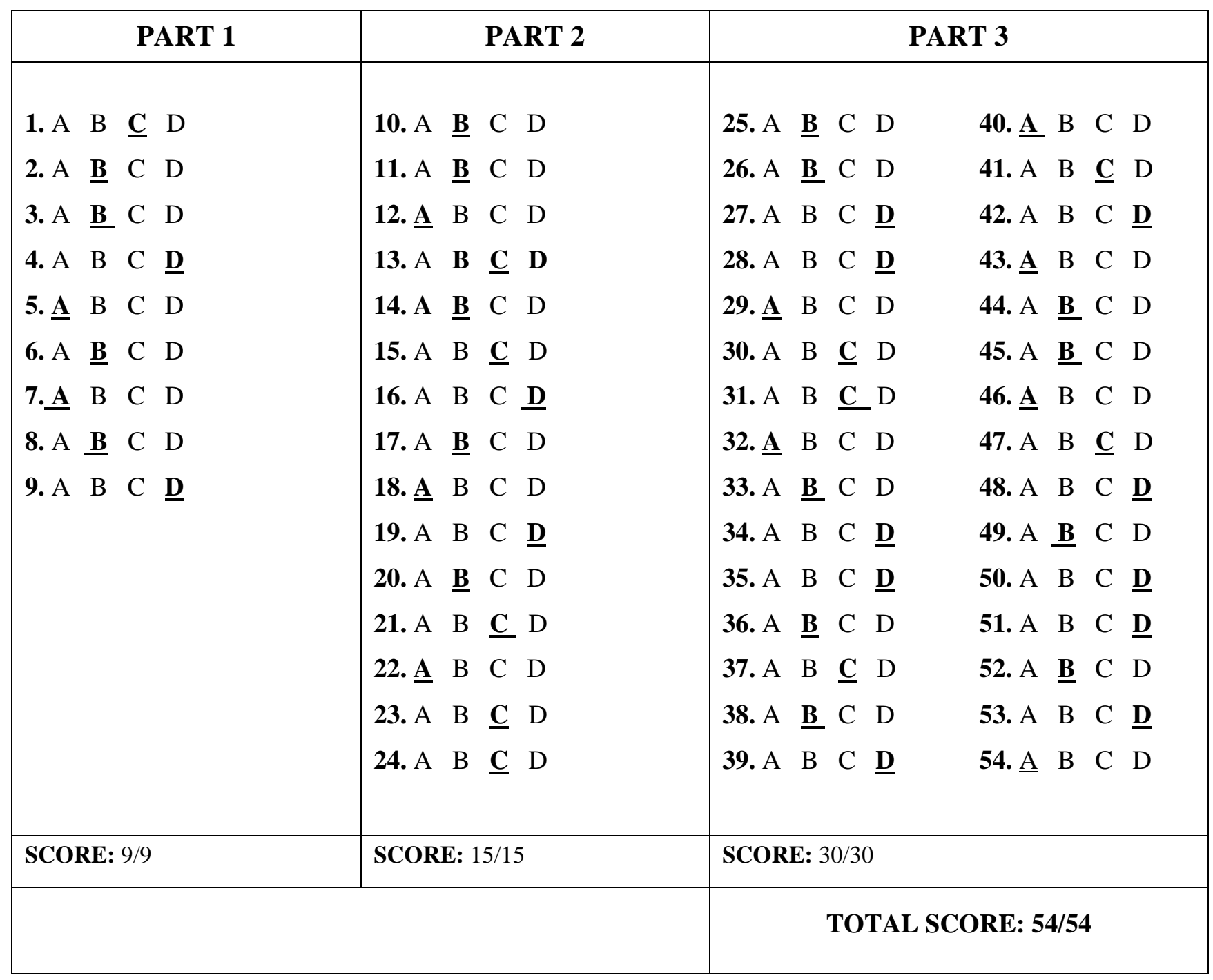


APPENDIX F: TABLE OF SPECIFICATIONS

Table of Specifications - Pragmatics Test Version 1

\begin{tabular}{|c|c|c|c|c|c|c|c|}
\hline \multirow{2}{*}{ Sections } & \multicolumn{5}{|c|}{ Main Speech Act } & $\begin{array}{c}\text { \# of } \\
\text { items of }\end{array}$ & $\begin{array}{c}\text { \% of } \\
\text { items }\end{array}$ \\
\cline { 2 - 8 } & Request & Refusal & Apology & Compliment & Suggestion & & \\
\hline $\begin{array}{c}\text { Part 1: } \\
\text { Discourse } \\
\text { Judgment } \\
\text { Task }\end{array}$ & 2 & 1 & 3 & -- & $4,5,6$ & 6 & 30 \\
\hline $\begin{array}{c}\text { Part 2: } \\
\text { MDCT }\end{array}$ & 7,11 & 8,10 & 12 & 9 & 13 & 7 & 35 \\
\hline $\begin{array}{c}\text { Part 3: } \\
\text { WDCT }\end{array}$ & $\begin{array}{c}14,16, \\
18\end{array}$ & 15,19 & 17,20 & -- & -- & 7 & 35 \\
\hline \# of items & 6 & 5 & 4 & 1 & 4 & 20 & \\
\hline \% of items & $30 \%$ & $25 \%$ & $20 \%$ & $5 \%$ & $20 \%$ & & 100 \\
\hline
\end{tabular}

Table of Specifications - Pragmatics Test Version 2

\begin{tabular}{|c|c|c|c|c|c|c|c|}
\hline \multirow{2}{*}{ Sections } & \multicolumn{5}{|c|}{ Main Speech Act } & $\begin{array}{c}\text { \# of } \\
\text { items }\end{array}$ & $\begin{array}{c}\% \text { of } \\
\text { items }\end{array}$ \\
\cline { 2 - 8 } & Request & Refusal & Apology & Compliment & Suggestion & & \\
\hline $\begin{array}{c}\text { Part 1: } \\
\text { Discourse } \\
\text { Judgment } \\
\text { Task }\end{array}$ & $2,5,6$ & 1 & 3 & -- & 4 & 6 & 30 \\
\hline $\begin{array}{c}\text { Part 2: } \\
\text { MDCT }\end{array}$ & 7,13 & 8,12 & 11 & 9 & 10 & 7 & 35 \\
\hline $\begin{array}{c}\text { Part 3: } \\
\text { WDCT }\end{array}$ & $\begin{array}{c}14,16, \\
18\end{array}$ & 15,19 & 17,20 & -- & -- & 7 & 35 \\
\hline \# of items & 8 & 5 & 4 & 1 & 2 & 20 & \\
\hline \% of items & $40 \%$ & $25 \%$ & $20 \%$ & $5 \%$ & $10 \%$ & & 100 \\
\hline
\end{tabular}

Table of Specifications - Pragmatics Test Version 3

\begin{tabular}{|c|c|c|c|c|c|c|c|}
\hline \multirow{2}{*}{ Sections } & \multicolumn{5}{|c|}{ Main Speech Act } & $\begin{array}{c}\text { \# of } \\
\text { items }\end{array}$ & $\begin{array}{c}\text { \% of } \\
\text { items }\end{array}$ \\
\cline { 2 - 8 } & Request & Refusal & Apology & Compliment & Suggestion & & \\
\hline $\begin{array}{c}\text { Part 1: } \\
\text { Discourse } \\
\text { Judgment } \\
\text { Task }\end{array}$ & 2,5 & 1 & 3 & -- & 4,6 & 6 & 30 \\
\hline $\begin{array}{c}\text { Part 2: } \\
\text { MDCT }\end{array}$ & 7,13 & $\begin{array}{c}8,10, \\
12\end{array}$ & -- & 9 & 11 & 7 & 35 \\
\hline $\begin{array}{c}\text { Part 3: } \\
\text { WDCT }\end{array}$ & $\begin{array}{c}14,16, \\
18\end{array}$ & 15,19 & 17,20 & -- & -- & 7 & 35 \\
\hline \# of items & 7 & 5 & 4 & 1 & 3 & 20 & \\
\hline \% of items & $35 \%$ & $25 \%$ & $20 \%$ & $5 \%$ & $15 \%$ & & 100 \\
\hline
\end{tabular}


APPENDIX G: PRAGMATICS TESTS

PRAGMATICS TEST VERSION 1

Name:

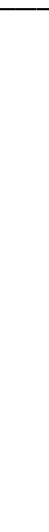

Date:

Score: $/ 20$

\section{WVU - Department of World Languages, Literatures, and Linguistics}

\section{Spring 2012}

This test is divided into 3 Parts and contains a total of 20 questions. There are multiple-choice items and items that will require you to write a response. Read the directions carefully. You will have 40 minutes to complete this test. 


\section{PART 1.}

Directions: Imagine that the following situations take place in the United States. All of them consist of conversations between Anna, Peter, George, their classmates, and their teachers. Their English will sometimes be appropriate but sometimes there will be a problem. Your job is to decide how well Anna and Peter use English in different conversations. When you finish reading each conversation, decide whether you think there is a problem or not and mark your answer sheet.

MODEL: Situation: Peter and Anna are classmates. They see each other in the hallway before classes start.

Peter: Good morning, Anna.

Anna: Good night, Peter.

Was Anna's response appropriate? $\square$ Yes $\square$ No

Anna's answer is obviously not good. So in the example on your answer sheet put an $X$ in the box marked NO.

- Situation 1: Peter and George are classmates. George invites Peter to his house, but Peter cannot come.

George: Peter, would you like to come over to my house tonight?

Peter: I'm sorry, I just can't. I'm very tired. I couldn't sleep last night.

2. Was Peter's response appropriate? $\quad \square$ Yes $\square$ No

- Situation 2: Peter and George are classmates. George is going to the library. Peter asks him to return a library book.

George: Well, I'll see you later. I've got to go to the library to return my books.

Peter: Oh, if you are going to the library, would you be so kind as to return my book too?

3. Was Peter's response appropriate? $\square$ Yes $\square$ No 
- Situation 3: Peter is going to George's house. He is quite late.

Peter: Hi George.

George: Hi Peter. I’ve been waiting for over half an hour for you. Weren't we supposed to meet at 4?

Peter: I couldn't come earlier. And anyway, we don't have to hurry anywhere.

4. Was Peter’s response appropriate? $\quad \square$ Yes $\square$ No

- Situation 4: Peter and Anna are classmates. They meet before class. They want to do something before class starts.

Anna: Hey, we've got 15 minutes before the next class. What shall we do?

Peter: Let's go to the snack bar.

5. Was Peter's response appropriate? $\quad \square$ Yes $\quad \square$ No

- Situation 5: Anna goes to see her teacher at his office. When she arrives, her teacher is busy.

Anna: (knocks on door)

Teacher: Yes, come in.

Anna: Hello, Mr. Gordon. Are you busy?

Teacher: Erm... I'm afraid so. Could you come back later?

Anna: Ok, I'll be here tomorrow morning at 8.

6. Was Anna’s response appropriate? $\quad \square$ Yes $\quad \square$ No

- Situation 6: Peter's teacher wants to talk to Peter about his exam. Peter makes arrangements to come back.

Teacher: Peter, we need to talk about your exam.

Peter: Yeah, if tomorrow is good, I could come any time you say.

7. Was Peter’s response appropriate? $\square$ Yes $\square$ No 


\section{PART 2.}

Directions: Imagine that the following situations take place in the United States. Read them and choose the most appropriate response. Then, on your answer sheet, find the number of the question and circle the letter that corresponds to the answer you have chosen.

8. Situation: You are a first-year student and have classes with many of the same people in every class. One day, you go to class and put the wrong folder in your bag. You don't have any paper to take notes on. Taking notes in this class is very important. What do you say to a classmate in order to get some paper?

d. Do me a favor? Give me some paper.

e. Do you have some extra paper I could borrow?

f. I wish I had some nice paper like yours.

9. Situation: You work as a travel agent. You are helping a customer at your desk. The customer gets out a packet of bubble-gum, takes one piece, and offers you a piece. You do not like bubblegum. So, what do you say?
a. No, thanks.
b. I'm very sorry, I just had a lot of dental work done and I shouldn't chew gum.
c. Thank you very much. That's so nice of you.

10. Situation: You're visiting an American friend in her new apartment. You like the apartment and you want your friend to know. What would you do?

a. Say, 'Your apartment is nice. How much is the rent?'

b. Say, 'I really like your apartment.'

c. Say nothing, but show that you are interested by walking around, looking at everything in the apartment, and picking up everything that is movable.

11. Situation: You are a student. A friend of yours has invited you for dinner several times, but cancels just before you're supposed to meet every time. You have decided not to accept any more invitations from this friend. While you are studying in the library, this friend invites you to dinner for that evening. What do you say?
a. No, I can't tonight. I have other plans.
b. Yeah, that sounds great.
c. You didn't keep your promise before, so I'm not going to accept your invitation.

12. Situation: You work as a waiter. You have worked at the same restaurant for two years. You are supposed to work this afternoon from 12 to 5, but you haven't been feeling well lately and you want to go and see your doctor. At 10:00am, you decide to call and ask your manager if you can have the afternoon off. What would you probably say in order not to work this afternoon?

a. Can I have the afternoon off? I need to see the doctor. 
b. I don't feel well today, so I think I should see my doctor. I have asked someone to cover my shift today... I hope you don't mind... I will work for them later.

c. I’ve been sick for a while now and I'm going to the doctor this afternoon. I won't work today.

13. Situation: You borrowed a book from your friend, Kate. You promised to return it today. She needs it for her presentation in class tomorrow. However, you left the book at home. You meet her in class and she says: "By the way, did you bring my book? I really need it for my presentation tomorrow." What would you say to her?

a. I'm sorry, but I don't have it with me right now.

b. I'm really sorry, but I left it at my apartment. Is there any way I can give it to you after class?

c. I'm sorry. But why didn't you call me before to remind me?

14. Situation: You have just passed the TOEFL exam and are ready to go to university. Before you register for your classes you make an appointment with your advisor to talk about the classes you will take in your first semester. When your advisor says “Ok, let’s talk about next semester”, what do you say?

a. I will take math.

b. I have no idea of which classes I can take next semester.

c. I was thinking of taking math.

\section{PART 3:}

Directions: In this part you will find short dialogues. Read the situations and think of what you would say in each situation. Then, write down the last line of the dialogue on your answer sheet.

\section{MODEL:}

\section{Scenario: QUESTIONNAIRE}

You go to ask your teacher to fill in a questionnaire. You knock on the office door.

You: (knock on the door)

Teacher: Yes, come in.

You: I'm sorry, Dr. Smith, but I was wondering if you had time to fill in this questionnaire for me. 
15. Scenario: QUIZ

You missed a quiz and would like to see if you could take it another time. You go to your teacher's office.

You: (knock on the door)

Teacher: Yes, come in.

You: Hello, Mr. Shumway,

\section{Scenario: CLASS TRIP}

The teacher asks you to help with the plans for the class trip, but you can't do it tonight.

Teacher: Ok, so we'll go by bus. Who lives near the bus station? Could you check the bus times for us on the way home tonight?

You:

17. Scenario: SNACK BAR

You go to the snack bar to get something to eat before class.

Server: May I help you?

You:

18. Scenario: NOT READY

It is your day to give your talk in class, but you are not ready.

Teacher: Thank you Steven, that was very interesting. Now it's your turn to give your talk. You:

19. Scenario: DIRECTIONS

You need directions to the library. You ask another student.

You: Hi.

Student: Hi.

You:

20. Scenario: INVITATION

You and Maria are friends. Maria invites you to her house but you cannot come.

Maria: Would you like to come over this afternoon?

You:

21. Scenario: MEETING

You forgot a meeting with a friend; this is the second time that the same thing has happened with the same person. At the end of the day your friend phones you.

Friend: I waited for you for more than twenty minutes! What happened?

You: 


\section{PRAGMATICS TEST VERSION 2}

Name:

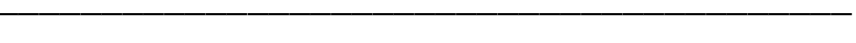

Date:______

SCORE:

120

\section{WVU - Department of World Languages, Literatures, and Linguistics}

Spring 2012

This test is divided into 3 Parts and contains a total of 20 questions. There are multiple-choice

items and items that will require you to write a response. Read the directions carefully. You will have 40 minutes to complete this test. 


\section{PART 1.}

Directions: Imagine that the following situations take place in the United States. All of them consist of conversations between Mary, John, Wesley, their classmates, and their teachers. Their English will sometimes be appropriate but sometimes there will be a problem. Your job is to decide how well Mary and John use English in different conversations. When you finish reading each conversation, decide whether you think there is a problem or not and mark your answer sheet.

MODEL: Situation: John and Mary are classmates. They see each other in the hallway before classes start.

John: Good morning, Mary.

Mary: Good night, John.

Was Mary’s response appropriate? $\square$ Yes $\square$ No

Mary's answer is obviously not good. So in the example on your answer sheet put an $X$ in the box marked NO.

- Situation 1: Wesley and John are classmates. Wesley invites John to play tennis, but John cannot come.

Wesley: John, what about a game of tennis after lunch?

John: I wish I could, Wesley, but I promised Nora I'd go with her to a movie this afternoon.

1. Was John’s response appropriate? $\square$ Yes $\square$ No

- Situation 2: Wesley and Mary are classmates. Wesley forgot his dictionary at home and would like to use Mary's.

Wesley: Would you mind if I borrowed your dictionary for an hour or so?

Mary: Of course, it's no problem at all.

2. Was Mary’s response appropriate? $\square$ Yes $\square$ No 
- Situation 3: Mary has an appointment with her teacher at 2 p.m. but she arrives only at 2:30.

Mary: (knocks on the door). Hello Mrs. Smith, may I come in?

Teacher: Yes, come in.

Mary: I know I'm late. Sorry about that.

3. Was Mary's response appropriate? $\quad \square$ Yes $\quad \square$ No

- Situation 4: Wesley and Mary are classmates. They run into each other right before class starts and Mary wants to invite Wesley to a concert.

Mary: Hey, Wesley!

Wesley: Hi, Mary!

Mary: Are you busy next Saturday night? There's a concert in the park that would be fun to go to.

4. Was Mary’s response appropriate? $\square$ Yes $\square$ No

- Situation 5: John meets his teacher during her lunch break and he is worried about his grade.

John: I would like to talk to you about my grade.

Teacher: Oh, I'm just on my lunch break.

John: Yes, but I really need to talk to you about my grade in your class.

5. Was John’s response appropriate? $\quad \square$ Yes $\quad \square$ No

- Situation 6: John is talking to his teacher. The conversation is almost finished.

Teacher: Well, I think that's all I can help you with at the moment.

John: That's great. Thank you so much for all the information.

6. Was John's response appropriate? $\quad \square$ Yes $\square$ No 


\section{PART 2.}

Directions: Imagine that the following situations take place in the United States. Read them and choose the most appropriate response. Then, on your answer sheet, find the number of the question and circle the letter that corresponds to the answer you have chosen.

7. Situation: You are a student working on a group project. You have a big project due in three days, but you haven't started on your part of the project. You don't understand exactly what you're supposed to do, and you want to ask another member of your group for help. You know this person is a very good student who is always prepared and finishes his assignments long before they are due. What do you say in order to get this student to help you?

a. Bob, I'm sure you're already done with the assignment, but I had a few questions about my section. Do you have time to meet later today?

b. I need your help with our project. We won't do well unless you help me.

c. Can you help me later today?

8. Situation: You are a university student. Another student who studies the same major you do sits next to you before class begins. You do not know this student well. This student invites you to go out to dinner for your birthday, and tells you there is a present for you. You already have plans for your birthday with your close friends, and prefer not to go. What do you say?

a. Sure, that sounds great.

b. I'm sorry I already have plans with my friends. Would you like to join us?

c. No, I don't want to.

9. Situation: Your co-worker just got a new ring and she's showing it around the office. You really liked it and you would wish to pay a compliment on the ring. What would you say?

a. Say, 'Nice ring!!! How much did it cost?'

b. Say, 'Where did you buy it? I'd like to get one for myself.'

c. Say, 'I really like your ring. It looks good on you.'

10. Situation: Your best friend would like to contact people from other countries in order to know other customs and be able to practice the English language. You think that using IRC (Internet relay chat) is a very good and fast way of meeting people from all over the world. What would you say to your friend?

a. Why don't you try using Internet relay chat?

b. Personally, I would recommend that you try using Internet relay chat.

c. It would be helpful if you used Internet relay chat.

11. Situation: You are a graduate student and didn’t type the paper you were supposed to turn in today. You go talk to your professor and apologize for not typing it. What would you say?

a. Sorry about that, but my paper isn't typed. 
b. I apologize for not typing my paper.

c. I hope you'll forgive me for not typing my paper, Dr. Williams. My laptop isn’t working and all the computer labs were full yesterday.

12. Situation: You just moved in a new neighborhood. Your neighbor sees you on the street and invites you over for a welcome dinner on Friday evening. You'd like to go and meet your new neighbors, but you're afraid you won't be able to make it because you might be working late that day. What would you say?
a. Sure. That would be wonderful.
b. I'm awfully sorry, but I can't come.
c. I may be busy that day. Could I let you know later this week?

13. Situation: You work as a Research Assistant and you haven't finished a report that was due this afternoon. What would you say to your professor?
a. I'm sorry, but I don't have it with me right now.
b. I apologize for not finishing the report. I forgot about the deadline.
c. I apologize, Ms. Lowery, but I'm running a little behind schedule. May I bring you the report tomorrow instead of this afternoon?

\section{PART 3:}

Directions: In this part you will find short dialogues. Read the situations and think of what you would say in each situation. Then, write down the last line of the dialogue on your answer sheet.

\section{MODEL:}

\section{Scenario: QUESTIONNAIRE}

You go to ask your teacher to fill in a questionnaire. You knock on the office door.

You: (knock on the door)

Teacher: Yes, come in.

You: I'm sorry, Dr. Smith, but I was wondering if you had time to fill in this questionnaire for me. 


\section{Scenario: HOMEWORK}

You didn't turn in your homework assignment on the day it was due because you missed that class. You would like to see if you could still hand it in. You go to your teacher's office.

You: (knock on the door)

Teacher: Yes, come in.

You: Hello, Mrs. Smith,

\section{Scenario: GRADING TESTS}

You are a Graduate Assistant and you work for a college professor. He asks you to grade a lot of tests by tonight, but you can't do it.

Professor: Ok, so I'm going to need you to have those tests graded by this evening.

You:

16. Scenario: CLOTHING STORE

You go to the clothing store after work and you have to be home soon.

Salesperson: May I help you?

You:

\section{Scenario: IN-LAWS COMING OVER}

Your in-laws are coming for dinner and they're expecting their favorite meal but you didn't find all the ingredients. You call them to say that you can’t have their favorite meal tonight.

Mother-in-law: Oh, I can’t wait to try my favorite meal that you're cooking!

You:

18. Scenario: DIRECTIONS

You need directions to the nearest mall. You ask a police officer.

You: Excuse me, officer.

Police Officer: Yes, how can I help you?

You:

19. Scenario: INVITATION

You and Tim are co-workers. Tim invites you out to lunch but you cannot come.

Tim: Do you want to grab lunch with me?

You:

20. Scenario: CANCELED DINNER PARTY

You forgot to call a friend to tell her that the dinner party was canceled and she has spent the whole day cooking something for it. You receive a phone call from her after the time that you were supposed to pick her up for the party.

Friend: Hey, where are you? Are you on your way?

You: 


\section{PRAGMATICS TEST VERSION 3}

NAME:

\section{NAME:}

DATE: $\angle / L / L$
SCORE: $\_/ 20$

WVU - Department of World Languages, Literatures, and Linguistics

Spring 2012

This test is divided into 3 Parts and contains a total of 20 questions. There are multiple-choice items and items that will require you to write a response. Read the directions carefully. You will have 40 minutes to complete this test. 


\section{PART 1.}

Directions: Imagine that the following situations take place in the United States. All of them consist of conversations between Ryan, Emily, Mike, their classmates, and their teachers. Their English will sometimes be appropriate but sometimes there will be a problem. Your job is to decide how well Ryan and Emily use English in different conversations. When you finish reading each conversation, decide whether you think there is a problem or not and mark your answer sheet.

MODEL: Situation: Ryan and Emily are classmates. They see each other in the hallway before classes start.

Ryan: Good morning, Emily.

Emily: Good night, Ryan.

Was Emily's response appropriate? $\square$ Yes $\square$ No

Emily's answer is obviously not good. So in the example on your answer sheet put an $X$ in the box marked NO.

- Situation 1: Ryan and Emily are classmates. Emily invites Ryan to a surprise party, but Ryan cannot come.

Emily: Ryan, I'm having a surprise party for Mary on Saturday. Can you make it?

Ryan: No, I can't.

1. Was Ryan’s response appropriate? $\quad \square$ Yes $\square$ No

- Situation 2: Ryan and Mike are classmates. Mike is having problems with his grammar exercise and asks Ryan for help.

Mike: Ryan, can you help me with this grammar exercise, please?

Ryan: Yes, I'm more than willing to help you out with that exercise.

2. Was Ryan’s response appropriate? $\square$ Yes $\square$ No 
- Situation 3: Emily and Mike are classmates. Mike borrowed Emily’s book a while ago and forgot to return it.

Mike: I'm sorry. I didn't mean to keep your book so long.

Emily: No big thing. I won't need it until next semester.

3. Was Emily’s response appropriate? $\quad \square$ Yes $\square$ No

- Situation 4: Mike and Ryan are classmates. They meet before class. They want to do something after class.

Mike: Hey, are you free after class?

Ryan: Sure, what did you have in mind?

4. Was Ryan’s response appropriate? $\quad \square$ Yes $\quad \square$ No

- Situation 5: Ryan goes to see his teacher at his office because he doesn’t understand why he got an F.

Ryan: Hello, Mr. Pearson. May I talk to you?

Teacher: Yes, what can I do for you?

Ryan: In class today you told me that my final grade would be an $\mathrm{F}$ for the course. I do not understand what that means.

Teacher: It means that you have not successfully completed the class. It means that you have not done the work required of you.

Ryan: But did I fail? I showed up for every class! I will lose my scholarship if I don't get an A in this course!

5. Was Ryan’s response appropriate? $\quad \square$ Yes $\quad \square$ No

- Situation 6: Emily's teacher wants to talk to Emily about her writing assignment. Emily makes arrangements to come back.

Teacher: Emily, we need to talk about your writing assignment.

Emily: Ok, I'll be here tomorrow at 2 p.m.

6. Was Emily’s response appropriate? $\quad \square$ Yes $\quad \square$ No 


\section{PART 2.}

Directions: Imagine that the following situations take place in the United States. Read them and choose the most appropriate response. Then, on your answer sheet, find the number of the question and circle the letter that corresponds to the answer you have chosen.

7. Situation: Tomorrow is the due date of a final term paper for one of the courses you are taking this semester. However, you are not able to turn it in on time because you caught a cold and had unexpected visitors from out of town staying with you. You want to talk to the professor, whom you have known for a couple of years, and ask for an extension on the paper. You go to the office and knock on the door. What would you say in order to get an extension?

a. I'm asking about an extension on the paper, since I won't be able to turn it in on time.

b. I'm sorry to bother you, but do you think it would be possible to have an extension on the final paper? I've been sick and had some people visit unexpectedly. I'd really appreciate it.

c. If you give me an extension on the final paper, I'll never forget your kindness.

8. Situation: You are a graduate student in a university program and there is another student in some of your classes. You have met with this student outside of class a couple of times, and know the student pretty well. Sometimes you have coffee together at the student union coffee shop. You see this student outside your building, and the student asks to borrow a book from you. You need to use the book this afternoon because you have a big test tomorrow. So, what would you say?

a. I would give it to you, but I need it this afternoon to study for a test.

b. Sure, here you are.

c. I want to lend you this book, but I will use it this afternoon for my test. How about tomorrow morning? Is that ok for you?

9. Situation: You're proofreading your classmate's paper and you find it very interesting. You can see that she has put a lot of effort into writing the paper, but there are still quite a few mistakes. What would you say?

a. I like your paper!

b. You did a good job on this, but here are some things that I would maybe change.

c. Your paper has a lot of mistakes, you need to fix them.

10. Situation: You are an exchange student at a university in the United States. The university president invites you for dinner and takes you to a restaurant that serves a dish made with special natural mushrooms. You do not like mushrooms, and would prefer to have something else. What do you say?

a. This looks delicious. Thanks for the invitation.

b. I'm sorry, but I'm allergic to mushrooms. Is there anything else served here?

c. I won't eat mushrooms. Order something else for me. 
11. Situation: You are talking to one of your best friends who is studying Computer Science Engineering. Both of you are talking about your plans for the next semester, and your friend says that he's thinking of taking Computer Architecture. He will also start his internship next month. You think this subject is very difficult and that he shouldn't take it next semester. What would you say to him?

a. Don't take Computer Architecture - that's a very hard class.

b. That's a lot of work. Why don't you wait until next year for that subject?

c. I personally recommend that you take another class if you are starting your internship.

12. Situation: You live in a small apartment complex and know your neighbors fairly well. You sometimes talk on the porch, and when you're away, your neighbor takes in your mail and waters your plants. You are reading the paper in the living room when your neighbor comes up and says, "I'll be away for most of next week. Do you think you could water my plants once or twice?" You cannot water the plants because you are going out of town. So, what would you say?

a. Sure, I'd be happy to.

b. Sorry, I'm going out of town, too. I was going to ask you the same thing.

c. No, I can't do it.

13. Situation: You are a recent college graduate who is applying for a job at a large corporation. The company has called you for a first interview, and at the end of the first interview, they ask for a second interview. You are very interested in a second interview, but you are very busy at your part-time job and can only come to interviews very early in the morning. The interviewer only wants to make afternoon appointments. What do you say in order to get an early morning interview?

a. I can only interview in the morning because of my other job.

b. I hate to ask this, but can you be more flexible?

c. I'm sorry to be so much trouble, but is there any possible way we could schedule the second interview in the morning?

\section{PART 3:}

Directions: In this part you will find short dialogues. Read the situations and think of what you

would say in each situation. Then, write down the last line of the dialogue on your answer sheet.

\section{MODEL:}

\section{Scenario: QUESTIONNAIRE}

You go to ask your teacher to fill in a questionnaire. You knock on the office door.

You: (knock on the door)

Teacher: Yes, come in.

You: I'm sorry, Dr. Smith, but I was wondering if you had time to fill in this questionnaire for me. 
14. Scenario: LECTURE EXPLANATION

Your professor was giving a very complicated lecture and you didn't do the reading beforehand so you had a hard time understanding it. You go up to him after class to ask for clarification on key points.

You: (knock on your professor’s office door)

Teacher: Yes, come in.

You: Hello, Mr. West,

\section{Scenario: WORK}

Your boss asks you to come in to work on your day off but you had already made other plans.

Boss: I can count on you to come in and help me do this, right?

You:

16. Scenario: COFFEE SHOP

You go to the coffee shop to get your favorite drink but you are in a very big hurry and the clerk Emily is moving very slowly.

Emily: May I help you?

You:

17. Scenario: MISSING HANDOUT

You are a student giving a presentation in front of your classmates. Everything is going well and you realize that you forgot a very important handout you were going to give to everyone.

Teacher: Is there a handout that goes along with this?

You:

18. Scenario: INFORMATION

You have a job interview and you can't find the location of the room. You stop and ask a secretary who works there.

You: Excuse me.

Secretary: Yes, may I help you?

You:

19. Scenario: INVITATION

Your neighbor invites you to his house to watch a football game but you hate football.

Michael: Hey, do you want to come over and watch the football game with me and my family tonight? You:

20. Scenario: LATE ASSIGNMENT

You have turned in a project for your class late for the second time. Your teacher had already given you one chance of forgiveness and you need to explain to him why you deserve another chance.

Teacher: I'm not going to accept this assignment because I've already given you a chance. You: 
APPENDIX H: PRAGMATICS TESTS ANSWER KEY

VERSION 1 - Answer Key

\begin{tabular}{|c|c|c|}
\hline & PART 1 & PART 2 \\
\hline $\begin{array}{l}\text { 1. } \square \text { Yes } \\
\text { 2. } \square \text { Yes } \\
\text { 3. } \square \text { Yes } \\
\text { 4. } \square \text { Yes } \\
\text { 5. } \square \text { Yes } \\
\text { 6. } \square \text { Yes }\end{array}$ & $\begin{array}{l}\square \text { No } \\
\square \text { No } \\
\square \text { No } \\
\square \text { No } \\
\square \text { No } \\
\square \text { No }\end{array}$ & 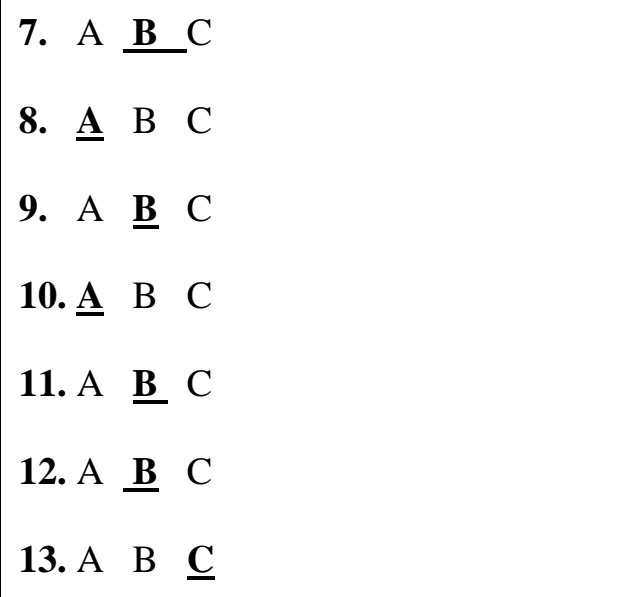 \\
\hline \multicolumn{3}{|c|}{ PART 3} \\
\hline \multicolumn{3}{|l|}{14.} \\
\hline \multicolumn{3}{|l|}{15.} \\
\hline \multicolumn{3}{|l|}{16.} \\
\hline \multicolumn{3}{|l|}{17.} \\
\hline \\
\hline \multicolumn{3}{|l|}{19.} \\
\hline \multicolumn{3}{|l|}{20.} \\
\hline & & TOTAL SCORE: 20/20 \\
\hline
\end{tabular}




\section{PART 3:}

14. Scenario: QUIZ

You missed a quiz and would like to see if you could take it another time. You go to your teacher's office.

You: (knock on the door)

Teacher: Yes, come in.

OPTION 1: You: Hello, Mr. Shumway, I am really sorry about missing the quiz. Is there any way I can make it up?

OPTION 2: You: Hello, Mr. Shumway, I'm sorry to disturb you, but I was wondering if I could make up the quiz I missed.

15. Scenario: CLASS TRIP

The teacher asks you to help with the plans for the class trip, but you can't do it tonight.

Teacher: Ok, so we'll go by bus. Who lives near the bus station? Could you check the bus times for us on the way home tonight?

OPTION 1: You: Unfortunately, I can’t tonight, but maybe I know someone who can. Let me check my phone book.

OPTION 2: You: I would love to, but I won't be able to do it tonight because I have other plans.

16. Scenario: SNACK BAR

You go to the snack bar to get something to eat before class.

Server: May I help you?

OPTION 1: You: Can I get ......, please?

OPTION 2: You: Yes, may I have an apple please.

\section{Scenario: NOT READY}

It is your day to give your talk in class, but you are not ready.

Teacher: Thank you Steven, that was very interesting. Now it's your turn to give your talk.

OPTION 1: You: I have to confess I am not fully prepared, would you still prefer me to go now, or can I make it up?

OPTION 2: You: Professor, would it be possible to do mine some other time? I'm not quite prepared like I would like.

18. Scenario: DIRECTIONS

You need directions to the library. You ask another student.

You: Hi.

Student: Hi.

OPTION 1: You: Do you know how to get to the library?

OPTION 2: You: Do you know where the library is by any chance?

\section{Scenario: INVITATION}

You and Maria are friends. Maria invites you to her house but you cannot come.

Maria: Would you like to come over this afternoon?

OPTION 1: You: Oh, I'd love to but I have to .... Raincheck?

OPTION 2: You: I'd love to but I'm busy tonight. 
20. Scenario: MEETING

You forgot a meeting with a friend; this is the second time that the same thing has happened with the same person. At the end of the day your friend phones you.

Friend: I waited for you for more than twenty minutes! What happened?

OPTION 1: You: Oh my God (friend), I am so sorry. Let me make it up to you, let's (something they love).

OPTION 2: You: Oh man, I'm really sorry. Can we meet ASAP? 
VERSION 2 - Answer Key

\begin{tabular}{|c|c|c|}
\hline & PART 1 & PART 2 \\
\hline $\begin{array}{l}\text { 1. } \square \text { Yes } \\
\text { 2. } \square \text { Yes } \\
\text { 3. } \square \text { Yes } \\
\text { 4. } \square \text { Yes } \\
\text { 5. } \square \text { Yes } \\
\text { 6. } \square \text { Yes }\end{array}$ & $\begin{array}{l}\square \text { No } \\
\square \text { No } \\
\square \text { No } \\
\square \text { No } \\
\square \text { No } \\
\square \text { No }\end{array}$ & 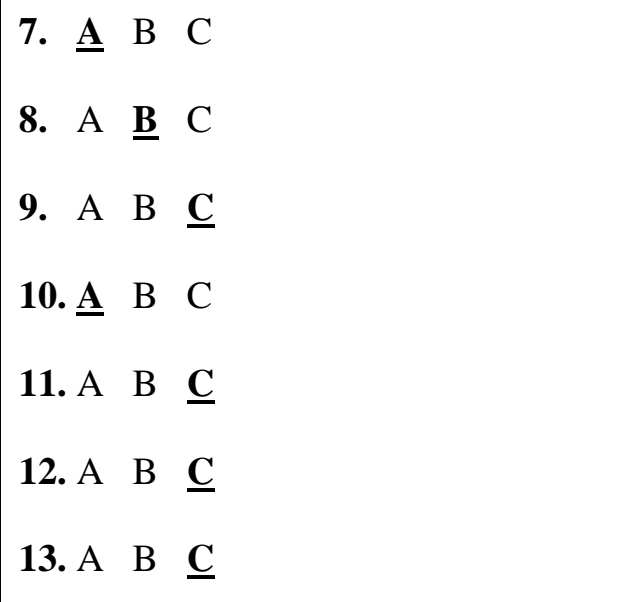 \\
\hline \multicolumn{3}{|c|}{ PART 3} \\
\hline \multicolumn{3}{|l|}{21.} \\
\hline \multicolumn{3}{|l|}{22.} \\
\hline \multicolumn{3}{|l|}{23.} \\
\hline \multicolumn{3}{|l|}{24.} \\
\hline \multicolumn{3}{|l|}{25.} \\
\hline \multicolumn{3}{|l|}{26.} \\
\hline \multicolumn{3}{|l|}{27.} \\
\hline & & TOTAL SCORE: 20/20 \\
\hline
\end{tabular}




\section{PART 3:}

\section{Scenario: HOMEWORK}

You didn't turn in your homework assignment on the day it was due because you missed that class. You would like to see if you could still hand it in. You go to your teacher's office.

You: (knock on the door)

Teacher: Yes, come in.

OPTION 1: You: Hello, Mrs. Smith, I wanted to ask if I could turn my homework in. I understand if you can't or need to deduct points, it was my fault for not making the deadline.

OPTION 2: You: Hello, Mrs. Smith, I know I missed class, but I was wondering if I could still submit the homework?

\section{Scenario: GRADING TESTS}

You are a Graduate Assistant and you work for a college professor. He asks you to grade a lot of tests by tonight, but you can't do it.

Professor: Ok, so I'm going to need you to have those tests graded by this evening.

OPTION 1: You: Is it ok if I hand it in first thing tomorrow? I will be unable to give them a thorough and complete look by tonight, but I can assure a satisfactory job by tomorrow.

OPTION 2: You: I’m sorry sir/ma'm, but I have a big test to study for tonight. Would it be possible to get them to you by tomorrow evening?

\section{Scenario: CLOTHING STORE}

You go to the clothing store after work and you have to be home soon.

Salesperson: May I help you?

OPTION 1: You: Yes, I am looking for ....., do you have it?

OPTION 2: You: No, I’m just looking, thanks.

\section{Scenario: IN-LAWS COMING OVER}

Your in-laws are coming for dinner and they're expecting their favorite meal but you didn't find all the ingredients. You call them to say that you can’t have their favorite meal tonight.

Mother-in-law: Oh, I can't wait to try my favorite meal that you're cooking!

OPTION 1: You: I am really sorry about this, but the stor didn't have all the ingredients. Is there anything else I can cook for you?

OPTION 2: You: I'm sorry, but I couldn't find all the ingredients. Do you still want it or shall we try another dish?

\section{Scenario: DIRECTIONS}

You need directions to the nearest mall. You ask a police officer.

You: Excuse me, officer.

Police Officer: Yes, how can I help you?

OPTION 1: You: Could you tell me how to get to the nearest mall?

OPTION 2: You: Where is the nearest mall from here? 
19. Scenario: INVITATION

You and Tim are co-workers. Tim invites you out to lunch but you cannot come.

Tim: Do you want to grab lunch with me?

OPTION 1: You: Sorry Tim, I'd love to but I can't. Rain check?

OPTION 2: You: I would love to but I have to prepare for class. Tomorrow, perhaps?

\section{Scenario: CANCELED DINNER PARTY}

You forgot to call a friend to tell her that the dinner party was canceled and she has spent the whole day cooking something for it. You receive a phone call from her after the time that you were supposed to pick her up for the party.

Friend: Hey, where are you? Are you on your way?

OPTION 1: You: Oh my God! I am so sorry. I forgot to tell you that it was cancelled. I feel so awful. What are you doing now?

OPTION 2: You: Oh my! I'm sorry. The party got cancelled and I forgot to call you. I'm so sorry. We can still eat the dinner though! I don't want it to go to waste since you spent so much time on it. 
VERSION 3 - Answer Key

\begin{tabular}{|c|c|c|}
\hline & PART 1 & PART 2 \\
\hline $\begin{array}{l}\text { 1. } \square \text { Yes } \\
\text { 2. } \square \text { Yes } \\
\text { 3. } \square \text { Yes } \\
\text { 4. } \square \text { Yes } \\
\text { 5. } \square \text { Yes } \\
\text { 6. } \square \text { Yes }\end{array}$ & $\begin{array}{l}\square \text { No } \\
\square \text { No } \\
\square \text { No } \\
\square \text { No } \\
\square \text { No } \\
\square \text { No }\end{array}$ & 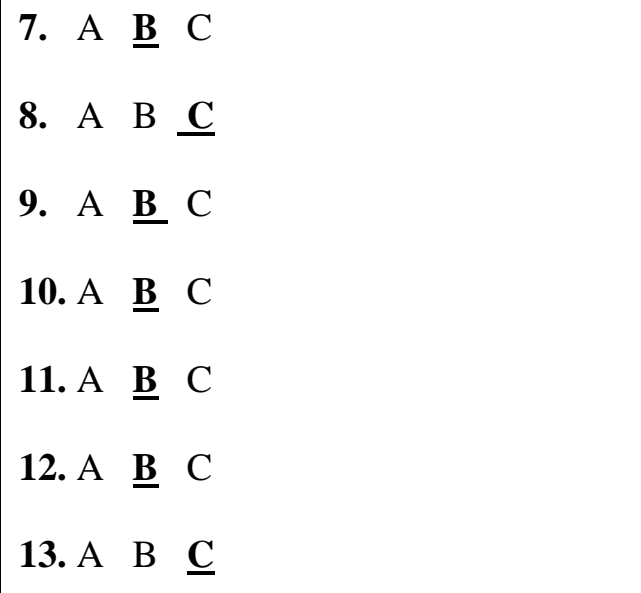 \\
\hline \multicolumn{3}{|c|}{ PART 3} \\
\hline \multicolumn{3}{|l|}{28.} \\
\hline \multicolumn{3}{|l|}{29.} \\
\hline \multicolumn{3}{|l|}{30.} \\
\hline \multicolumn{3}{|l|}{31.} \\
\hline \multicolumn{3}{|l|}{32.} \\
\hline \multicolumn{3}{|l|}{33.} \\
\hline \multicolumn{3}{|l|}{34.} \\
\hline & & TOTAL SCORE: 20/20 \\
\hline
\end{tabular}




\section{PART 3:}

14. Scenario: LECTURE EXPLANATION

Your professor was giving a very complicated lecture and you didn't do the reading beforehand so you had a hard time understanding it. You go up to him after class to ask for clarification on key points.

You: (knock on your professor's office door)

Teacher: Yes, come in.

OPTION 1: You: Hello, Mr. West, I was wondering if I could ask you some things about today's lecture, I got a little lost.

OPTION 2: You: Hello, Mr. West, I have some questions about today's lecture. Do you have time right now?

15. Scenario: WORK

Your boss asks you to come in to work on your day off but you had already made other plans.

Boss: I can count on you to come in and help me do this, right?

OPTION 1: You: I wish I could, but I have personal obligations then.

OPTION 2: You: Sir, I'm sorry, but I've already made plans. Is there any other way I can make it up?

\section{Scenario: COFFEE SHOP}

You go to the coffee shop to get your favorite drink but you are in a very big hurry and the clerk Emily is moving very slowly.

Emily: May I help you?

OPTION 1: You: I would like..... And I hate to sound rude, but could I get it quickly?

OPTION 2: You: Yes, may I have a small coffee to go, please?

\section{Scenario: MISSING HANDOUT}

You are a student giving a presentation in front of your classmates. Everything is going well and you realize that you forgot a very important handout you were going to give to everyone.

Teacher: Is there a handout that goes along with this?

OPTION 1: You: There is, but I foolishly forgot it. I can send everyone an e-mail and bring hard copies next time.

OPTION 2: You: Yes, there is, but I can't find it. May I go get it or shall I start? I can give everyone a copy later if that's ok?

\section{Scenario: INFORMATION}

You have a job interview and you can’t find the location of the room. You stop and ask a secretary who works there.

You: Excuse me.

Secretary: Yes, may I help you?

OPTION 1: You: Can you tell me where.... is?

OPTION 2: You: I’m trying to find Mr. Jones' office. Do you know where it is?

\section{Scenario: INVITATION}

Your neighbor invites you to his house to watch a football game but you hate football. 
Michael: Hey, do you want to come over and watch the football game with me and my family tonight?

OPTION 1: You: Sure, maybe you can show me why you love it so much.

OPTION 2: You: Sure, but I can only stay for a little bit.

\section{Scenario: LATE ASSIGNMENT}

You have turned in a project for your class late for the second time. Your teacher had already given you one chance of forgiveness and you need to explain to him why you deserve another chance.

Teacher: I'm not going to accept this assignment because I've already given you a chance.

OPTION 1: You: That is more than fair. Is there anything else I can do to help my grade?

OPTION 2: You: I understand, but I was just wondering if I could have another chance. I know I should have done it earlier. Sorry. 


\title{
W. WestVirginiaUniversity. \\ Office of Research Compliance
}

\section{CONSENT AND INFORMATION FORM}

\author{
INFORMED CONSENT DOCUMENT
}

Principal Investigator: Jiang, Xiangying

Department: $\quad$ ARTS \& SCIENCES - Foreign Language

Tracking Number: $\quad \mathrm{H}-23457$

Study Title: Bringing Pragmatics into the ESL Classroom

Co-Investigator(s): Bucher B Da Silva, Tahnee.

\section{Sponsor}

\section{Contact Persons}

In the event you experience any side effects or injury related to this research, or if you have any questions, concerns, or complaints about this research, you should contact Tahnee Bucher B. da Silva at (304) 376-9596 or by e-mail at tbucherb@mix.wvu.edu.

For information regarding your rights as a research subject, you may contact the Office of Research Compliance at 304/293-7073.

\section{Introduction}

In addition if you would like to discuss problems, concerns, have suggestions related to research, or would like to offer input about the research, contact the Office of 
Research Integrity and Compliance at (304) 293-7073.You, have been asked to participate in this research study, which has been explained to you by Tahnee Bucher B. da Silva. This study is being conducted by Tahnee Bucher B. da Silva, a graduate student and teaching assistant in the Department of Foreign Languages at West Virginia University. This research is being conducted to fulfill the requirements for a Master's Degree in TESOL in the Department of Foreign Languages at West Virginia University, under the supervision of Dr. Xiangying Jiang, an assistant professor in the Eberly College of Arts and Sciences.

\section{Purposes of the Study}

The purpose of this study is to learn more about ESL learners' ability to use English appropriately. WVU expects to enroll a total of approximately forty subjects at all sites to participate in this study.

\section{Description of Procedures}

This study involves classroom practices and procedures that will take approximately 8 hours in total for you to complete. You will first be asked to complete a brief questionnaire related to your English learning experience and take a language test. Then you will receive four hours of instruction. After the instruction, you will take another test twice within an interval of one week.

\section{Risks and Discomforts}

There are no known or expected risks from participating in this study.

\section{Alternatives}

You do not have to participate in this study.

There aren't other alternatives.

\section{Benefits}

During the process, you'll have an opportunity to learn to communicate more 
effectively in English. Information obtained from this study could be beneficial in understanding the communicative skills and intercultural competence of ESL learners.

\section{Financial Considerations}

You will not get paid for participating in this study. There are no special fees for taking part in this research project, and all the materials necessary for the study will be provided by the researcher.

\section{Confidentiality}

Your performance in this project will be kept confidential. All data will be reported as group averages and no individual information will be reported. You can decide to sign or not to sign this authorization section. However, if you choose not to sign this authorization, you will not be able to take part in the research study. Whatever choice you make about this research study, it will not have an effect on your class standing at West Virginia University.

\section{Voluntary Participation}

Your participation is completely voluntary. You must be 18 years of age or older to participate. You may discontinue at any time. You may skip any question if you want. Your class standing will not be affected if you decide either not to participate or to withdraw. West Virginia University's Institutional Review Board acknowledgement of this project is on file. In the event new information becomes available that may affect your willingness to participate in this study, this information will be given to you so that you can make an informed decision about whether or not to continue your participation. You have been given the opportunity to ask questions about the research, and you have received answers concerning areas you did not understand. 
Upon signing this form, you will receive a copy.

I willingly consent to participate in this research.

$\begin{array}{ll}\text { Signature of Subject or } & \text { Printed Name } \\ & \text { Time Subjects Legal Representative }\end{array}$

The participant has had the opportunity to have questions addressed. The participant willingly agrees to be in the study. 


\section{APPENDIX J: SAMPLE SYLLABUS}

The following syllabus is derived from the results of a research project which examined ESL learners’ ability to use English appropriately. The findings helped understand the communicative skills and intercultural competence of ESL learners and demonstrated that instruction in the area of pragmatics is not only important but also necessary at all levels of language proficiency. Since pragmatics has not been the primary focus of other classes, this course, entitled “The Secret Rules of English: Learning Pragmatics”, was designed to be an elective course for low-intermediate to advanced students in the Intensive English Program at West Virginia University, and although it has not been taught yet, its mission and policies reflect the institution's.

This course aims primarily to develop students’ conversation skills; therefore most of the formal and informal assessment is spoken and based on their performance in role-plays, voicemail recordings, interaction with their peers and instructor, and active participation in class. Since this is a fairly different course both in terms of content, tasks, and methods of assessment, students will have extended practice in and outside of class and will receive feedback constantly. The assessment tools are consistent with what is done in class as well.

In addition, the course content was set up in such a way that students move toward more complex tasks in a logical manner. Thus, during the first five weeks of the semester, the activities focus on raising students’ awareness of pragmatic differences across languages, and students will be involved in discussions in which they learn to explain why, when, how, and where certain linguistic structures are preferred over others. The second part of the course will focus not only on recognizing pragmatic infelicities but also on producing socially appropriate language. Students will then work on speech acts, conversational management, conversational openings and closings, conversational implicatures, and sociolinguistic aspects of language use.

Based on the fact that second language speakers may be perceived as rude if they are not aware of the sociolinguistic rules governing language use (e.g., what to say to whom and when), the ultimate goal of this course is to help ESL learners communicate more effectively in order to avoid cross-cultural miscommunication. The objective is not to make students sound native-like, but rather to give them the linguistic tools so that they can make conscious choices about their spoken and written interactions in the target language. 


\section{WVU Intensive English Program}

\section{The Secret Rules of English: Learning Pragmatics}

Semester: Fall 2012

Time: TR 2:30-3:45

Room: TBA

Instructor: Tahnee Bucher

Office: 302 Eiesland Hall

Office Hours: MWF 12:20-1:20 and by appointment

E-mail: tbucherb@mix.wvu.edu/tahneebucher@gmail.com

\section{Course Description}

Learning a language entails more than just learning its sound systems, syntax, morphology, lexicon, and semantics. In order to become communicatively competent in a second language, students also need to know pragmatics, or the way in which we use language in context. This course is designed to increase ESL learners' pragmatic competence (knowledge of speech acts and speech functions and ability to use language appropriately according to context) in order to help them communicate more effectively in English. In this course, students will receive formal and explicit instruction in pragmatics through awareness and production activities aimed at developing their linguistic and sociolinguistic skills and intercultural competence.

\section{Learning Outcomes}

By the end of the course, students will be able to...

*... interpret the input they hear, in actual comprehension ("What does this mean?") and interpretation ("How is this used?" or "What does a speaker who says this hope to accomplish?”).

*... explain when and why certain linguistic practices take place.

*... match utterances with contexts in which they are appropriate.

* ... identify pragmatic infelicities in video-taped scenarios and in written situations.

*... recognize and supply missing speech acts and semantic formulas.

*... vary the degree of formality (from very formal to very casual) of language depending on the context.

*... discuss their perceptions of the language and speakers of that language based on the linguistic choices they make.

*... make conscious choices about their spoken and written interactions in the target language. 


\section{Course Materials}

- No textbook is required for this course. The instructor will provide all the materials, and you are expected to keep them organized in a file or a binder.

- Class notebook that you are required to bring for each class to make some notes or class tasks.

\section{Recommended Texts:}

Kehe, D., \& Kehe, P. D. (2009). Conversation strategies. $2^{\text {nd }}$ ed. Vermont: Pro Lingua Associates.

Wall, A. P. (1998). Say it naturally 1: Verbal strategies for authentic communication. $2^{\text {nd }}$ ed. Boston: Heinle\&Heinle.

Wall, A. P. (1998). Say it naturally 2: Verbal strategies for authentic communication. $2^{\text {nd }}$ ed. Orlando, FL: Harcourt Brace \& Company.

\section{$\underline{\text { Course Policies }}$}

Attendance: Attendance will be taken daily, and regular class attendance is required to be successful in this class. You are expected to attend all classes. Absence from class for any reason will give you an absence for that day. There are no excused absences. More than 5 absences in this course will lower your grade by half a point for each additional absence. For example, a student with 6 absences will have a B grade lowered to a $\mathrm{C}+$. In addition, three tardies (late arrivals) equal one absence. Be on time!

Homework: Homework (and other types of graded work-assignments) is accepted only on or before the due date. If you are absent from class, you are responsible for making arrangements to have your work handed in on time and to find out about the work you missed in class, including any homework. An absence is not an excuse for not doing the work!

Classroom Civility: This is a class in which all students are expected to actively participate, to express different viewpoints, to share aspects of their own culture, to give opinions, and to practice speaking in a variety of social situations. Therefore, showing disrespect of any kind and poor manners toward the instructor and other students will not be tolerated and may result in removal from class or any other disciplinary action at the instructor's discretion.

Cell Phone Use: Cell phones and other electronic devices must be turned off during class. You may not answer, text or receive phone calls during class.

Social Justice Statement: WVU is committed to social justice. The instructor of this course concurs with such a commitment and intends to maintain a positive learning environment based upon mutual respect, non-discrimination, and open communication. Our University does not 
discriminate on the basis of race, sex, age, disability, veteran status, religion, sexual orientation, color, or national origin. Any suggestions concerning the enhancement of this environment will be appreciated and given serious consideration. If you are a person with a disability and anticipate needing any type of accommodation in order to participate in this class, please advise me and make appropriate arrangements with DISABILITY SERVICES (304 293-6700).

Academic Integrity: The integrity of the classes offered by any academic institution solidifies the foundation of its mission and cannot be sacrificed to expediency, ignorance, or blatant fraud. Therefore, I will enforce rigorous standards of academic integrity in all aspects and assignments of this course. For the detailed policy of West Virginia University regarding the definitions of acts considered to fall under academic dishonesty and possible ensuing sanctions, please see the Student Conduct Code at http://studentlife.wvu.edu/studentconductcode.html. Should you have any questions about possibly improper research citations or references, or any other activity that may be interpreted as an attempt at academic dishonesty, please see me before the assignment is due to discuss the matter.

\section{Course Requirements}

Participation: Participation includes, but is not limited to: 1) your presence in the classroom, 2) your willingness to respond to questions or to offer relevant opinions, 3) your contribution to pair and group activities, and 4) your general attitude toward your peers and the instructor. In addition, since most of the assessment in this class will be spoken, not written, you will be responsible (and expected) to actively participate during each class period. Your active participation will contribute to your final grade.

Homework: In order to actively participate in the class, it is also necessary to read all assigned texts and to do all of the homework assigned by the instructor.

$\Rightarrow$ Observation of natural language use: This exercise will count as part of your homework grade. During week 4 of the semester you will be required to go to Starbucks, to the Mountainlair, or to stay in the IEP lounge or in the secretary's office to observe the language use going on. You may also observe language use in other places outside of campus. Following the guidelines that will be given prior to that week, you will note, among other things, how people greet each other, how they take leave of each other, how they ask for things, etc. The examples you write down will be discussed later in class.

Role-Plays: Throughout the semester students will have to perform role-plays in pairs and in groups to apply their knowledge of pragmatics in real-world situations. Some topics/situations will be given in advance and some will be done in class without previous notice.

Voicemail Recording: Students will have to record a voicemail in order to practice leaving a brief phone message in English. 
Quizzes: Scheduled quizzes of approximately 15-20 minutes will be given throughout the semester. No make-up quizzes will be given. The lowest grade that you receive will be dropped in the final tally of grades.

Writing Assignment: Students will be asked to write an e-mail to an IEP instructor as part of their final grade by the end of the semester. Directions will be provided at mid-semester.

Exams: There will be two in-class examinations, a midterm exam on Thursday, October $4^{\text {th }}$, and a comprehensive final exam on Tuesday, December $4^{\text {th }}$, to check students' comprehension and production of socially appropriate language.

\section{Grading}

\begin{tabular}{|ll|ll|}
\hline \multicolumn{2}{|l|}{ Course Grade Percentages } & \multicolumn{2}{l|}{ Final Grading System } \\
\hline Participation & $20 \%$ & A & $90 \%-100 \%$ \\
\hline Homework & $10 \%$ & B & $80 \%-89 \%$ \\
\hline Role-Plays & $20 \%$ & C & $70 \%-79 \%$ \\
\hline Voicemail Recording & $5 \%$ & D & $60 \%-69 \%$ \\
\hline Quizzes & $15 \%$ & F & $59 \%$ or below \\
\hline Writing Assignment & $5 \%$ & & \\
\hline Exams & $25 \%$ & & \\
\hline \multicolumn{2}{|l|}{} \\
\hline
\end{tabular}


Fall 2012

\section{The Secret Rules of English: Learning Pragmatics}

\begin{tabular}{|c|c|c|}
\hline Week & Topics & $\begin{array}{c}\text { Graded } \\
\text { Assignment: }\end{array}$ \\
\hline Week 1 (08/21 and 08/23) & $\begin{array}{l}\text { Let's talk about the Secret Rules of } \\
\text { Languages: How speakers do things with } \\
\text { words } \\
\text { - } \\
\text { - } \text { Sociocultural Norms } \\
\quad \text { Prganizational Competence and } \\
\quad \text { Pragmatic Competence }\end{array}$ & \\
\hline Week $2(08 / 28$ and 08/30) & $\begin{aligned} & \text { Language and Culture } \\
& \text { - } \text { Language Functions } \\
& \text { - } \text { Universal Speech Acts } \\
& \text { - } \text { Appropriateness } \\
& \text { - } \text { Face-Threatening Acts } \\
& \text { - } \text { Building awareness of second } \\
& \text { language sociocultural norms }\end{aligned}$ & \\
\hline Week 3 (09/04 and 09/06) & $\begin{array}{ll}\text { - } & \text { Exploring prior impressions of } \\
\text { speakers } \\
\text { - } \quad \text { Native x non-native speakers }\end{array}$ & Quiz \#1 (09/04) \\
\hline Week $4(09 / 11$ and 09/13) & $\begin{array}{l}\text { Video: TV Episode - "Friends" } \\
\text { What to say to whom and when }\end{array}$ & $\begin{array}{l}\text { Observe natural } \\
\text { language use. }\end{array}$ \\
\hline Week 5 (09/18 and 09/20) & $\begin{array}{ll}\text { - } & \text { Discussion of observation } \\
\text { - } & \text { Conversational management } \\
\text { (mechanics of conversation, such as } \\
\text { turn taking, active listening, relevant } \\
\text { short responses, use of hesitation } \\
\text { markers) }\end{array}$ & \\
\hline Week 6 (09/25 and 09/27) & $\begin{array}{ll}\text { - } & \text { Greeting people and responding } \\
\text { - } & \text { Making and responding to } \\
& \text { introductions } \\
\text { - } & \text { Saying good-bye }\end{array}$ & $\begin{array}{l}\text { Role-Play \#1 } \\
(09 / 27)\end{array}$ \\
\hline Week 7 (10/02 and 10/04) & $\begin{array}{l}\text { - Using the telephone: beginning and } \\
\text { ending a phone call; leaving a } \\
\text { message. }\end{array}$ & $\begin{array}{l}\text { Mid-term exam } \\
(10 / 04)\end{array}$ \\
\hline Week 8 (10/09 and 10/11) & $\begin{array}{ll}- & \text { Asking for information } \\
\text { - } & \text { Giving directions and instructions }\end{array}$ & \\
\hline Week 9 (10/16 and 10/18) & $\begin{array}{ll}\text { - } & \text { Making suggestions and giving advice } \\
\text { - } & \text { Giving compliments }\end{array}$ & $\begin{array}{l}\text { Role-Play \#2 } \\
(10 / 18) \\
\text { Voicemail } \\
\text { Recording by } \\
10 / 18\end{array}$ \\
\hline Week $10(10 / 23$ and 10/25) & - $\quad$ Thanking people and responding to & Quiz \#2 (10/25) \\
\hline
\end{tabular}




\begin{tabular}{|c|c|c|}
\hline & $\begin{array}{l}\text { thanks } \\
\text { - } \quad \text { Making, accepting, and declining } \\
\text { invitations }\end{array}$ & \\
\hline Week 11 (10/30 and 11/1) & - $\quad$ Making requests and responding & $\begin{array}{l}\text { Role-Play \#3 } \\
(11 / 01)\end{array}$ \\
\hline Week $12(11 / 06$ and 11/08) & - $\quad$ Apologizing and responding & \\
\hline Week 13 (11/13 and 11/15) & $\begin{array}{l}\text { - } \begin{array}{l}\text { Practice writing an e-mail to an } \\
\text { instructor }\end{array} \\
\end{array}$ & Quiz \#3 (11/15) \\
\hline $\begin{array}{l}\text { Thanksgiving Break } \\
(11 / 20 \text { and } 11 / 22)\end{array}$ & --- & --- \\
\hline Week $14(11 / 27$ and 11/29) & $\begin{aligned} & \text { Conversational Implicatures } \\
&- \text { Conventional } \\
&- \text { Non-conventional } \\
&\end{aligned}$ & $\begin{array}{l}\text { Writing } \\
\text { Assignment by } \\
11 / 29 \\
\end{array}$ \\
\hline Week 15 (12/04 and 12/06) & Using and interpreting body language & $\begin{array}{l}\text { Final Exam } \\
(12 / 04)\end{array}$ \\
\hline Week 16: no IEP Classes & --- & --- \\
\hline
\end{tabular}

